
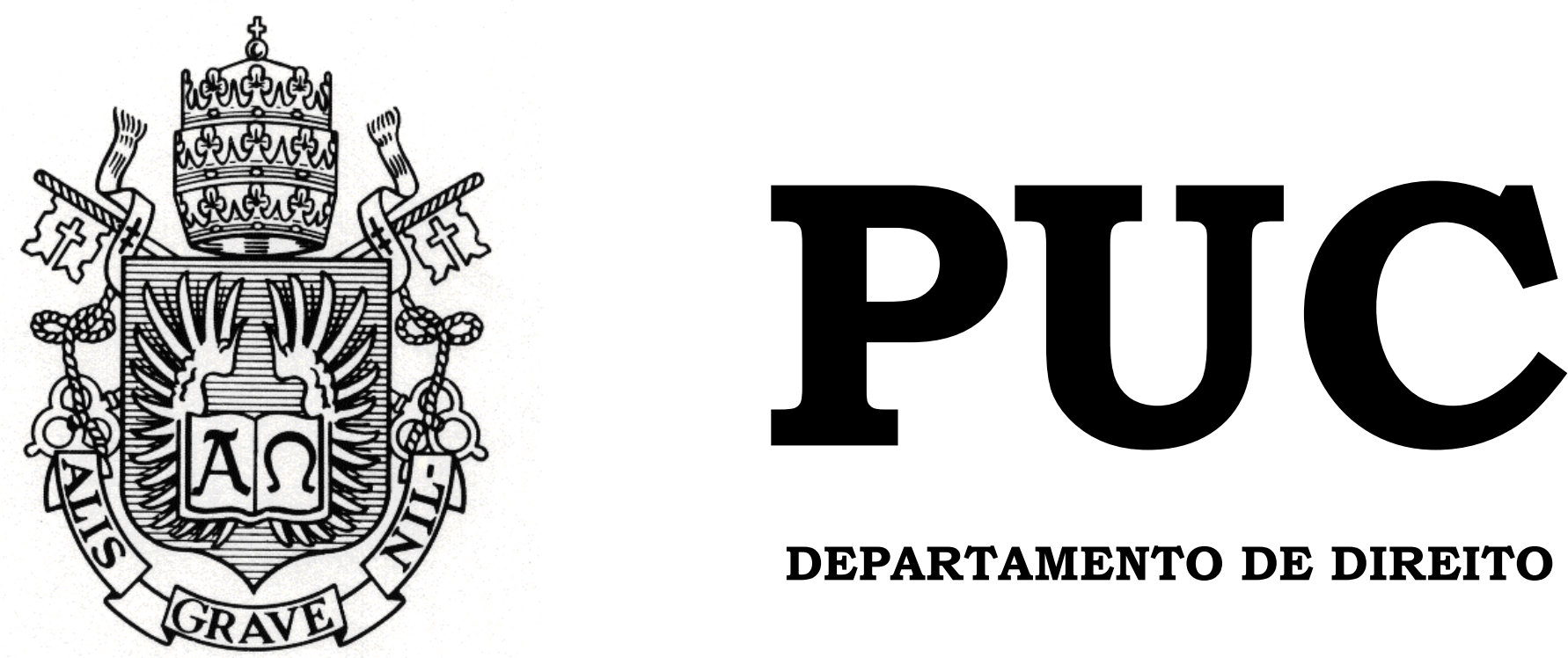

DEPARTAMENTO DE DIREITO

\title{
Aspectos da responsabilidade dos administradores de fundos de pensão
}

por

Igor Bernardo Souza da Silva

ORIENTADOR(A): Norma Jonssen Parente

2016.1

PONTIFÍCIA UNIVERSIDADE CATÓLICA DO RIO DE JANEIRO

RUA MARQUÊS DE SÃO VICENTE, 225 - CEP 22453-900

RIO DE JANEIRO - BRASIL 


\title{
Aspectos da responsabilidade dos administradores de fundos de pensão
}

\author{
por
}

Igor Bernardo Souza da Silva

Monografia

apresentada

ao

Departamento de Direito da Pontifícia Universidade Católica do Rio de Janeiro (PUC-Rio) para a obtenção do Título de Bacharel em Direito.

Orientador(a): Norma Jonssen Parente 


\section{Agradecimentos}

Durante uma aula de Antropologia, fui indagado sobre o significado da palavra gratidão e foi uma grande surpresa, para mim mesmo, não saber responder. Agora, nestas poucas linhas, tento exprimir o que eu não soube dizer em sala de aula.

Gratidão é uma reação, é quando a generosidade de outrem te invade de tal forma que não sobram meios para retribuir a não ser dando o que se tem de mais valioso: o sentimento.

Por isso, quero declarar a minha mais sincera gratidão à Eliane Souza da Silva, minha mãe, que durante esses cinco anos de faculdade acordava às $4 \mathrm{~h}$ para passar a minha roupa, fazer o meu café e me desejar um bom dia na faculdade; ao Joaquim Bernardo da Silva Filho, que, além de pai, é meu melhor amigo; à Raquel Pinto de Lira do Nascimento, por adocicar a minha vida; à Aracele Queiroz e Jonathas Queiroz, por toda a caminhada que fizemos juntos; ao Nilson Queiroz e Maria das Graças, por tantas conversas e conselhos; à Dona Ana Nascimento e Seu Lira Nascimento, por todo o apoio e carinho.

Também quero declarar a minha gratidão à Norma Jonssen Parente, que, para mim, é muito mais que uma orientadora. É também uma amiga, uma grande pessoa e um exemplo a ser seguido.

Por último, mas não menos significativo, gostaria de declarar a minha gratidão à Claudia de Azeredo Santos e ao Leonardo Ugatti, que muito me ensinaram sobre Direito e amizade. 


\section{Resumo}

O presente trabalho tem como objetivo analisar aspectos da responsabilidade dos administradores de Fundos de Pensão em diversos âmbitos do Direito, quais sejam: civil, administrativo, penal e tributário. Para a consecução desse estudo, serão abordadas lições desenvolvidas para administradores de outras entidades, mas que, em respeito a uma leitura sistemática do ordenamento jurídico brasileiro, devem ser trazidas para a avaliação da conduta dos administradores de Fundos de Pensão.

Palavras-chave: fundos de pensão, administrador, responsabilidade 


\section{SUMÁRIO}

CAPÍTULO 1 - INTRODUÇÃO.............................................................................9

1.1. A escolha do tema e sua relevância...............................................................9

1.2. Metodologia utilizada para o estudo do tema...........................................11

1.3. A escolha do tema......................................................................................11

1.4. Uma breve introdução ao estudo dos Fundos de Pensão.......................12

1.4.1. Diferenças entre previdência complementar e previdência

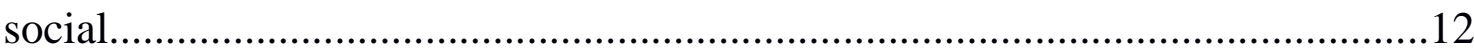

1.4.2. Diferenças entre regime de previdência aberto e fechado................13

1.4.3. Do vínculo entre Fundos de Pensão, patrocinadores e

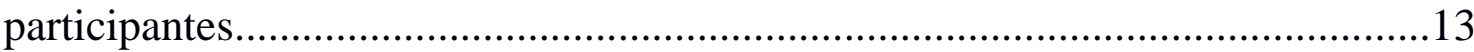

1.4.4. Do vínculo entre Fundos de Pensão, instituidores e

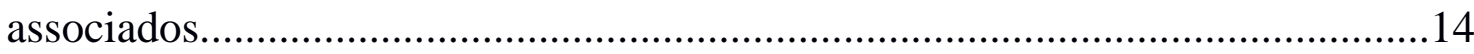

1.4.5. Natureza dos Fundos de Pensão.......................................................14

1.4.6. Destinação dos resultados nos Fundos de Pensão.............................15

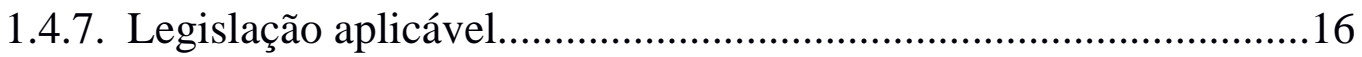

1.4.8. Os Fundos de Pensão e seus planos de benefícios...........................16

1.4.9. Fiscalização da PREVIC..................................................................17

1.4.10. A estrutura organizacional dos Fundos de Pensão............................17

1.5. Delimitação do tema................................................................................................20

CAPÍTULO 2 - PLANOS DE BENEFÍCIOS ADMINISTRADOS POR

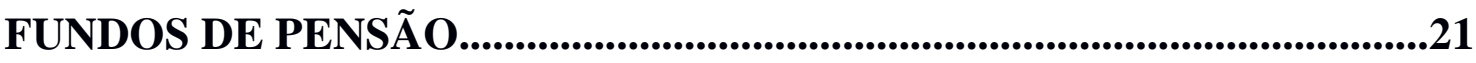

2.1. Do objetivo dos Fundos de Pensão e seu vínculo com os participantes.............................................................................................................................21

2.2. Relação entre Fundos de Pensão e planos de benefícios............................22

2.2.1. Fundo de Pensão como aclimatação do trust ......................................22

2.2.2. Planos de benefícios como condomínios............................................24

2.2.3. O surgimento dos fundos de investimento........................................26

2.2.4. A figura do administrador nos condomínios......................................27 
2.2.5. O problema da representatividade dos fundos de pensão. .28

2.3. A independência com relação aos benefícios do INSS...........................29

2.4. A identidade própria dos planos de benefícios........................................29

2.5. Planos de benefícios e as diretrizes estabelecidas pelo CMN................30

2.6. Fiscalização das aplicações dos recursos de planos de benefícios..........................................................................................31

2.7. Modalidades dos planos de benefícios...............................................31

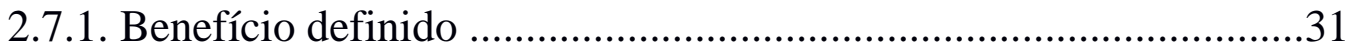

2.7.2 Contribuição definida ......................................................... 33

2.7.3. Contribuição variável............................................................33

CAPÍTULO 3 - TRIBUTAÇÃO DOS PLANOS DE PREVIDÊNCIA COMPLEMENTAR................................................................................................35

3.1. Quanto aos Fundos de Pensão..................................................................35

3.1.1. Da ocorrência ou não do fato gerador..........................................35

3.1.1.1. incidência quanto às tributações: inocorrência de acréscimo

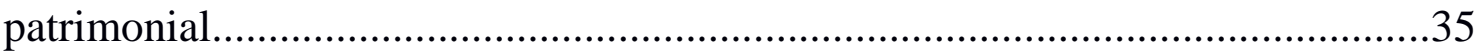

3.1.1.2 Incidência quanto aos resultados positivos das aplicações de recursos dos planos de benefícios .36

3.1.1.3. Da existência da aquisição de disponibilidade .38

3.1.2. Da isenção do Imposto de Renda para Fundos de Pensão e imunidade tributária de tais entidades. .39

3.1.3. Regime aplicável para apuração do lucro nos Fundos de Pensão. .41

3.2. Quanto aos participantes e assistidos.................................................43

3.3. A responsabilidade tributária dos administradores de Fundos de Pensão..................................................................................................45

CAPÍTULO 4 - ADMINISTRAÇÃO DOS FUNDOS DE PENSÃO............46

4.1. Noções gerais..................................................................................46

4.1.1. Natureza jurídica dos Fundos de Pensão.....................................46

4.1.2. Fundações ou sociedades civis...............................................47 


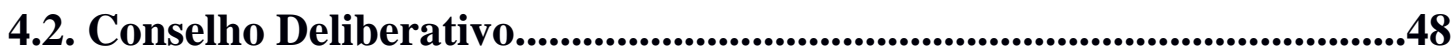

4.3. Diretoria Executiva.............................................................................................49

4.4. Conselho Fiscal..........................................................................................50

CAPÍTULO 5 - RESPONSABILIDADE DOS ADMINISTRADORES DE FUNDOS DE PENSÃO.....................................................................................52

5.1. Da aplicação dos deveres fiduciários dos administradores de sociedades anônimas à análise da responsabilidade dos administradores de Fundos de Pensão .52

5.2. Os deveres fiduciários dos administradores de sociedades anônimas...............................................................................................................53

5.2.1. Dever de Diligência........................................................................53

5.2.2. Dever de Lealdade.........................................................................54

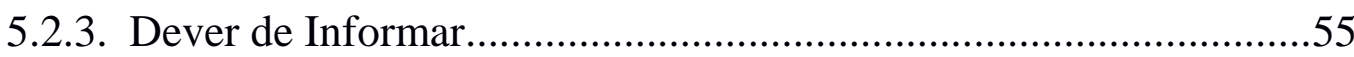

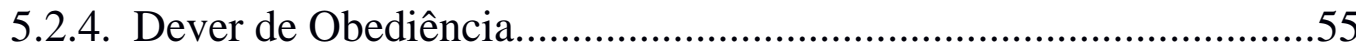

5.3. Transações entre partes relacionadas no âmbito dos Fundos de Pensão..................................................................................................................................56

5.3.1. As transações entre partes relacionadas e o conflito de

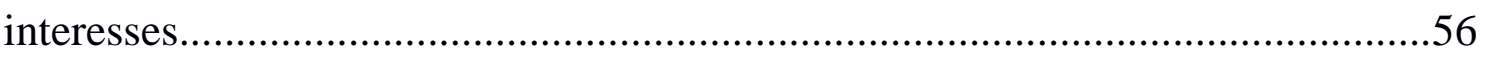

5.3.2. As transações entre partes relacionadas e o Dever de Diligência .57

5.4. Fundamentos da responsabilidade civil...................................................58

5.4.1. Casos de responsabilidade subjetiva.................................................58

5.4.2. Casos de responsabilidade presumida............................................64

5.4.3. Casos de responsabilidade objetiva.................................................64

5.5. Fundamentos da responsabilidade administrativa....................................67

5.6. Intervenção e liquidação extrajudiciais.........................................................73

CAPÍTULO 6 - OBRIGAÇÕES DAS EMPRESAS PATROCINADORAS E DAS ENTIDADES ASSOCIATIVAS INSTITUIDORA DOS

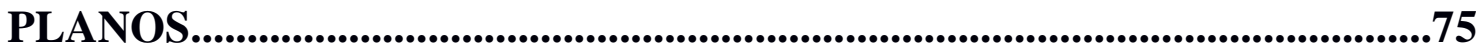

6.1. Obrigações das empresas patrocinadoras..................................................75 
6.1.1. Obrigações assumidas perante o Fundo de Pensão...........................75

6.1.2. Responsabilidade do patrocinador pela resilição do contrato. .76

6.1.3. A aplicação dos deveres fiduciários dos administradores de Fundos de Pensão aos patrocinadores de Fundos de Pensão................................................78

6.2. Obrigações das entidades associativas autônomas......................................79 CAPÍTULO 7 - DOS LIMITES QUANTITATIVOS DO CMN PARA

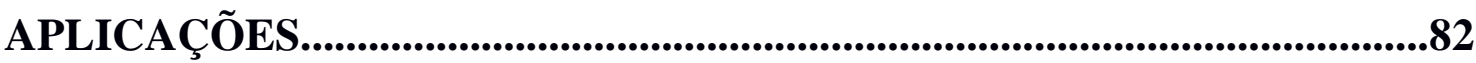

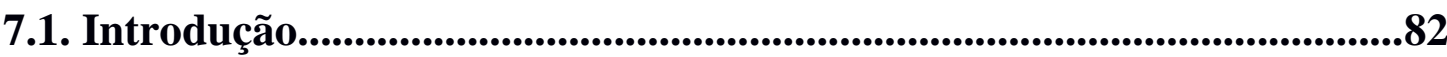

7.2. De alocação por investimento..........................................................................82

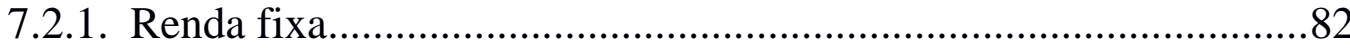

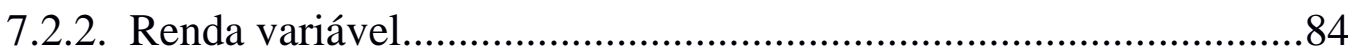

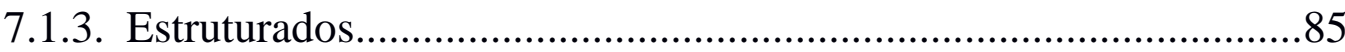

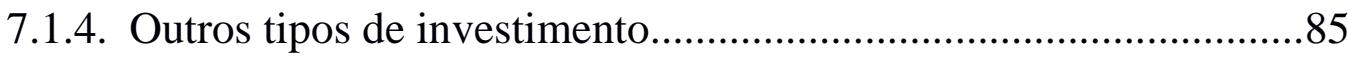

7.3. De alocação por emissor..................................................................................86

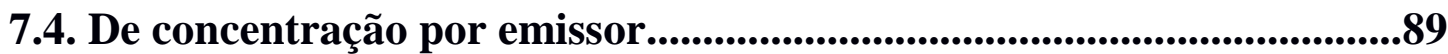

7.5. De concentração por investimento................................................................92

7.6. Desenquadramento passivo.............................................................................92

7.7. Vedações aos Fundos de Pensão.....................................................................93

CAPÍTULO 8 - LIMITES DO PODER REGULAMENTAR.........................96

8.1. A questão da sanção penal por descumprimento da Resolução CMN

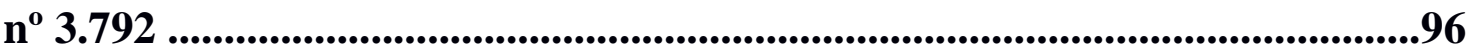

8.1.1. A imprecisão do tipo penal de gestão temerária.............................96

8.1.2. A busca por parâmetros...................................................................97

8.1.3. Conceito de temeridade..................................................................98

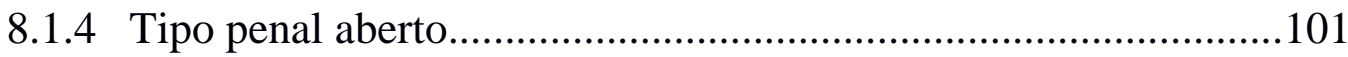

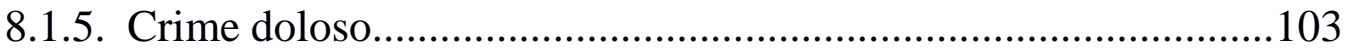

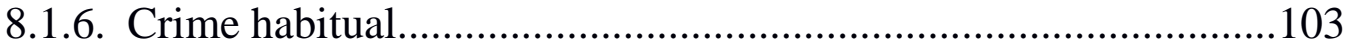

8.1.7. Da configuração de indícios..........................................................104

8.2. São válidos os limites instituídos pela Resolução CMN $\mathbf{n}^{0}$ 


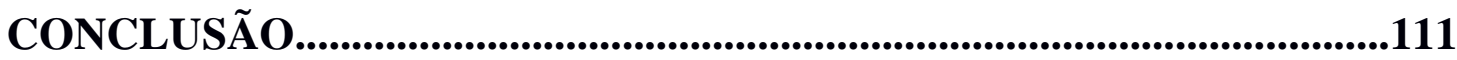

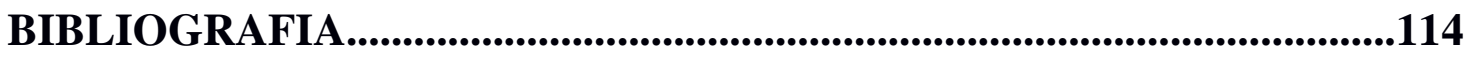




\section{CAPÍTULO 1 - INTRODUÇÃO}

\subsection{Colocação da questão e sua relevância}

O Sistema de Previdência Complementar Brasileiro dispunha em janeiro de 2015 de recursos que, divididos dentre as 317 Entidades Fechadas de Previdência Complementar (que serão referidas neste trabalho doravante apenas como "Fundos de Pensão"), totalizavam cerca de 702 bilhões de reais em ativos - valor que corresponde a 12,7\% do PIB brasileiro - desses, 673 bilhões investidos, conforme dados estatísticos da Associação Brasileira das Entidades Fechadas de Previdência Complementar ${ }^{1}$ (“Abrapp”).

A importância dos Fundos de Pensão não se limita à supressão do déficit da previdência comum, tais entidades, graças ao seu volume de recursos e de investimentos praticados em diversos setores produtivos, também contribuem para a movimentação da economia brasileira.

Os Fundos de Pensão acumularam, de 2006 a 2015, uma rentabilidade de $196,04 \%$, todavia parecem estar passando por um período de dificuldades: a rentabilidade em 2015 é a pior em 7 anos: $0,45 \%{ }^{2}$. A título de exemplo, o Fundo de Pensão do Banco do Brasil ("Previ"), maior Fundo de Pensão da América Latina, registrou no referido ano um déficit de 13 bilhões de reais ${ }^{3}$. Notícias veiculadas em jornais sugerem que o motivo

1 ABRAPP. Banco de dados. Disponível em: <http://www.abrapp.org.br/Consolidados/Consolidado\%20Estat\%C3\%ADstico_01_2015. pdf $>$. Acesso em 15.06.2015.

2 ABRAPP. Banco de dados. Disponível em:: <http://www.abrapp.org.br/Consolidados/Consolidado\%20Estat\%C3\%ADstico_01_2015. pdf> Acesso em 15.06.2015.

3 BÔAS, Bruno Villas. Fundo de pensão do Banco do Brasil registrou deficit de R\$ 13 bi em 2015. Folha de São Paulo. Disponível em: 
para o mau resultado dos fundos de pensão foi a aplicação de seus recursos em ativos duvidosos ${ }^{4}$.

A má administração dos planos de um Fundo de Pensão pode gerar aumento das contribuições de seus participantes e patrocinadores, reduzindo o salário e, consequentemente, a qualidade de vida de milhões de pessoas, ou, na pior das hipóteses, inviabilizar o pagamento do benefício ${ }^{5}$. Por isso, o estudo da responsabilidade dos administradores de tais entidades é de grande relevância.

A relação de fidúcia mantida entre os administradores dessas entidades e - não só os Fundos de Pensão, mas - todos os participantes dos planos administrados por elas, que contribuem com aportes de investimentos a serem geridos, implica a exigência de um padrão de conduta não previsto em legislação específica ${ }^{6}$.

Não obstante a importância dessas entidades, a doutrina jurídica tem pouco a oferecer no que concerne à interpretação das normas que regulam a sua atividade, em consequência disso, aumenta-se a incerteza no que concerne à correta atuação do setor ${ }^{7}$. Em razão disso, faz-se necessário colocar em exame a conduta dos administradores dessas entidades em suas funções e questionar sua adequação.

O objetivo deste estudo é alçar balizas para a atividade de administração de Fundos de Pensão, bem como discutir a abrangência de

$4 \quad<$ http://brasil.elpais.com/brasil/2015/05/28/economia/1432768510_780072.html>. Acesso em 15.06.2015.

${ }^{5}$ CASADO, José. Aparelhamento de fundos de pensão afeta 500 mil aposentados. O Gobo. Disponível em: <http://oglobo.globo.com/brasil/aparelhamento-de-fundos-depensao-afeta-500-mil-aposentados-18717904>. Acesso em 15.06.2015.

${ }^{6}$ DINIZ, Gustavo Saad. Responsabilidade do administrador de entidades fechadas de previdência complementar. Revista de Informação Legislativa. Brasília, jul/set 2011.Pág. 71-80.

${ }^{7}$ DINIZ, Gustavo Saad. Responsabilidade do administrador de entidades fechadas de previdência complementar. Revista de Informação Legislativa. Brasília, jul/set 2011.Pág. 71-80. 
sua responsabilidade, do ponto de vista administrativo, penal e civil, por eventuais danos que tais entidades venham a sofrer ou, simplesmente, por atos ilícitos que não causem danos às mesmas.

\subsection{Metodologia utilizada para o estudo do tema}

Este trabalho pautar-se-á em uma análise descritiva da responsabilidade do administrador à luz da atual legislação, levando em conta a produção doutrinária e jurisprudencial tanto em temas diretamente ligados à previdência complementar, quanto em temas afins que possam trazer algumas lições válidas para o nosso objeto de estudo.

Para uma análise completa do tema, serão incluídos nessa pesquisa alguns aspectos fundamentais dos fundos de pensão.

\subsection{A escolha do tema}

A ideia de estudar o tema surgiu através da análise dos limites de investimentos dos recursos dos fundos de pensão previstos na Resolução CMN 3.792, a dificuldade em encontrar materiais que abordassem de forma mais profunda a matéria despertou curiosidade no autor.

Devido à importância do papel dos administradores nos fundos de pensão, para os participantes de seus planos de benefícios e para a economia brasileira, resolveu-se realizar a presente pesquisa como forma de explorar o tema. 


\subsection{Uma breve introdução ao estudo das Entidades Fechadas de Previdência Complementar}

\subsubsection{Diferenças entre previdência complementar e previdência social}

Para estudar a responsabilidade dos administradores de fundos de pensão, o primeiro passo é conhecer as características particulares do nosso sistema de previdência complementar. Este capítulo destina-se a introduzir algumas noções básicas acerca do tema.

É importante observar que o regime de previdência complementar não se confunde com o regime geral de previdência social ou com os regimes próprios de previdência dos servidores públicos.

No regime geral de previdência social, os participantes contribuem com um valor que será utilizado para o pagamento do benefício aos assistidos para que, posteriormente, também tenha seu benefício pago com o dinheiro da contribuição de outros participantes. A previdência complementar, por outro lado, baseia-se na capitalização de recursos através das contribuições previdenciárias e nos rendimentos auferidos com a sua aplicação.

As principais características que distinguem a previdência complementar dos outros sistemas de previdência são: a filiação voluntária; a gestão privada; o regime contratual, pois as regras de elegibilidade, custeio, reajuste da aposentadoria, além do elenco de benefícios, vem previstas no regulamento do plano previdenciário; e, por último, o regime financeiro de capitalização ${ }^{8}$.

\footnotetext{
${ }^{8}$ Art. 202, da CRFB/88, e 18, da LC 109/2001.
} 


\subsubsection{Diferenças entre regime de previdência fechado e aberto}

O regime de previdência fechado é executado por Fundos de Pensão, sem fins lucrativos, diferentemente do regime de previdência aberto, no qual Entidades Abertas de Previdência Complementar ("Sociedades Seguradoras") o realizam essa atividade com fins lucrativos.

Além dos Fundos de Pensão se distinguirem das Sociedades Seguradoras pela inexistência de fins lucrativos, os planos daquelas também são exclusivos para funcionários das empresas patrocinadoras ou membros das associações instituidoras.

Por exemplo, um indivíduo sem vínculo empregatício com os Correios está impedido de participar dos planos de benefícios patrocinados pela empresa; por outro lado, nas Sociedades Seguradoras, qualquer um pode escolher um plano de benefícios e se filiar a ele.

Outra diferença fundamental as Sociedades Seguradores não se submetem à fiscalização da Superintendência de Seguros Privados ("SUSEP"); os Fundos de Pensão, por sua vez, submetem-se à supervisão da Superintendência Nacional de Previdência Complementar ("PREVIC").

Quanto à estrutura societária de ambos, os Fundos de Pensão se revestem da forma de fundações ou sociedades civis, as Sociedades Seguradoras, por sua vez, assumem a forma de sociedade anônima.

\subsubsection{Do vínculo entre Fundos de Pensão, patrocinadores e participantes}

Os Fundos de Pensão têm esse nome porque para fazer parte de um de seus planos de benefícios é necessário ter: (i) vínculo empregatício com a empresa patrocinadora do plano; ou (ii) ter vínculo associativo com a entidade associativa instituidora do plano. 
Define-se como "patrocinadora" a empresa que assume uma obrigação previdenciária autônoma por influência do Sistema Previdenciário Americano, no qual os planos de benefícios, em sua modalidade benefício definido, nasceram sob o patrocínio (sponsorship) dos empregadores ${ }^{9}$. Ou seja, eram eles que arcavam com a integralidade dos créditos devidos aos Fundo de Pensão.

No Brasil, não obstante haja a possibilidade de planos não contributivos, ou seja, planos financiados integralmente pelos empregadores, a regra geral é o "copatrocínio" por parte dos empregadores. Dessa forma, os empregadores financiam, via de regra, apenas parte do que é devido aos Fundo de Pensão.

\subsubsection{Do vínculo entre Fundos de Pensão, instituidores e associados}

As entidades associativas instituidoras, por outro lado, são pessoas jurídicas de caráter profissional, classista e setorial que assumem uma obrigação previdenciária autônoma perante ao Fundo de Pensão. Um exemplo desse tipo de plano é o OABPrev/SP.

Para poder instituir criar um Fundo de Pensão e instituir plano de benefícios, a entidade associativa deve preencher alguns requisitos que serão analisados pormenorizadamente no capítulo específico.

\subsubsection{Natureza dos Fundos de Pensão}

Além das características já mencionadas anteriormente, é importante destacar que os Fundos de Pensão têm natureza privada, porém sem fins lucrativos. Então, ainda que a empresa patrocinadora seja uma empresa pública, sua natureza será privada, pois o Fundo de Pensão não se confunde

\footnotetext{
${ }^{9}$ REIS, Adacir. Curso Básico de Previdência Complementar. Editora Revista dos Tribunais: 2012, São Paulo. P. 50.
} 
com a empresa patrocinadora, tendo, inclusive, limites rígidos para a aplicação de recursos na empresa patrocinadora, como se verá adiante.

Segundo o professor Arion Sayão Romita ${ }^{10}$, os Fundos de Pensão são "sociedades civis ou fundações que têm como objeto a administração e execução de planos de benefícios de natureza previdenciária, sendo vedada a prestação de quaisquer serviços que não estejam no âmbito de seu objeto $^{11} "$

É bem verdade, conforme explica o professor Romita, que os serviços assistenciais à saúde, que os Fundos de Pensão que já prestavam serviços assistenciais à saúde antes do advento da LC 109/2001 poderão continuar exercendo essa atividade, desde que estabelecido um custeio específico, "mediante contabilização e patrimônio mantido em separado em relação ao plano previdenciário ${ }^{12 "}$.

Dessa forma, a PREVI, por exemplo, não se confunde com o Banco do Brasil e nem tampouco a PETROS com a Petrobrás. Os Fundos de Pensão são entidades autônomas e os seus administradores não devem ter interesses estranhos ao objetivo da mesma, que é conseguir executar os planos de benefícios planejados a curto e longo prazo.

\subsubsection{Destinação dos resultados nos Fundos de Pensão}

Pelo fato de ser uma sociedade sem fins lucrativos, resultados superavitários são destinados à constituição de reserva de contingência, feita para garantir a execução dos benefícios no caso de uma eventual perda. Esta reserva possui um limite de $25 \%$ das reservas matemáticas.

Após constituída a reserva de contingência, os valores que a excederem serão utilizados para constituição da reserva especial para

\footnotetext{
${ }^{10}$ ROMITA, Arion Sayão. Estrutura da relação de previdência privada: entidades fechadas. Síntese Trabalhista, Porto Alegre, v 13, n 154, p 5-9, mar. 2002.

${ }^{11}$ Art. 32 e seu parágrafo único, da LC 109/2001.

${ }^{12}$ ROMITA, Arion Sayão, op. cit.
} 
revisão do plano de benefícios, a não utilização dessa reserva no prazo de três exercícios consecutivos determinará, obrigatoriamente, a revisão do plano de benefícios previdenciário, nos termos do art. 20, da LC 109/2001.

\subsubsection{Legislação aplicável}

Os Fundos de Pensão patrocinados ou instituídos por particulares são regidos unicamente pela LC 109/2001, que dá algumas diretrizes sobre o seu funcionamento.

Já no caso de a entidade ter, predominantemente, planos de benefícios patrocinados por empresas públicas e de economia mista ou outro órgão da Administração Pública, direta ou indireta, também lhe será aplicável a LC 108/2001.

\subsubsection{Os Fundos de Pensão e seus planos de benefícios}

A LC 109/2001 faz clara distinção entre o Fundo de Pensão e os seus planos de benefícios. O Fundo de Pensão é constituído como pessoa jurídica, criada com a finalidade de administrar e operar planos de benefícios de caráter previdenciário. Os planos de benefícios, por vez, são "a universalidade de direitos e obrigações a qual se vinculam os participantes e assistidos, os patrocinadores e instituidores ${ }^{13}$ ".

Um Fundo de Pensão pode albergar planos de benefícios de diferentes patrocinadores, sendo garantida a independência patrimonial entre esses planos, nos termos do art. 34, I, alínea "b”, da LC 109/2001.

A Resolução do Conselho de Gestão da Previdência Complementar ("CGPC") no 14/2004, um dos órgãos que regulam a atividade de previdência complementar, é expressa ao estabelecer que "os recursos de um plano de benefícios não respondem por obrigações de outro plano de

\footnotetext{
${ }^{13}$ REIS, Adacir. Curso Básico de Previdência Complementar. Editora Revista dos Tribunais: 2012, São Paulo. P. 25.
} 
benefícios operado pela mesmo Fundo de Pensão", evidenciando não só a independência entre planos de diferentes patrocinadores, mas também a independência entre planos do mesmo patrocinador.

Cada plano de benefícios tem um número de inscrição no Cadastro Nacional de Planos de Benefícios - CNPB, o que lhes confere identidade própria. Um plano de benefícios pode, dessa maneira, ser transferido, por exemplo, de um Fundo de Pensão para outro, mediante celebração de novo convênio de adesão e autorização da Superintendência Nacional de Previdência Complementar ("Previc"), mantendo o mesmo número no CNPB.

\subsubsection{Fiscalização da PREVIC}

Os Fundos de Pensão são obrigados a enviar à PREVIC os seguintes demonstrativos para que a Autarquia faça o monitoramento dos dados atuariais e dos investimentos realizados no âmbito de cada plano de benefícios: (i) Balancete Contábil, mensalmente; (ii) Demonstrativo de Investimentos, mensalmente; (iii) Demonstrativo Atuarial - DA, anualmente; e (iv) Demonstrações Contábeis - Balanço Patrimonial, anualmente.

\subsubsection{A estrutura organizacional dos Fundos de Pensão}

A administração dos Fundos de Pensão é composta por três órgãos. São eles: o Conselho Deliberativo, a Diretoria e o Conselho Fiscal.

O Conselho Deliberativo é a máxima instância nas deliberações dos fundos de pensão. A LC 109/2001 não atribui ao Conselho Deliberativo nenhuma competência específica, porém, segundo Adacir Reis ${ }^{14}$, os estatutos dos Fundos de Pensão frequentemente conferem ao órgão

\footnotetext{
${ }^{14}$ REIS, Adacir. Curso Básico de Previdência Complementar. Editora Revista dos Tribunais: 2012, São Paulo. P. 39.
} 
competência para: formular a política geral de investimentos; alterar estatutos e regulamentos, com posterior autorização da PREVIC; realizar operações de maior expressividade; aprovar a entrada ou retirada de patrocinadores e instituidores; e apreciar recursos interpostos contra a Diretoria Executiva.

Se o Fundo de Pensão é patrocinado, predominantemente, por entidades privadas, pelo menos um terço das cadeiras do Conselho Deliberativo deve ser preenchido por representantes dos participantes e assistidos, não tendo número máximo definido por lei.

Por outro lado, se o Fundo de Pensão é patrocinada, predominantemente, por empresas públicas e de economia mista ou órgão da Administração Pública, direta ou indireta, o número máximo de membros do Conselho Deliberativo é seis, conforme definido pela LC 108/2001, sendo metade deles eleitos pelos participantes e assistidos, por meio de eleição direta, e os outros três, dentre os quais o Presidente do Conselho, a quem caberá o voto de qualidade, pelos patrocinadores.

A Diretoria Executiva é responsável pela administração do fundo de pensão, a ela cabe o detalhamento e a execução das políticas gerais, formuladas pelo Conselho Deliberativo.

Segundo Adacir Reis, tal órgão é geralmente composto por um presidente ou diretor-superintendente, um diretor de investimentos, um diretor de benefícios ou de seguridade e um diretor de administração, porém essa composição dependerá do porte, volume de ativos administrados e complexidade dos planos de benefícios do Fundo de Pensão. Deverá ser designado, dentre os membros da Diretoria Executiva, um responsável pelas aplicações realizadas com os recursos do fundo de pensão ${ }^{15}$ e um

\footnotetext{
${ }^{15}$ Por força do art. 35, §5º da LC 109/2001 e Res. CMN 3.792.
} 
responsável pelo plano de benefícios ${ }^{16}$, sem prejuízo da responsabilidade dos demais.

Quando o Fundo de Pensão administrar, predominantemente, recursos entidades públicas, sua Diretoria Executiva deverá obedecer ao limite de até seis membros, além disso, é vedado a seus membros: (i) exercer simultaneamente alguma atividade na entidade patrocinadora; (ii) integrar concomitantemente o Conselho Deliberativo ou Fiscal da entidade e, mesmo depois do término do seu mandato na Diretoria-Executiva, enquanto não tiver suas contas aprovadas; e (iii) prestar serviços a instituições integrantes do sistema financeiro ao longo do exercício do mandato ${ }^{17}$.

Por último, o Conselho Fiscal é obrigatório nos Fundos de Pensão ${ }^{18}$, esse órgão é responsável pela fiscalização das contas do fundo de pensão e de seus planos de benefícios. No caso de regido somente pela LC 109/2001, um terço de seus membros deverão ser representantes de seus participantes ou assistidos, já no caso de ser regida também pela LC 108/2001, terá no máximo quatro membros, sendo os mesmos divididos paritariamente entre representantes dos patrocinadores e participantes e assistidos, cabendo aos últimos a indicação do Conselheiro Presidente, detentor do voto de qualidade.

Os Fundos de Pensão funcionam por meio do regime de capitalização e aplicação de seus investimentos: elas precisam reunir recursos para, mais tarde, pagar os benefícios de seus participantes, porém esses recursos não podem ficar reservados de forma indolente, é necessário que seus administradores lhe deem destino para que, aplicados, eles não sofram desvalorização.

\footnotetext{
${ }^{16}$ Res. CGPC $18 / 2006$.

${ }^{17}$ Art. 21 da LC 108/2001.

${ }^{18}$ Art. 35, caput, da LC 109/2001 e art. 14 da LC 108/2001.
} 
Os Fundos de Pensão devem observar, na gestão dos ativos dos planos de benefícios, a chamada meta atuarial. Na definição de Adacir Reis, meta atuarial é a "estimativa de desempenhos que os investimentos feitos por esse plano de previdência devem alcançar" ${ }^{\prime 19}$, dessa maneira, se a meta atuarial é o INPC acrescido de 7\%, os investimentos deverão alcançar, pelo menos, esse retorno.

O Estado regulador não confia totalmente na diligência dos administradores dos Fundos de Pensão, por isso, como se verá adiante, impõe limites máximos para aplicação de recursos dos planos de benefícios, de forma a diversificar os investimentos e diminuir os riscos dos mesmos.

\subsection{Delimitação do tema}

Apesar da enorme importância do estudo dos Fundos de Pensão e do enorme interesse que o tema desperta, o presente estudo tem o escopo de analisar apenas a responsabilidade de seus administradores, mas sem deixar a análise de algumas características essencial à administração e ao funcionamento de um Fundo de Pensão.

Apesar de o trabalho não pretender esgotar o assunto do regime jurídico dos Fundos de Pensão, será necessário, por vezes, explicar com minucia alguns aspectos de tais entidades para melhor compreensão do leitor.

Reitera-se que a produção doutrinária sobre o tema é baixa, conforme já alertado pelo professor Gustavo Saad, também pode haver dificuldades em encontrar casos concretos que abordem frontalmente alguns aspectos da responsabilidade dos administradores de fundos de pensão.

\footnotetext{
${ }^{19}$ REIS, Adacir. Curso Básico de Previdência Complementar. Editora Revista dos Tribunais: 2012, São Paulo. P. 83.
} 


\section{CAPÍTULO 2 - PLANOS DE BENEFÍ́CIOS ADMINISTRADOS POR ENTIDADES FECHADAS DE PREVIDÊNCIA COMPLEMENTAR}

\section{1.. Do objetivo dos Fundos de Pensão e seu vínculo com os participantes}

Entidades Fechadas de Previdência Complementar são criadas com o objetivo principal de instituir e executar planos de benefícios, nos termos da LC 109/2001, todavia o referido diploma legal não traz um conceito de planos de benefícios de forma expressa.

Arthur Bragança de Vasconcellos Weintraub ${ }^{20}$ entende que o vínculo entre Fundo de Pensão e participantes trata-se de relação de consumo, pois o participante é consumidor final se um serviço previsto no art. $3^{\circ}, \S 2^{\circ}$, do Código de Defesa do Consumidor.

A Súmula 563 do STJ confirma esse entendimento, quando declara que: "O Código de Defesa do Consumidor é aplicável às entidades abertas de previdência complementar, não incidindo nos contratos previdenciários celebrados com entidades fechadas", os contratos celebrados com os Fundos de Pensão são os convênios de adesão, que serão explicados à frente.

Weintraub atenta para a profunda interferência do Estados nesse setor, chegando a nomear a natureza do regime de previdência complementar como "Civil-Institucional".

O Estado, porém, permeando o caráter institucional da Previdência, mantém um caráter extremamente regulador, cerceando (com uma legislação extremamente minuciosa e burocratizante) de certa forma a supracitada liberdade contratual, em desprezo à contratualidade.

\footnotetext{
${ }^{20}$ WEINTRAUB, Arthur Bragança Vasconcellos. Responsabilidade dos Administradores de Fundos de Pensão. 1. ed. São Paulo: Juarez de Oliveira, 2004. P. 16.
} 


\subsection{Relação entre Fundos de Pensão e planos de benefícios}

\subsubsection{Fundo de Pensão como aclimatação do trust}

Carlos Eduardo Gabas ${ }^{21}$ afirma que a estrutura organizacional da previdência complementar, nos diversos ordenamentos jurídicos, pode ser agrupada em quatro diferentes classificações: (i) trust, no qual os administradores detém a propriedades dos recursos que administram; (ii) corporação, caso em que os participantes são donos legais dos fundos por meio da detenção das ações da sociedade que o administra; (iii) fundação, que, de forma similar ao trust, consiste em um conjunto de bens administrado pelos membros do conselho deliberativo; e (iv) arranjo contratual, referente a um montante de ativos destacados do patrimônio, sem caráter legal, e administrado por outra entidade.

Forçoso dizer que os Fundos de Pensão são autônomos, não podendo ser controladas pelo patrocinador, como será visto posteriormente, o que torna inaplicável ao Direito Brasileiro a segunda classificação. Também não parece o arranjo contratual ser a classificação mais adequada, uma vez que por meio desse negócio jurídico os recursos assumem natureza jurídica própria.

A estrutura organizacional da previdência complementar brasileira classifica-se, portanto, como fundações, que é uma forma de adaptação do contrato de trust.

Félix Ruiz Alonso ${ }^{22}$ explica que, nos Estados Unidos, são duas as formas jurídicas sob as quais os negócios de investimento são realizados: a

\footnotetext{
${ }^{21}$ GABAS, Carlos Eduardo. Aspectos Gerais da Gestão dos Fundos de Pensão. Disponível em: <http://www.previc.gov.br/central-deconteudos/publicacoes/artigos/2008/aspectos-gerais-da-gestao-dos-fundos-depensao.pdf/@@download/file/Aspectos\%20Gerais\%20da\%20Gest\%C3\%A3o\%20dos\%2 0Fundos\%20de\%20Pens\%C3\%A3o.pdf> Acesso em 24.05.2016.

${ }^{22}$ ALONSO, Félix Ruiz. Os fundos de investimento. Condomínios mobiliários. Revista da Faculdade de Direito, Universidade de São Paulo, [S.1.], v. 66, p. 223-271, jan. 1971.
} 
forma societária e a forma contratual ou trust, definindo o último como um negócio jurídico que reparte a propriedade entre o administrador e o proprietário originário com vistas a proporcionar benefícios para um terceiro (ou para o próprio proprietário originário).

(...) o trust é peculiar do âmbito jurídico anglo-americano. Como é sabido consiste essencialmente na bipartição da propriedade entre duas pessoas, entre o investidor, proprietário originário ou "settlor" e o administrador ou "trustee". Esta [é] a peculiaridade anglo-americana, o administrador do investimento é também proprietário - embora com uma propriedade limitada segundo os lineamentos do contrato "trust agreement" ou "trust identure" - assinado entre $o$ instituidor e o administrador. Finalmente aparece um terceiro que é o beneficiário do investimento, chamado "cestui qui trust" e que no caso é, de ordinário, o mesmo investidor.

Para o Direito Americano, os Fundos de Pensão estão inseridos no conceito de trust, o mesmo conceito utilizado para definir os Fundos de Investimento, em geral. Nesse mesmo sentido, expõe-se o entendimento de Alastair Hudson ${ }^{23}$ :

The growing economic importance of pension funds has profound ramifications for the social significance of trusts law principles. Pension funds are trusts. Consequently, the rights of pensioners, of pension fund managers and of employers creating occupational pension funds for their employees are governed by general principles of trusts law, the precise provisions of pension fund deeds and the provisions of those statutes which have been enacted specifically in relation to pension fund trusts.

O trust, segundo o professor Diogo Leite de Campos, tem grande dificuldade em ser aclimatado pelos países de tradição romano-germânica, pois o rol de direitos reais, cuja previsão se encontra no art. 1.225 do Código Civil, é, para a doutrina, taxativo, não comportando nova espécie de ônus real mediante previsão em contrato.

(...) qualquer acordo entre as partes destinado à constituição de um trust envolveria, forçosamente, a constituição de um ônus real sobre a res em trust estendendo, deste modo, o conceito de propriedade às pretensões, presentes e futuras dos beneficiários, esse acordo não pode produzir efeitos reais. Além do mais, a criação de um direito real limitado novo relativamente àqueles já

ISSN 2318-8235. Disponível em: <http://www.revistas.usp.br/rfdusp/article/view/66628>. Acesso em 25.03.2016.

${ }^{23}$ HUDSON, Alastair. Ocupational Pension Funds. Disponível em: <http://www.alastairhudson.com/trustslaw/pensions.pdf >. Em 04.05.2016. 
previstos pelo legislador viria a afectar os adquirentes do direito de propriedade, ou de outro direito real, com uma concreta limitação das faculdades que constituem o conteúdo de tais direitos.

Uma possibilidade de adaptação do trust ao Direito Brasileiro pode ser através de fundações: um conjunto de bens vai formar nova pessoa jurídica, destacada do seu donatário, para cumprir determinados fins, de assistência, por exemplo.

A fundação se diferencia do trust porque nessa o administrador não adquire a propriedade dos bens, estes passam, tão somente, a constituir pessoa jurídica diversa do doador para fins de conceder benefícios a terceiros.

A LC 109/2001 permite aos Fundos de Pensão assumir tanto a forma de fundações, como de sociedades civis, o que permite uma adaptação do instituto americano, que influenciou o nosso modelo de previdência complementar, ao Direito Brasileiro. A esse respeito, diz Raquel do Amaral de Oliveira Santos ${ }^{24}$ :

Em certos casos, fundações e trusts podem ser utilizados com o mesmo propósito, qual seja, a consecução de uma finalidade social. Vimos que existem os chamados charitable trusts, os quais também consistem na colocação de um patrimônio com vistas a um fim caritativo.

\subsubsection{Planos de benefícios como condomínios}

Os planos de benefícios apesar de, em seu conjunto, poderem formar um fundo de pensão constituído sob a forma de fundação, não se confundem com a pessoa jurídica.

Quando constituídos sob a forma de sociedade civil, os Fundos de Pensão não têm a livre disponibilidade dos bens que compõem o seu

\footnotetext{
${ }^{24}$ SANTOS, Raquel do Amaral de Oliveira. Trust: Das origens à aceitação pelos países de direito romano-germânico. Disponível em: <http://www.dominiopublico.gov.br/download/teste/arqs/cp086499.pdf>. Acesso em: 23.05.2016.
} 
patrimônio: esses bens estão afetos às obrigações do plano de benefícios a que integram.

O que acontece é que, ao receber a propriedade dos recursos, os Fundos de Pensão obrigam-se a constituir um patrimônio em separado administrado por regras específicas para cumprimento de determinadas obrigações. A esse patrimônio dá-se o nome de plano de benefícios.

Por se tratar de um conjunto de bens administrados de forma independente com vistas a um retorno financeiro, os planos de benefícios apresentam características semelhantes aos dos fundos de investimento, não se descaracterizando como tal pelo fato de serem administrados pelo próprio investidor ou de haver apenas um cotista, situações permitidas também na regulamentação dos fundos de investimento ${ }^{25}$.

Em decorrência da forte semelhança entre os planos de benefícios e os fundos de investimentos, a natureza jurídica dos dois deverá ser a mesma para que a coerência interna do sistema seja mantida. De acordo com Iara Menezes Lima ${ }^{26}$ :

(...) qualquer que seja essa lei e por menor que seja o seu texto, jamais pode ser desprezada a sua coerência interna. Todas as normas constantes de qualquer lei devem compatibilizar-se internamente, formando um todo harmônico. (...)

${ }^{25}$ Art. 78. A administração do fundo compreende o conjunto de serviços relacionados direta ou indiretamente ao funcionamento e à manutenção do fundo, que podem ser prestados pelo próprio administrador ou por terceiros por ele contratados, por escrito, em nome do fundo. $\S 1^{\circ}$ Podem ser administradores de fundo de investimento as pessoas jurídicas autorizadas pela CVM para o exercício profissional de administração de carteiras de valores mobiliários, nos termos do art. 23 da Lei ${ }^{\circ}$ 6.385, de 7 de dezembro de 1976 e instrução específica.

Art. 130. Considera-se "Exclusivo" o fundo para investidores profissionais constituído para receber aplicações exclusivamente de um único cotista.

$\S 1^{\circ} \mathrm{Na}$ emissão e no resgate de cotas do fundo exclusivo pode ser utilizado o valor de cota apurado de acordo com o disposto no $\S 1^{\circ}$ do art. 16, segundo dispuser o regulamento.

$\S 2^{\circ} \mathrm{O}$ disposto no $\S 1^{\circ}$ não se aplica caso o fundo exclusivo tenha como cotista outro fundo de investimento que não esteja autorizado a utilizar a faculdade prevista no $\S 1^{\circ}$ do art. 16.

${ }^{26}$ LIMA, Iara Menezes. Métodos Clássicos de Interpretação no Direito Constitucional. Disponível em <http://www.pos.direito.ufmg.br/rbepdocs/092065098.pdf>. Acesso em 24.05.2016. 
Não obstante a diversidade de teorias criadas para explicar a natureza jurídica dos fundos de investimento - a copropriedade, comunhão de bens não condominial, propriedade fiduciária propriedade em mão comum e organização associativa - a corrente majoritária é a que classifica o fundo de investimento como um condomínio, em linha com a regulamentação promovida pela CVM na Instrução $n^{0} 555^{27}$.

Posição semelhante encontra-se explicitada no Processo CVM nr. 2001/185728, que trata o fundo de investimento como uma comunhão de recursos:

7. $O$ fundo de investimento consiste na comunhão de recursos entregues a um administrador para a aplicação em carteira de títulos e valores mobiliários. A constituição do fundo é deliberada por seu administrador, a quem cabe também aprovatr o regulamento. Seu funcionamento, entretanto, depende de prévia autorização da CVM e a participação do investidor se dá através de quotas que representam frações ideais de patrimônio do fundo.

\subsection{3. $O$ surgimento dos fundos de investimento}

Félix Ruiz Alonso ${ }^{29}$ revela que os fundos de investimento tiveram início legalmente com a Portaria $\mathrm{n}^{\mathbf{0}} 309$, no ano de 1959 , que permitiu às Companhias de Crédito e Financiamento "a constituição de fundos em condomínio". Isto é, o conceito condominial estava presente no embrião do instituto.

\footnotetext{
${ }^{27}$ Art. $3^{\circ} \mathrm{O}$ fundo de investimento é uma comunhão de recursos, constituído sob a forma de condomínio, destinado à aplicação em ativos financeiros.

28 MARTINS, Danilo Ribeiro Miranda. O conflito de interesses no Sistema Previdenciário Complementar. Disponível em: <http://bdjur.stj.jus.br/jspui/bitstream/2011/46270/conflito_\%20interesses_sistema_marti ns.pdf $>$. Acesso em: 04 de abril de 2016.

${ }^{29} \mathrm{ALONSO}$, Félix Ruiz. Os fundos de investimento. Condomínios mobiliários. Revista da Faculdade de Direito, Universidade de São Paulo, [S.1.], v. 66, p. 223-271, jan. 1971. ISSN 2318-8235. Disponível em: <http://www.revistas.usp.br/rfdusp/article/view/66628>. Acesso em 25.03.2016.
} 


\subsubsection{A figura do administrador nos condomínios}

Nota-se que em qualquer condomínio pode haver a figura do administrador, que assumirá o papel de procurador comum de todos, respondendo pela gestão do condomínio, conforme ensinamento de Orlando Gomes $^{30}$ :

Deliberado que a coisa comum seja administrada, os condôminos escolherão o administrador, que terá a condição de procurador comum. Não é necessário que a escolha recaia num dos condôminos. (...) Ao administrador incumbe partilhar os frutos da coisa comum na proporção dos quinhões. Evidentemente, responde pela gestão.

De acordo com Ricardo Freitas ${ }^{31}$, a única pessoa autorizada a contratar dívidas com o patrimônio do fundo é o administrador:

Em nenhuma das espécies de fundos reguladas pelo direito brasileiro existe a possibilidade de um dos condôminos contrair dívidas em nome da comunhão. A única pessoa autorizada a praticar tal ato seria o administrador do fundo, ou, por delegação de poderes deste, o gestor. Estes, ainda assim, estão sujeitos à forte restrição quanto à celebração de determinados atos jurídicos, em nome do fundo, que possam implicar contratação de dividas.

Dissonante à essa ideia, apresentada no tópico anterior, de que seriam os fundos de investimento condomínios, tem-se o entendimento de Arnoldo Wald ${ }^{32}$, para quem o fundo de investimento "é uma fórmula fiduciária pela qual os investimentos podem ser realizados em nome do fiduciário e interesse do fiduciante, assemelhando-se ao 'trust'(...)". Todavia, para o doutrinador, tal distinção não configura o elemento principal da discussão acerca da administração dos fundos de investimento:

Quer se cogite em condomínio especialíssimo ou sui generis, de uma sociedade sem personalidade jurídica, na terminologia do Código de Processo Civil, ou de uma forma de trust já adaptado e consagrado pelo Direito Brasileiro, a designação e a semântica são secundários, pois o importante é a capacidade

\footnotetext{
${ }^{30}$ GOMES, Orlando. Direitos reais. Rio de Janeiro: Forense, 2002. P. 219-220.

${ }^{31}$ FREITAS, Ricardo de Santos. Natureza jurídica dos fundos de investimento. São Paulo: Quartier Latin, 2006. P. 168.

${ }^{32}$ DOTTA, Ricardo Montenegro. A responsabilidade dos administradores de fundos de investimentos no novo código civil: uma abordagem da indústria dos fundos de investimento, voltada para a natureza da responsabilidade de seus administradores, sob a ótica dos novos princípios orientadores do direito privado e da regulamentação do setor. São Paulo: Textonovo, 2005. P. 99.
} 
subjetiva e adjetiva do Fundo para adquirir e transmitir direitos, atuar em Juízo e praticar todos os atos da vida comercial, embora só possa exercer sua atividade por intermédio de seu gestor.

\subsubsection{O problema da representatividade dos fundos de pensão}

Os investidores participam ativamente da administração do fundo por meio da assembleia geral. Essa é uma forma do investidor - que é quem está efetivamente correndo os riscos do negócio - exprimir a sua satisfação com relação àquela administração.

$\mathrm{O}$ art. 66 da Instrução CVM n ${ }^{\circ}$ 555, à semelhança do art. 47 da revogada Instrução CVM no 409, traz um rol de assuntos cuja deliberação é de competência privativa da assembleia geral de cotistas ${ }^{33}$ - porém, deve-se atentar para o fato de que esse rol não exaure as matérias de competência privativa da assembleia geral de cotistas.

Os fundos de pensão, por outro lado, não possuem a previsão de uma assembleia geral para participantes, o que restringe o envolvimento e a supervisão dos participantes na gestão e administração dos seus recursos.

Caso a administração não esteja sendo satisfativa, o único que pode denunciar o contrato de previdência privada é o patrocinador. Respondendo, inclusive, pela não denúncia em casos de má administração.

\footnotetext{
${ }^{33}$ Art. 66. Compete privativamente à assembleia geral de cotistas deliberar sobre: I - as demonstrações contábeis apresentadas pelo administrador;

II - a substituição do administrador, gestor ou custodiante do fundo;

III - a fusão, a incorporação, a cisão, a transformação ou a liquidação do fundo;

IV - o aumento da taxa de administração, da taxa de performance ou das taxas máximas de custódia;

$\mathrm{V}$ - a alteração da política de investimento do fundo;

VI - a emissão de novas cotas, no fundo fechado;

VII - a amortização e o resgate compulsório de cotas, caso não estejam previstos no regulamento; e

VIII - a alteração do regulamento, ressalvado o disposto no art. 47.
} 


\subsection{A independência com relação aos benefícios do INSS}

O nome "previdência complementar" advém da ideia de que os benefícios dessa previdência são complementares aos benefícios do INSS. Assim ocorre porque alguns planos de benefícios, anteriores à legislação vigente, vinculavam a concessão de seus benefícios à concessão dos benefícios do INSS.

Essa ideia tornou-se desconjecturada com o advento da LC 109/2001, que em seu art. $68, \S 2^{\circ}$, que estabelece independência entre a concessão dos referidos benefícios. Embora seja importante observar que a LC 108/2001 traz algumas exceções a essa independência para os Fundos de Pensão patrocinados por entidades integrantes da Administração Pública.

\subsection{A identidade própria dos planos de benefícios}

$\mathrm{O}$ art. 34, II, b, da LC 109/2001 reconhece expressamente a existência do Fundo de Pensão "mutipatrocinado", ou seja, a que administra planos de investimento de diferentes patrocinadores ou instituidores. Em tese, tais entidades são extremamente positivas aos investidores, pois reduzem os custos administrativos e geram ganhos de escala com os investimentos das reservas técnicas.

Porém, conforme já aludido, esses planos de benefícios serão independentes entre si, não podendo o Fundo de Pensão se valer dos recursos de um para arcar com despesas de outro.

A Res. 14/2004 do Conselho de Gestão de Previdência Complementar ("CGPC") estabelece que em decorrência da independência patrimonial aludida cada plano de benefício possui identidade própria 
quanto aos aspectos regulamentares, cadastrais, atuariais, contábeis e de investimentos.

A identidade própria dos planos de benefícios é conferida através de sua inscrição no Cadastro Nacional de Planos de Benefícios ("CNPB") e, embora os recursos dos planos de benefícios estejam sob o abrigo do Cadastro Nacional de Pessoas Jurídicas ("CNPJ") tal medida tem fins meramente administrativos, estando os bens de um mesmo plano de benefício afetado às obrigações relativas ao CNPB.

É admitida a transferência de um plano de benefícios de um Fundo de Pensão para outro, conforme a redação do art. 33, IV, da LC 109/2001, desde que a PREVIC autorize e seja celebrado um novo convênio de adesão. Nesse caso, embora se mude o Fundo de Pensão, o plano de benefícios continuará a ter o mesmo CNPB e será regido pelo mesmo regulamento.

\subsection{Planos de benefícios e as diretrizes estabelecidas pelo CMN}

O $\S 1^{\circ}$ do art. $9^{\circ}$ da LC 109/2001 estabelece que a "aplicação dos recursos correspondentes às reservas, às provisões e aos fundos (de previdência complementar)" será realizada de acordo com as diretrizes estabelecidas pelo Conselho Monetário Nacional (“CMN").

Em razão da independência entre planos de benefícios, estabelecida no art. 34 da LC 109/2001, os limites estabelecidos pelo CMN - presentes na Resolução CMN no 3.792/2009 - devem ser analisados individualmente em cada plano, ou seja, o enquadramento aos limites da Resolução não deve ser analisados levando em consideração o conjunto de planos administrados pelo Fundo de Pensão, mas cada um dos planos que a mesma administra. 


\subsection{Fiscalização das aplicações dos recursos de planos de benefícios}

Os Fundos de Pensão devem encaminhar, para que seja possível realizar o monitoramento do plano atuarial e dos investimentos, os seguintes documentos à Previc: Balancete Contábil e Demonstrativo de investimentos, mensalmente, e Demonstrativo Atuarial e Demonstrações Contábeis, anualmente.

\subsection{Modalidades de planos de benefícios}

O parágrafo único do art. $7^{\circ}$ da LC 109/2001 dispõe que o "órgão regulador e fiscalizador normatizará planos de benefícios nas modalidades de benefício definido, contribuição definida e contribuição variável, bem como outras formas de planos de benefícios".

Para efeito de classificação do plano de benefício em uma das três modalidades descritas, a Resolução CGPC n ${ }^{\circ}$ 16/2005 estabelece que o parâmetro a ser utilizado é o do benefício principal, ou seja, desconsidera nessa análise o tratamento dado aos benefícios de risco, que são, por exemplo, os benefícios concedidos em decorrência de invalidez ou morte.

Cabe aqui explanar uma breve síntese sobre cada uma das três modalidades.

\subsubsection{Plano de Benefício Definido}

Na modalidade de Benefício Definido, a contribuição realizada pelos participantes é indefinida, isso porque se o benefício é definido, mas o retorno das aplicações é variável, é necessário que as contribuições se adéquem à necessidade atuarial. Isto é, o equilíbrio entre os benefícios pagos e as contribuições recebidas de dará mediante adequação dessas últimas às necessidades daqueles primeiros. 
As regras para o custeio, bem como as regras para a concessão de benefícios desses planos deverão estar expressas no regulamento, porém, caso verificado o resultado positivo dos investimentos realizados pelo fundo de pensão, a contribuição será reduzida, suprimida e, até mesmo, devolvida; por outro lado, caso se verifique prejuízo, será necessária a majoração da contribuição.

Nesse tipo de plano, o custeio é determinado em razão das hipóteses atuariais adotadas, como o crescimento real dos salários, rotatividade, taxa de juros, etc. É importante a adoção da hipótese de longevidade, uma vez que, uma vez concedido, o benefício será concedido vitaliciamente.

Como nesse tipo de plano os cálculos atuariais são feitos levando em consideração o conjunto de participantes ou assistidos, uma de suas características básicas é a solidariedade.

Os fundos de investimentos americanos nasceram sob a responsabilidade integral das empresas patrocinadoras pelo custeio das contribuições, este é o motivo da origem da expressão "patrocínio", no sentido de financiamento do plano.

A previdência complementar no Brasil foi fortemente influenciada pelo modelo americano, taí por que na sua primeira regulamentação, com a Lei Federal 6.435/1977 - revogada pela LC 109/2001, a maior parte dos planos de benefícios seguiam a modalidade benefício definido.

A partir da década de 90, em que as empresas resolveram reduzir o seu risco pelo custeio das contribuições, os planos de benefícios administrados por fundos de pensão americanos passaram a adotar novos modelos e o Brasil acompanhou essa tendência.

Hoje, apesar de ainda haverem importantes planos de benefício definido operados por Fundos de Pensão, a maioria deles encontra-se sob a 
regra do art. 16, § $3^{\circ}$, da LC 109/2001, que é o regime de extinção, no qual é vedado o acesso de novos participantes.

\subsubsection{Plano de Contribuição Definida}

A característica dessa modalidade é que suas contribuições são definidas, seus benefícios, porém, indefinidos.

$\mathrm{Na}$ verdade, a regra não é absoluta, geralmente é dado ao participante ou assistido, a possibilidade de aportar um valor variável, mas não por exigência dos cálculos atuariais, mas sim para aumentar o seu saldo mantido em conta.

Geralmente, nesse tipo de plano de benefícios, os regulamentos preveem uma contribuição mínima para os participantes e uma contribuição fixa ou máxima para os patrocinadores.

Também o benefício nesse tipo de plano não é vitalício, sendo pago por tempo certo com base em um percentual aplicado ao saldo em conta. $\mathrm{O}$ benefício principal será sempre o recebimento paulatino de parcelas do saldo mantido na conta do participante ou assistido, já no caso dos benefícios de risco, estes podem ter características dos planos de benefício definido.

\subsubsection{Plano de Contribuição Variável}

O Plano de Contribuição Variável nada mais é que um modelo híbrido das duas modalidades já tratadas. Nele, tanto a contribuição quanto o benefício são variáveis e essa variação se dá tanto pela liberalidade do participante ou assistido, que deseja aumentar o seu saldo em conta, como também pelas imposições do cálculo atuarial.

Nessa modalidade, geralmente o benefício principal é calculado com base no saldo em conta, mas uma vez concedido, torna-se vitalício, à diferença do que ocorre no Plano de Contribuição definida, onde o 
benefício principal também é calculado com base no saldo, mas é pago durante um período definido.

Outra característica que esse tipo de plano pode adotar é a conciliação de um benefício mínimo definido, calculado atuarialmente, e um benefício resultando do saldo de conta. 


\section{CAPÍTULO 3 - TRIBUTAÇÃO dOS PLANOS DE PREVIDÊNCIA COMPLEMENTAR}

\subsection{Com relação os Fundos de Pensão}

\subsubsection{Da ocorrência ou não de fato gerador do Imposto de Renda}

\subsubsection{Incidência quanto às contribuições: inocorrência de acréscimo patrimonial}

Os planos de benefícios caracterizam-se como poupança de longo prazo, sendo, pela sistemática do Direito Tributário, a tributação na fase de acumulação desses investimentos não é abrangida pelo imposto do art. 43 do Código Tributário Nacional (“CTN”) 34 .

Além disso, é fundamental para a incidência do Imposto de Renda, a ocorrência de acréscimo patrimonial. Nesse sentido, o Ministro Carlos Velloso reproduziu seu voto no julgamento do Recurso Extraordinário ${ }^{\circ}$ 201465-6-MG, em 02.05.2002:

No voto que proferi por ocasião do citado julgamento, asseverei que não seria "possivel a afirmativa no sentido de que possa existir renda ou provento sem que haja acréscimo patrimonial, acréscimo patrimonial que ocorre mediante o ingresso ou o auferimento de algo, a título oneroso(...)".

Ricardo Mariz de Oliveira ${ }^{35}$ chama atenção para o fato que patrimônio é o conjunto, tanto de bens e direitos, quanto de obrigações, e

\footnotetext{
${ }^{34}$ Art. 43. O imposto, de competência da União, sobre a renda e proventos de qualquer natureza tem como fato gerador a aquisição da disponibilidade econômica ou jurídica:I de renda, assim entendido o produto do capital, do trabalho ou da combinação de ambos; II - de proventos de qualquer natureza, assim entendidos os acréscimos patrimoniais não compreendidos no inciso anterior.

$\S 1^{\circ} \mathrm{A}$ incidência do imposto independe da denominação da receita ou do rendimento, da localização, condição jurídica ou nacionalidade da fonte, da origem e da forma de percepção.

$\S 2$ o Na hipótese de receita ou de rendimentos oriundos do exterior, a lei estabelecerá as condições e o momento em que se dará sua disponibilidade, para fins de incidência do imposto referido neste artigo.

${ }^{35}$ OLIVEIRA, Ricardo Mariz. Fundamentos do Imposto de Renda. São Paulo: Quartier Latin, 2008. P. 46.
} 
esse último costuma não ser levado em consideração na análise do acréscimo patrimonial. Diz ele:

\begin{abstract}
Assim é porque geralmente as pessoas vêem apenas o lado positivo do patrimônio, representado por aqueles bens que o seu titular ostenta à vista de todos. A partir disso, considera-se rico - portanto, titular de patrimônio vultuoso - aquele que anda em automóveis de luxo, ou voa de helicóptero, ou navega em lancha de porte, ou reside numa mansão, ou viaja em primeira classe, ou por apenas uma interminável série de situações que apenas podem ser índices presumíveis de riqueza, mas que não passam de alguns objetos do patrimônio, $e$ sequer têm consistência absoluta para garantir a incidência do imposto de renda.
\end{abstract}

A ideia que Mariz de Oliveira pretende demonstrar é que o aumento no ativo dentro de um balanço patrimonial não configura acréscimo patrimonial quando acompanhada por um aumento no passivo, seja ele circulante ou de longo prazo. Para que esse acréscimo ocorra há necessidade que a contrapartida ao aumento no ativo se dê no patrimônio líquido.

Para ilustrar, tem-se o seguinte exemplo: um indivíduo comprou um automóvel de modelo novo no valor de $\mathrm{R} \$ 60.000,00$; se para comprá-lo foi necessário fazer um empréstimo no valor de $\mathrm{R} \$ 100.000,00$ - que será pago no decorrer de 5 anos, a operação gerou um decréscimo patrimonial, embora o comprador aparente ter tido um acréscimo.

Por isso, é altamente questionável a ocorrência do fato gerador do Imposto de Renda aos Fundos de Pensão, pois, caso se entenda que ela adquire a disponibilidade econômica ou jurídica dos bens que administra, deve-se levar em consideração que ela assume a obrigação de realizar o pagamento de todos os beneficiários daquele plano.

\title{
3.1.1.2. Incidência quanto aos resultados positivos das aplicações de recursos dos planos de benefícios
}

Quanto aos resultados positivos obtidos pelos Fundos de Pensão, eles não serão distribuídos para seus sócios, mas aplicados no pagamento de planos de benefícios, então, usando o mesmo raciocínio do capítulo 
anterior, quanto maior o resultado, maior será a obrigação de pagar os beneficiários dos planos, inexistido acréscimo patrimonial.

Merece, portanto, críticas o posicionamento defendido pelo Tribunal Regional Federal da $1^{\mathrm{a}}$ Região no AMS 42761 MG 004276193.2001.4.01.3800, em que se decidiu a ocorrência de lucro independe da finalidade que a entidade exerce, em havendo resultado positivo, incidirão Imposto de Renda e Contribuição Social Sobre o Lucro Líquido sobre o montante ${ }^{36}$.

${ }^{36}$ PROCESSO CIVIL E TRIBUTÁRIO. MANDADO DE SEGURANÇA. ABRAPP ASSOCIAÇÃO BRASILEIRA DAS ENTIDADES FECHADAS DE PREVIDENNCIA COMPLEMENTAR. IR. CSSL. ENTIDADES FECHADAS DE PREVIDÊNCIA PRIVADA. INCIDÊNCIA. DESEQUIPARAÇÃO LEGAL EM RELAÇÃO ÀS ENTIDADES ABERTAS. AUSÊNCIA DE VIOLAÇÃO AO PRINCÍPIO DA ISONOMIA. 1. "As entidades fechadas de previdência complementar não estão desobrigadas ao recolhimento da Contribuição Social Sobre o Lucro (CSSL) e do Imposto de Renda (IR). A CSSL é devida pelas entidades de previdência complementar fechadas (sem fins lucrativos) desde o advento da Lei $n^{o} 8.212 / 91$ (art. 23, c.c. 22, $\$ 1^{\circ}$ ). A isenção a esse recolhimento só poderia se dar, como de fato se deu, no ano de 2002, após o ajuizamento da lide, por força de lei. A tese de que não possui lucro não prospera. Havendo resultado positivo (econômicofinanceiro) em suas operações diversas (superávit), tal resultado é suficiente, à luz do artigo 195, caput, da Constituição Federal para justificar a incidência tributária à luz do postulado da solidariedade social de que se revestem as contribuições aí previstas. Não tem nenhuma importância para a determinação da efetiva existência do lucro ter a entidade finalidade lucrativa ou não, bastante sua ocorrência material (lucro), a exigência fiscal mostra-se legítima. Quanto ao imposto de renda, o mesmo raciocínio há de ser empregado: auferindo riqueza - signo presuntivo de riqueza qualquer - deve incidir a tributação prevista no artigo 43 do CTN. A Jurisprudência já orienta no sentido de que"o patrimônio das entidades fechadas de previdência privada compõe-se de valores provenientes das contribuições de seus participantes, de dotações da própria entidade e de aporte do patrocinador, enfim, mesmo que não possuam fins lucrativos, é cabivel a incidência do imposto de renda e da contribuição sobre o lucro, pois na sua atividade captam e administram os recursos destinados ao pagamento de benefícios de seus associados"(TRF4, AC 2002.71.00.005862-3). A desequiparação legal das entidades fechadas das abertas de previdência complementar, no tocante à forma de recolhimento do Imposto de Renda (art. $2^{o}$, $\$ 3^{o}$, da MP 2.222/2001), não ofende postulados constitucionais, em especial o da isonomia." (AMS 200161000316914, Relator (a) JUIZ WILSON ZAUHY, - 284036, DJF3 CJI DATA:29/04/2011, PÁGINA: 1079, JUDICIÁRIO EM DIA - TURMA C). Precedentes da $2^{a}, 3^{a}, 4^{a}$ e $5^{a}$ Regiões, envolvendo a mesma Impetrante. 2. Apelação da Impetrante a que se nega provimento. Apelo da União e remessa oficial a que se dá provimento.

APELAÇÃO EM MANDADO DE SEGURANÇA n ${ }^{\circ}$ 96056/PE(2001.83.00.023913-0), Relator: Desembargador Élio Siqueira. Segunda Turma do TRF-5. Disponível em: <http://www.abrapp.org.br/MandadoSegurancaColetiva/ACORDAO_MS_002391330200 14058300_Recife.pdf>. Acesso em 08.05.2016. 


\subsubsection{Da existência de aquisição de disponibilidade}

A aquisição da disponibilidade dos recursos administrados pelos Fundos de Pensão é outro ponto que merece atenção.

Hugo de Brito Machado $^{37}$ define aquisição da disponibilidade econômica como posse livre e desembaraçada da riqueza. Ou seja, é quando, além de haver a existência do direito, esse é realizado.

(...) a possibilidade de dispor, possibilidade de fato, material, direta, da riqueza. Possibilidade de direito e de fato, que se caracteriza pela posse livre e desembaraçada da riqueza. Configura-se pelo efetivo recebimento da renda ou dos proventos.

Na mesma lição, o autor classifica também a disponibilidade jurídica como o direito que credor tem, mas que ainda não foi realizado, o que ocorre, por exemplo, no recebimento de um cheque.

(...) configura-se, em princípio, pelo crédito da renda ou dos proventos. Enquanto a disponibilidade econômica corresponde ao rendimento realizado, a disponibilidade jurídica corresponde ao rendimento (ou provento) adquirido, isto $e ́$, ao qual o beneficiário tem título jurídico que lhe permite obter a respectiva realização em dinheiro (p. ex., o juro ou dividendo creditados).

Rubens Gomes de Souza ${ }^{38}$, em parecer emitido em 1970, alega que a disponibilidade econômica refere-se a rendimento ou provento realizado, enquanto a disponibilidade jurídica relaciona-se a provento ou rendimento já adquirido, porém não realizado.

O Tribunal Regional Federal da $5^{\mathbf{0}}$ Região, no julgamento do Processo $\mathrm{n}^{\mathrm{o}}$ 0012655-76.2010.4.05.0000, explica que simples posse de coisa móvel e fungível, de acordo com a sistemática civil, gera a obtenção

\footnotetext{
${ }^{37}$ MACHADO, Hugo de Brito. Comentários ao Código Tributário Nacional. $2^{\mathrm{a}}$ ed. Atlas, 2007. P. 448.

${ }^{38}$ MACHADO, Brandão. Estudos Sobre o Imposto de Renda (Em Memória de Henry Tilbery). Coordenação: Ives Gandra Martins. Editora Resenha Tributária Ltda.: São Paulo, Julho de 1994. P. 122.
} 
da propriedade ${ }^{39}$. Caracterizando a aquisição da disponibilidade econômica dos recursos pelos Fundos de Pensão.

Esse ponto foi sabiamente levantado pela autoridade julgadora, uma vez que, de acordo com o art. 109 do CTN, faz-se uso dos institutos de direito privado para o conteúdo e alcance das normas tributárias.

\subsubsection{Da isenção do Imposto de Renda para Fundos de Pensão e imunidade tributária de tais entidades}

A Lei 6.435/1977 estabelecia que, para efeitos de tributação, os Fundos de Pensão eram consideradas instituições de assistência social e, dessa maneira, gozavam de imunidade tributária. Essa regra veio a ser suprimida com o advento do Dec.-lei 2.065/1983, que foi editado pelo Governo Federal com a intenção de aumentar a arrecadação.

Muitas ações foram impetradas com o objetivo de proteger os investimentos dos recursos previdenciários, alegando que se estaria tratando de imunidade tributária prevista no art. 150, IV, c, da CRFB, mas sem sucesso. Somente em 2001 o STF, no RE 202.700, entendeu que os planos

39 TRIBUTÁRIO. PROCESSUAL CIVIL. PRETENSÃO DE NÃO INCIDÊNCIA DE IMPOSTO DE RENDA SOBRE VALORES PERCEBIDOS A TÍTULO DE COMPLEMENTAÇÃO DE APOSENTADORIA. IMPOSSIBILIDADE. AQUISIÇÃO (REAQUISIÇÃO, COMO SE QUEIRA) DA DISPONIBILIDADE ECONÔMICA. FATO GERADOR DO IR. TRIBUTAÇÃO DEVIDA.(...)

4. Os argumentos, todavia, improcedem: a posse de coisa móvel fungível (como o dinheiro) gera a obtenção da respectiva propriedade (pelo fundo de pensão), consoante comezinha lição de direito civil; vai daí que a Entidade Fechada de Previdência Complementar não detém o dinheiro dos empregados (como estes sugerem em seus arrazoados), senão que exerce a plena propriedade do capital que tem consigo; o que, então, teria o empregado mercê das contribuições, créditos e direitos exercíveis (se é que serão) a posteriori, os quais normalmente significam ganhos maiores que os numerários vertidos para o fundo (já que o benefício é definido sem termo certus quando), o que também quebra a lógica daquele sinalagma cartesiano -- igualitário -- defendido pelos autores; o patrimônio que entra não é igual (jurídica ou quantitativamente) àquele que sai do fundo de pensão;

(...)

STJ - REsp: 1306333 CE 2011/0183487-0, Relator: Ministro OG FERNANDES, Data de Julgamento: 07/08/2014, T2 - SEGUNDA TURMA, Data de Publicação: DJe $19 / 08 / 2014$ 
de previdência complementar mantidos integralmente pelos patrocinadores podiam ser enquadrados no conceito de entidade de assistência social. Como quase todas os planos recebem contribuições dos participantes, a decisão pouco beneficiou a previdência privada.

Com a edição da Lei 11.053/2004, os Fundos de Pensão passaram a não mais pagar IRPJ. Diz o art. $5^{\circ}$ do referido diploma:

Art. $5^{\circ}$ A partir de $1^{\circ}$ de janeiro de 2005, ficam dispensados a retenção na fonte e o pagamento em separado do imposto de renda sobre os rendimentos e ganhos auferidos nas aplicações de recursos das provisões, reservas técnicas e fundos de planos de benefícios de entidade de previdência complementar, sociedade seguradora e FAPI, bem como de seguro de vida com cláusula de cobertura por sobrevivência.

(...)

Apesar de restarem isentas do pagamento do IRPJ, é importante asseverar que a jurisprudência entende que, como regra, ocorre a aquisição da disponibilidade econômica ou jurídica dos recursos das contribuições pelos Fundos de Pensão e que as mesmas não possuem imunidade tributária, fazendo jus, ainda assim, ao pagamento da Contribuição Social sobre o Lucro Líquido (“CSLL”), por exemplo.

A exceção à essa regra, já mencionada, encontra-se prevista na Súmula 730 STF: "A imunidade tributária conferida a instituições de assistência social sem fins lucrativos pelo art. 150, VI, c, da Constituição, somente alcança as entidades fechadas de previdência social privada se não houver contribuição dos beneficiários".

A isenção do Pagamento do Imposto de Renda, previsto na Lei $11.053 / 2004$, não dispensa o contribuinte do cumprimento das obrigações acessórias, conforme previsto no art. 175 do CTN, e nem tampouco dispensa os Fundos de Pensão imunes de tais obrigações, uma vez que decorrem da lei e não das obrigações principais, conforme o art. $113, \S 2^{\circ}$, do CTN, explicita. 


\subsubsection{Regime aplicável para apuração do lucro nos Fundos de Pensão}

Não obstante as críticas, como a de José Eduardo Soares de Mello para quem a disponibilidade econômica estaria ligada ao dinheiro recebido por atividades ilícitas e, portanto, sem nenhuma tutela jurídica ${ }^{40}-$ os conceitos de disponibilidade econômica e jurídica explicitados são os que têm sido adotado majoritariamente pela doutrina e, nota-se, assemelham-se muito aos conceitos de Regime de Competência e Regime de Caixa.

No Regime de Competência, os direitos são registrados no momento em que o credor passa a lhe fazer jus. Por exemplo, contabiliza-se o valor da venda de um automóvel no momento da entrega do veículo e não de seu pagamento.

De acordo com o disposto no art. 274 do Decreto 3.000/1999, as empresas que estão sujeitas ao regime de tributação do Lucro Real utilizamse das regras da Lei 6.404/1974 para apuração de seu lucro líquido ${ }^{41}$.A Lei 6.404/1974, por sua vez, prescreve a utilização do Regime de Competência como modalidade hábil para a contabilização do patrimônio das sociedades anônimas ${ }^{42}$.

\footnotetext{
${ }^{40}$ MACHADO, Brandão. Estudos Sobre o Imposto de Renda (Em Memória de Henry Tilbery). Coordenação: Ives Gandra Martins. Editora Resenha Tributária Ltda.: São Paulo, Julho de 1994. P. 121.

${ }^{41}$ Art. 274. Ao fim de cada período de incidência do imposto, o contribuinte deverá apurar o lucro líquido mediante a elaboração, com observância das disposições da lei comercial, do balanço patrimonial, da demonstração do resultado do período de apuração e da demonstração de lucros ou prejuízos acumulados. $\S 1^{\circ} \mathrm{O}$ lucro líquido do período deverá ser apurado com observância das disposições da Lei no 6.404, de 1976.

(...)

${ }^{42}$ Art. 177. A escrituração da companhia será mantida em registros permanentes, com obediência aos preceitos da legislação comercial e desta Lei e aos princípios de contabilidade geralmente aceitos, devendo observar métodos ou critérios contábeis uniformes no tempo e registrar as mutações patrimoniais segundo o regime de competência.
} 
As empresas optantes do Lucro Presumido, são aquelas cuja receita bruta total no ano-calendário anterior tenha sido igual ou inferior a R \$ 78.000.000,00 ou a $\mathrm{R} \$ 6.500 .000,00$ multiplicado pelo número de meses de atividade do ano-calendário anterior, quando inferior a 12 (doze) meses. Conforme descrito no art. $7^{\circ}$ da Lei $12.814 / 2013^{43}$.

Algumas empresas, porém, estão excluídas do da tributação pelo Lucro Presumido em decorrência do art. 14 da Lei 9.718/1998, por exemplo, as instituições bancárias, que tenham rendimentos oriundos do exterior ou que usufruam de benefícios fiscais, como a isenção ${ }^{44}$.

\footnotetext{
${ }^{43}$ Art. $7^{\circ} \mathrm{O}$ caput do art. 13 e o inciso I do art. 14 da Lei $\mathrm{n}^{\circ} 9.718$, de 27 de novembro de 1998, passam a vigorar com a seguinte redação:“Art. 13. A pessoa jurídica cuja receita bruta total no ano-calendário anterior tenha sido igual ou inferior a $\mathrm{R} \$ 78.000 .000,00$ (setenta e oito milhões de reais) ou a $\mathrm{R} \$ 6.500 .000,00$ (seis milhões e quinhentos mil reais) multiplicado pelo número de meses de atividade do ano-calendário anterior, quando inferior a 12 (doze) meses, poderá optar pelo regime de tributação com base no lucro presumido.
}

"Art. 14. ..$(\mathrm{NR})$

I - cuja receita total no ano-calendário anterior seja superior ao limite de $\mathrm{R} \$$ 78.000.000,00 (setenta e oito milhões de reais) ou proporcional ao número de meses do período, quando inferior a 12 (doze) meses;

${ }^{44}$ Art.14. Estão obrigadas à apuração do lucro real as pessoas jurídicas:I - cuja receita total no ano-calendário anterior seja superior ao limite de $\mathrm{R} \$ 78.000 .000,00$ (setenta $\mathrm{e}$ oito milhões de reais) ou proporcional ao número de meses do período, quando inferior a 12 (doze) meses;

II - cujas atividades sejam de bancos comerciais, bancos de investimentos, bancos de desenvolvimento, caixas econômicas, sociedades de crédito, financiamento e investimento, sociedades de crédito imobiliário, sociedades corretoras de títulos, valores mobiliários e câmbio, distribuidoras de títulos e valores mobiliários, empresas de arrendamento mercantil, cooperativas de crédito, empresas de seguros privados e de capitalização e entidades de previdência privada aberta;

III - que tiverem lucros, rendimentos ou ganhos de capital oriundos do exterior;

IV - que, autorizadas pela legislação tributária, usufruam de benefícios fiscais relativos à isenção ou redução do imposto;

$\mathrm{V}$ - que, no decorrer do ano-calendário, tenham efetuado pagamento mensal pelo regime de estimativa, na forma do art. $2^{\circ}$ da Lei ${ }^{\circ}$ 9.430, de 1996;

VI - que explorem as atividades de prestação cumulativa e contínua de serviços de assessoria creditícia, mercadológica, gestão de crédito, seleção e riscos, administração de contas a pagar e a receber, compras de direitos creditórios resultantes de vendas mercantis a prazo ou de prestação de serviços (factoring).

VII - que explorem as atividades de securitização de créditos imobiliários, financeiros e do agronegócio. 
As empresas que optam pelo Lucro Presumido podem utilizar o Regime de Caixa para calcular sua receita bruta total, de acordo com o art. $13, \S 2^{\circ}$, da Lei 9.718/1998 ${ }^{45}$.

Essa possibilidade, porém, não abrange os Fundos de Pensão, uma vez que são beneficiários de isenção no que concerne ao Imposto de Renda. Então, sua tributação se dará sempre com base no Lucro Real.

\subsection{Com relação aos participantes ou assistidos}

Para os participantes e assistidos, os planos de benefícios são uma poupança de longo prazo e a política tributária protege este tipo de investimento da tributação na fase de capitalização, tributando apenas no momento seguinte, no qual os benefícios são distribuídos.

As contribuições vertidas para os planos de benefícios administrados por Fundos de Pensão, de 1989 a 1995, compunham a base de cálculo para efeito de cálculo de Imposto de Renda sobre a Pessoa Física ("IRPF"), apenas com o advento da Lei 9.250/1995 essa contradição foi corrigida e as contribuições passaram a não ser mais tributadas até um certo limite: $12 \%$ do total dos rendimentos computados na determinação da base de cálculo do imposto devido, para participantes e assistidos, e $20 \%$ do total dos salários dos empregados e da remuneração dos dirigentes da empresa, vinculados ao plano de benefícios.

\footnotetext{
${ }^{45}$ Art. 13. A pessoa jurídica cuja receita bruta total no ano-calendário anterior tenha sido igual ou inferior a $\mathrm{R} \$ 78.000 .000,00$ (setenta e oito milhões de reais) ou a $\mathrm{R} \$$ 6.500.000,00 (seis milhões e quinhentos mil reais) multiplicado pelo número de meses de atividade do ano-calendário anterior, quando inferior a 12 (doze) meses, poderá optar pelo regime de tributação com base no lucro presumido. (Redação dada pela Lei $n^{0}$ 12.814, de 2013)§ $1^{\circ}$ A opção pela tributação com base no lucro presumido será definitiva em relação a todo o ano-calendário.

$\S 2^{\circ}$ Relativamente aos limites estabelecidos neste artigo, a receita bruta auferida no ano anterior será considerada segundo o regime de competência ou de caixa, observado o critério adotado pela pessoa jurídica, caso tenha, naquele ano, optado pela tributação com base no lucro presumido.
} 
A incidência do IRPF ocorre na fase de percepção dos benefícios da poupança e a alíquota varia para cada tipo de plano. Nos planos de benefício definido, a tributação segue a tabela clássica de incidência e pode chegar a $27,5 \%$.

Já nos planos de contribuição definida e contribuição variável, o participante pode optar pela tabela acima, com alíquotas progressivas, ou pela tabela regressiva, em razão do tempo de aplicação, do art. $1^{\circ}$ da Lei $11.053 / 2004^{46}$.

Dessa forma, utilizando a tabela regressiva, a contribuição pode ir de $10 \%$ a $35 \%$, recomenda-se muita cautela ao escolher entre uma das duas tabelas, pois a opção é irretratável e irrevogável.

Atenta-se para o fato de como as contribuições são dedutíveis da base de cálculo do IRPF, os benefícios, na fase de sua percepção, serão tributados tanto no que concerne o rendimento das aplicações, quanto o capital vertido que está sendo devolvido.

\footnotetext{
${ }^{46}$ Art. $1^{\circ}$ É facultada aos participantes que ingressarem a partir de $1^{\circ}$ de janeiro de 2005 em planos de benefícios de caráter previdenciário, estruturados nas modalidades de contribuição definida ou contribuição variável, das entidades de previdência complementar e das sociedades seguradoras, a opção por regime de tributação no qual os valores pagos aos próprios participantes ou aos assistidos, a título de benefícios ou resgates de valores acumulados, sujeitam-se à incidência de imposto de renda na fonte às seguintes alíquotas:I - 35\% (trinta e cinco por cento), para recursos com prazo de acumulação inferior ou igual a 2 (dois) anos;

II - 30\% (trinta por cento), para recursos com prazo de acumulação superior a 2 (dois) anos e inferior ou igual a 4 (quatro) anos;

III - 25\% (vinte e cinco por cento), para recursos com prazo de acumulação superior a 4 (quatro) anos e inferior ou igual a 6 (seis) anos;

IV - 20\% (vinte por cento), para recursos com prazo de acumulação superior a 6 (seis) anos e inferior ou igual a 8 (oito) anos;

$\mathrm{V}-15 \%$ (quinze por cento), para recursos com prazo de acumulação superior a 8 (oito) anos e inferior ou igual a 10 (dez) anos; e

VI - 10\% (dez por cento), para recursos com prazo de acumulação superior a 10 (dez) anos.

$(\ldots)$
} 


\subsection{A responsabilidade tributária dos administradores de Fundos de}

\section{Pensão}

Os administradores são pessoalmente responsáveis por obrigações tributárias que decorram de atos praticados com excesso de poderes ou infração da lei, contrato social ou estatutos.

Então se o administrador, por exemplo, não entrega a declaração de rendimentos no fim do exercício social (como foi exposto, a isenção do Imposto de Renda não isenta os beneficiários das obrigações acessórias), ele responderá em substituição ao Fundo de Pensão que administra pela obrigação principal (multa) que surgirá pelo desobedecimento de obrigação acessória.

Essa regra parece bastante razoável, pois se foi o administrador em sua má conduta que seu causa à obrigação principal, não deverá aos participantes do fundo quitá-la com o dinheiro de sua aposentadoria.

A responsabilidade dos administradores de Fundos de Pensão é objetiva por infrações à legislação tributária, ou seja, independe de culpa. 


\section{CAPÍTULO 4 - A ADMINISTRAÇÃO DOS FUNDOS DE PENSÃO}

\subsection{Noções Gerais}

\subsubsection{Natureza jurídica dos Fundos de Pensão}

O Fundo de Pensão é uma pessoa jurídica de direito privado, apesar da inexistência de interesse econômico na atividade, ainda quando criada pela Administração Pública para administrar planos de benefícios custeados por ela ou por seus funcionários, de acordo com o exemplo elucidativo dado por Adacir Reis ${ }^{47}$, o Banco do Brasil pode ser uma empresa pública, mas o seu Fundo de Pensão, a Previ, é uma entidade privada.

O $\S 15$ do art. 40 da CRFB fala sobre "entidades fechadas de previdência complementar, de natureza pública", o que poderia suscitar algum debate sobre a natureza jurídica dos Fundos de Pensão.

Alexandre Brandão Henriques Maimoni $^{48}$, porém, explica que a natureza pública do Fundo de Pensão não se coaduna com o art. 202 da CRFB e com a própria estrutura da previdência complementar, devendo essa expressão ser interpretada no sentido de múnus público, assim como as entidades do setor público não estatal, entidades privadas que prestam serviços de interesse público. Este é o caso, por exemplo, das entidades paraestatais, como SESI, SESC, e SENAI.

\footnotetext{
${ }^{47}$ O patrocinador da entidade e de seus planos de benefícios pode ser estatal (uma empresa estatal, por exemplo), mas a entidade fechada de previdência complementar é privada, não obstante a ausência de finalidade lucrativa. Assim, o Banco do Brasil é estatal (tendo em vista que se trata de uma empresa de economia mista sob o controle da União), mas a Caixa de Previdência dos Funcionários do Banco do Brasil - Previ é uma entidade previdenciária privada, pertencente exclusivamente a seus associados. In REIS, Adacir. Curso Básico de Previdência Complementar. Editora Revista dos Tribunais: 2012, São Paulo. P. 22.

48 MAIMONI, Alexandre Brandão. A natureza jurídica dos fundos de pensão dos servidores públicos. Disponível em: < https://jus.com.br/artigos/5818/a-natureza-juridicados-fundos-de-pensao-dos-servidores-publicos/2>. Acesso em 23.05.2016.
} 


\subsubsection{Fundações ou sociedades civis}

Como prescreve o art. 31, $\S 1^{\circ}$, da LC 109/2001, os Fundos de Pensão organizam-se sob a forma de fundação ou de sociedade civil, sem fins lucrativos.

Fundações são acervos de bens colocado a serviço de uma causa. Os fins da sociedade devem figurar no estatuto e o art. 24 , § único, do CC define quais os possíveis, dentre eles: os religiosos, os morais, os culturais e os assistenciais. Os administradores da fundação podem, mediante deliberação de dois terços, alterar cláusulas do estatuto, desde que não contrariem os fins para os quais a entidade foi criada.

As sociedades civis, com o advento no Novo Código Civil, passaram a se chamar sociedades simples. Tais sociedades são aquelas que tem objeto diverso de atividade própria de empresário e, apesar de terem regras próprias, disciplinadas entre os arts. 997 a 1.038 do CC, podem adotar os modelos de sociedade em nome coletivo, sociedade em comandita simples, sociedade limitada e sociedade cooperativa.

\subsection{3. Órgãos da estrutura interna}

As LC 109/2001 e 108/2001, ao descrever a estrutura interna, no que tange à administração, dos Fundos de Pensão, estabelece um mecanismo de freios e contrapesos no qual cada um dos órgãos atua limitando os poderes do outro, de acordo com Adacir Reis ${ }^{49}$, esse mecanismo funciona da seguinte forma: "todo órgão estatutário é receptor e produtor (emissor) de informações, praticando atos que repercutirão dos demais".

\footnotetext{
${ }^{49}$ REIS, Adacir. Curso Básico de Previdência Complementar. Editora Revista dos Tribunais: 2012, São Paulo. P. 38.
} 
Os órgãos que a LC 109/2001 estabelece em sua redação como obrigatórios são o Conselho Deliberativo, a Diretoria Executiva e o Conselho Fiscal, mas é comum nos estatutos dos Fundos de Pensão multipatrocinadas a previsão de uma Assembleia Patrocinadora.

O estatuto dos Fundos de Pensão, que dispõe sobre a sua estrutura organizacional, bem como as suas posteriores modificações, dependerão de prévia e expressa autorização da Previc, como ordena o art. 33 da LC $109 / 2001$.

\subsection{Conselho Deliberativo}

Conselho Deliberativo é a instância máxima das decisões administrativas de um Fundo de Pensão e é responsável por formular as políticas gerais de administração da entidade. Suas competências são bem definidas em Fundos de Pensão patrocinadas pela Administração Pública ${ }^{50}$.

No caso das demais Fundos de Pensão, regidos exclusivamente pela LC 109/2001, não há previsão legal de suas competências, mas Adacir Reis $^{51}$ revela que os estatutos costumam atribuir-lhes as seguintes: "a definição da política geral de investimentos, a autoridade para alterar estatutos ou regulamentos (com posterior apreciação e aprovação da Previc), a autorização para operações de maior vulto, a aprovação de ingresso ou retirada de patrocinadores (e instituidores) e a apreciação de recursos interpostos contra decisões da diretoria administrativa”.

As regras para composição do Conselho Deliberativo são diferentes em se tratando dos Fundos de Pensão patrocinadas ou instituídas pela Administração Pública ou por particulares. No caso destas, não há número máximo de integrantes, porém um terço das vagas deverão ser preenchidas

\footnotetext{
${ }^{51}$ REIS, Adacir. Curso Básico de Previdência Complementar. Editora Revista dos Tribunais: 2012, São Paulo. P. 39.
} 
por representantes dos participantes e assistidos, como determina o art. 35, $\S 1^{\circ}$, da LC 109/2001.

Por outro lado, os Conselhos Deliberativos de Fundos de Pensão patrocinadas ou instituídas pela Administração Pública são formados por, no máximo, seis membros, sendo uma metade preenchida por indicações dos patrocinadores e instituidores e a outra por representantes dos participantes e assistidos. Cabendo aos patrocinadores e instituidores a indicação do presidente, que terá o voto de qualidade.

\subsection{Diretoria Executiva}

A Diretoria Executiva é o órgão que detalha e executa as políticas de administração já determinadas pelo Conselho Deliberativo. Ela é responsável pela administração cotidiana das atividades da entidade e também da gestão dos ativos garantidores dos planos e seus passivos.

A Diretoria Executiva costuma ser formada, segundo Adacir Reis ${ }^{52}$, por "um presidente ou diretor-superintendente, um diretor de investimentos ou financeiro, um diretor de benefícios ou de seguridade e um diretor de administração, embora tal composição dependa do porte da entidade, volume de recursos administrados e grau de complexidade de seus planos de benefícios". Em Fundos de Pensão patrocinados ou instituídos pela Administração Pública, o limite do número de Diretores é seis.

Dentre os Diretores do Fundo de Pensão, deve ser designado um, que será responsável pelas aplicações dos recursos dos planos de benefícios da entidade, de acordo com o disposto no art. 35, § 5, da LC 109/2001 e art. $7^{\circ}$ da Resolução $C M N n^{\circ}$ 3.792. Também será designado para cada plano de benefícios Diretor responsável, conforme Anexo 3 da Resolução CGPC n ${ }^{\circ}$ $18 / 2006$.

\footnotetext{
${ }^{52}$ REIS, Adacir. Curso Básico de Previdência Complementar. Editora Revista dos Tribunais: 2012, São Paulo. P. 40.
} 
A Diretoria Executiva age de acordo com o plano de investimentos definido previamente pelo Conselho Deliberativo e seus atos são sujeitos a uma análise, em momento posterior, pelo Conselho Fiscal.

É dever do Diretor se qualificar. Diz Adacir Reis ${ }^{53}$ :

É indispensável que os membros do Conselho Deliberativo, Diretoria Executiva e Conselho Fiscal sejam tecnicamente qualificados para suas atribuições, pouco importando se são eleitos pelos participantes ou indicados pelos patrocinadores.

Nesse sentido, a Resolução CMN 3.792, por meio de seu art. $8^{\circ}$, exige que os administradores de Fundos de Pensão sejam certificados e o art. 35 da LC 109/2001 estabelece uma série de outros requisitos, por exemplo, os membros da Diretoria Executiva devem ter formação superior.

O dever de se qualificar é intrínseco ao Dever de Diligência, que, de acordo com a doutrina, se subdivide em diversos outros deveres. Nesse sentido, tem-se o entendimento de Nelson Eizirik ${ }^{54}$.

(...) o administrador deve ter ou adquirir os conhecimentos minimos sobre as atividades da companhia e a competência necessária ao desempenho de suas funções, com capacidade técnica par tomar decisões de maneira refletida e responsável. Assim, se o administrador não possui conhecimentos mínimos que lhe permitam dirigir os negócios sociais, não deve aceitar o cargo.

\subsection{Conselho Fiscal}

O Conselho Fiscal é o órgão responsável por promover a fiscalização de contas da administração dos Fundos de Pensão e seus planos de benefícios. É obrigatória a sua existência em tais entidades, como prescreve o art. 35 da LC 109/2001.

Não há limitação para o número de membros do Conselho Fiscal de Fundos de Pensão patrocinados por entidade privada, porém um terço de

\footnotetext{
53 REIS, Adacir. Curso Básico de Previdência Complementar. Editora Revista dos Tribunais: 2012, São Paulo. P. 41.

${ }^{54}$ EIZIRIK, Nelson. A lei das S/A comentada: artigos 121 a 188. São Paulo: Quartier Latin, 2011. v.2. p. 353
} 
seus membros será composto por representantes dos participantes e assistidos.

No caso das entidades patrocinadas ou instituídas pela Administração Pública, o art. 15 da LC 108/2001 ordena que o Conselho Fiscal seja composto por quatro membros, sendo metade destas indicações dos patrocinadores e instituidores e a outra metade por representantes dos participantes e assistidos. Cabendo aos últimos a indicação do presidente, que terá o voto de qualidade. 


\section{CAPÍTULO 5 - RESPONSABILIDADE DOS ADMINISTRADORES DE FUNDOS DE PENSÃO}

\subsection{Da aplicação dos deveres fiduciários dos administradores de sociedades anônimas à análise da responsabilidade dos administradores de Fundos de Pensão}

O art. 1.011 da Seção III do Capítulo I do Subtítulo II do Código Civil - que trata das sociedades simples - estabelece aos administradores dever similar ao previsto no art. 153 da Lei 6.404/1976 55 .

As Sociedades Seguradoras, diversamente dos Fundos de Pensão, são constituídas sob a forma de sociedade anônima obrigatoriamente, conforme diz o art. 36 da LC 109/2001 ${ }^{56}$.

Devido ao objetivo das duas entidades e à similitude do art. 1.011 do CC e 153 da Lei 6.404/1976, parece que a construção doutrinária para balizar a responsabilidade do administrador de sociedades anônimas, em nome da interpretação sistemática da lei, deve também ser utilizada para os administradores de Fundos de Pensão constituídas sob a forma de sociedade simples.

No caso das fundações, o art. 62 do CC estabelece que o instituidor da fundação deve, em seu estatuto, especificar o fim a que ela se destina e, se quiser, dispor sobre a maneira de administrá-la. Contudo, não se pode

\footnotetext{
${ }^{55}$ Art. 1.011. O administrador da sociedade deverá ter, no exercício de suas funções, o cuidado e a diligência que todo homem ativo e probo costuma empregar na administração de seus próprios negócios.

(...)

${ }^{56}$ Art. 36. As entidades abertas são constituídas unicamente sob a forma de sociedades anônimas e têm por objetivo instituir e operar planos de benefícios de caráter previdenciário concedidos em forma de renda continuada ou pagamento único, acessíveis a quaisquer pessoas físicas.

Parágrafo único. As sociedades seguradoras autorizadas a operar exclusivamente no ramo vida poderão ser autorizadas a operar os planos de benefícios a que se refere o caput, a elas se aplicando as disposições desta Lei Complementar.
} 
perder de vista, que as fundações estão afetadas aos fins previstos no seu estatuto.

Sendo o fim da fundação assistencial, no sentido de administrar planos de benefícios, esta deve seguir as regras de diligência condizentes com a função exercitam, sob pena de desvio de finalidade. Como diz José Eduardo Sabo Paes ${ }^{57}$ :

Os fins ditados pelo instituidor também não podem ser desvirtuados ou entregues ao arbitrio dos administradores, uma vez que em sede fundacional não existe a liberalidade de modificações ou alterações dos próprios fins, mesmo implicitamente, sob pena d caracterizar o denominado desvio de finalidade.

Dessa forma, os subdeveres fiduciários construídos pela doutrina para balizar a atuação dos administradores de sociedades anônimas aplicase aos administradores de Fundos de Pensão, não importando se as mesmas se constituem sob a forma de sociedade simples ou fundação.

\subsection{Os deveres fiduciários dos administradores de sociedades anônimas}

\subsubsection{Dever de Diligência}

Trata-se, para muitos, do principal dever fiduciário dos administradores, para Luis Felipe Spinelli58 é o dever de "cumprimento das funções pelo administrador com dedicação, atenção, zelo e cuidado". A lei não especifica o que é agir de forma diligente, por isso as condutas devem ser analisadas individualmente, conforme o caso concreto.

A análise do conceito de diligência perpassa pela indagação de como alguns outros administradores agiriam em determinada situação. Para isso, aprecia-se condutas de formas isoladas, subdividindo o Dever de Diligência em cinco outros deveres brevemente explicados a seguir.

\footnotetext{
${ }^{57}$ PAES, Eduardo Sabo. Fundações e Entidades de Interesse Social, Ed. Brasília Jurídica, $3^{\text {a }}$ edição. P. 199 e 229.

58 SPINELLI, Luis Felipe. Conflito de Interesses na Administração da Sociedade Anônima. São Paulo: Malheiros Editores, 2012. P. 104.
} 
O dever de qualificar-se, exemplificado pelo caso Francis vs United Jersey Bank, refere-se ao dever de o administrador buscar conhecimentos que deva ter ou adquirir para as suas funções; o dever de bem administrar, consistente no dever de o administrador atuar com vistas à consecução do objeto social da empresa; o dever de se informar, presente no caso Smith vs. van Gorkom, é o dever de o administrador buscar informações acerca dos negócios que participa; o dever de investigar consiste em analisar criticamente as informações fornecidas; e, por último, o dever de vigiar se realiza no monitoramento constante das atividades sociais.

Para a análise do descumprimento desses deveres, utiliza-se a regra do business judgement rule é definida no caso Aronson v. Lewis como "uma presunção que, ao realizar negócios, gozam os administradores de que agiram de forma honesta, de boa fé e bem informados, acreditando ter sido a decisão tomada no melhor interesse da companhia". Dessa forma, o ônus de prova fica com o autor que queira responsabilizar os administradores.

\subsubsection{Dever de Lealdade}

Nos Estados Unidos, afirma-se quase de maneira absoluta a existência de dois deveres fiduciários: o Dever de Diligência (duty of care) e o Dever de Lealdade (duty of loyalty), sendo os outros deveres apenas desdobramentos desses dois.

O Dever de Lealdade traz a obrigação de respeito aos bens da companhia que administra, devendo o administrador servir a ela e não se servir dela ${ }^{59}$.

59 SPINELLI, Luis Felipe. Conflito de Interesses na Administração da Sociedade Anônima. São Paulo: Malheiros Editores, 2012. P. 104. 


\subsubsection{Dever de Informar}

O Dever de Informar possibilita a tomada de decisão por parte dos acionistas e o exercício de alguns de seus direitos, além de ser importante para as decisões dos investidores e da eficiência do próprio mercado.

Segundo Spinelli ${ }^{60}$, consiste, na prática, em identificar determinadas situações de perigo e nivelar o conhecimento dos acionistas e investidores em geral, por isso está intimamente ligado com a prática do insider trading.

\subsubsection{Dever de Obediência}

Este dever fiduciário traz aos administradores a obrigação de obedecer ao estatuto social da companhia, não podendo seus atos ultrapassarem os limites do objeto social.

Alguns autores compreendem esse dever de uma forma mais ampla, afirmando que os atos dos administradores não podem estar em desconformidade com o Direito, de modo geral.

Nesse sentido, tem-se os caso norte-americano Miller vs. American Telephone \& Telegraph Co., onde não se reconheceu a aplicação do business judgement rule a um ato de remição de dívida da conta de telefone do Partido Democrata. Nesse caso, a Corte compreendeu que havia uma doação indireta, violando a legislação eleitoral.

60 SPINELLI, Luis Felipe. Conflito de Interesses na Administração da Sociedade Anônima. São Paulo: Malheiros Editores, 2012. P.120/121. 


\subsection{Transações entre partes relacionadas no âmbito dos Fundos de Pensão}

\subsubsection{As transações entre partes relacionadas e o conflito de interesses}

A Deliberação CVM nº 642 aprovou o Comitê de Pronunciamentos Contábeis $\mathrm{n}^{\circ} 5$ (R1) (“CPC 5”) no qual define transação com partes relacionadas como "a transferência de recursos, serviços ou obrigações entre uma entidade que reporta a informação e uma parte relacionada, independentemente de ser cobrado um preço em contrapartida".

O CPC 5 expõe um rol de hipóteses em que as pessoas são consideradas partes relacionadas com a entidade que lhe reporta informação, uma delas é se "a entidade é um plano de beneficio pósemprego cujos beneficiários são os empregados de ambas as entidades, a que reporta a informação e a que está relacionada com a que reporta a informação. Se a entidade que reporta a informação for ela própria um plano de beneficio pós-emprego, os empregados que contribuem com a mesma serão também considerados partes relacionadas com a entidade que reporta a informação".

A redação, embora confusa, parece exprimir que, caso um Fundo de Pensão administre planos de benefícios exclusivamente para seus próprios funcionários e para os funcionários de determinada empresa patrocinadora, ela será considerada parte relacionada com relação a empresa patrocinadora e com os seus funcionários.

A norma parece pretender excluir de sua incidência os Fundos de Pensão multipatrocinados, justamente para evitar que estes fiquem sem opções para investir, tendo em vista a pluralidade de partes relacionadas que teria. 
Operações entre partes relacionadas possuem alto potencial para conflito de interesses, por isso, é necessário um cuidado particular em sua análise.

$\mathrm{O}$ art. $115, \S 1^{\circ}$ da LSA, estabelece casos nos quais fica vedado ao acionista exercer seu direito de voto. Dentre outras, a lei societária cita a ocorrência de conflito de interesses.

Doutrina e jurisprudência se dividem em duas correntes para a análise do conflito de interesses, são elas chamadas: formal e material. $\mathrm{Na}$ primeira, o impedimento se configura a priori, quando vislumbrada a situação de conflito de interesses, o acionista ficará impedido de exercer o seu direito de voto; na segunda, o impedimento ocorre apenas depois de realizado um juízo a respeito da qualidade do voto: se era compatível ou não com o interesse social.

A regra de impedimento do conflitado também está prevista para os administradores, no art. 156, da LSA. Diz em sua redação: "É vedado ao administrador intervir em qualquer operação social em que tiver interesse conflituante com o da companhia".

Ou seja, em matérias que envolvam transações com os patrocinadores, administradores indicados por eles poderão ficar impedidos de participar.

\subsubsection{As transações entre partes relacionadas e o Dever de Diligência}

Ao negociar com uma parte relacionada, os administradores precisam de cautela redobrada, isso fez com que a jurisprudência americana buscasse novos parâmetros para avaliar o Dever de Diligência nessas situações. 
A Court of Chancery decidiu no caso Sinclair Oil Corp. v. LEVIEN que o business judgement rule não era a regra mais apropriada para avaliar a culpabilidade das ações dos administradores em transações com partes relacionadas, mas sim o instrinsic fairness test, que impõe ao administrador o ônus de provar que sua decisão foi justa para a companhia. Transformando a responsabilidade subjetiva em presumida.

\subsection{Fundamentos da responsabilidade civil dos administradores}

\subsubsection{Casos de responsabilidade subjetiva}

O art. 63 da LC 109/2001 dispõe sobre a responsabilização dos administradores de fundos de pensão em decorrência dos prejuízos causados por atos de ação ou omissão ${ }^{61}$.

A referida norma não determina se a responsabilidade dos administradores é objetiva ou subjetiva, sendo a responsabilidade subjetiva a regra do Código Civil.

O fundo, de uma forma geral, tem como fundamento de sua existência a possibilidade de, através da divisão de custos para a contratação de uma gestão qualificada dos ativos e o aumento das oportunidades de investimento, com um maior valor disponível para aplicações, o investidor perceber rendimentos superiores ao que teria chances aplicando o seu dinheiro de forma isolada. Conforme ensina Tatiana Nogueira da Rocha ${ }^{62}$ :

61 Art. 63. Os administradores de entidade, os procuradores com poderes de gestão, os membros de conselhos estatutários, o interventor e o liquidante responderão civilmente pelos danos ou prejuízos que causarem, por ação ou omissão, às entidades de previdência complementar.

Parágrafo único. São também responsáveis, na forma do caput, os administradores dos patrocinadores ou instituidores, os atuários, os auditores independentes, os avaliadores de gestão e outros profissionais que prestem serviços técnicos à entidade, diretamente ou por intermédio de pessoa jurídica contratada.

${ }^{62}$ DOTTA, Ricardo Montenegro. A responsabilidade dos administradores de fundos de investimentos no novo código civil: uma abordagem da indústria dos fundos de 
apesar de a rentabilidade em nenhum momento ser garantida pelo administrador dos fundos de investimento, deve ser perseguida apesar dos riscos que possam existir. (...) A rentabilidade da carteira de ativos do fundo depende da sua distribuição entre títulos seguros e de baixo rendimento e outros de mais risco e maior rendimento. A arte de ser administrador está em equilibrar rentabilidade e risco (...)

A exposição da professora traz um princípio importante da administração dos fundos: a diversificação de investimentos. Uma gestão prudente, jamais irá "apostar todas as fichas em apenas um cavalo". Por isso mesmo, a Resolução CMN no 3.792 traz diversos limites máximos para aplicação dos recursos dos planos de benefícios, que serão objeto do próximo capítulo assim como a Instrução CVM no 555 traz para os fundos de investimento.

Segundo Eduardo Montenegro Dotta ${ }^{63}$, a análise do risco e da rentabilidade dos investimentos pelo fundo não pode ser feito levando em consideração apenas os rendimentos históricos do mesmo, uma vez que não é garantido que aqueles investimentos obtenham o mesmo resultado que em anos anteriores. Para o referido autor, esta análise jamais poderá de analisar as condições macroeconômicas do momento.

Os principais riscos envolvidos na atividade são, na visão de Eduardo Montenegro Dotta ${ }^{64}$, o risco de crédito, o risco de mercado, o risco de liquidez, o risco operacional, o risco legal e outros riscos como riscos políticos, de força maior ou fora-do-balanço.

O risco de crédito é a possibilidade de a prestação, principal e acessória, não serem integralmente adimplidas pelos devedores na data combinada.

investimento, voltada para a natureza da responsabilidade de seus administradores, sob a ótica dos novos princípios orientadores do direito privado e da regulamentação do setor. São Paulo: Textonovo, 2005. P. 99.

${ }^{63}$ Op. cit. P. 117.

${ }^{64}$ Loc. cit. 
O risco de mercado trata-se da possibilidade de, em razão de fatores econômicos, como oscilações nos preços de commodities, ações, taxa de juros, os investimentos não gerarem o retorno esperado.

$\mathrm{O}$ risco de liquidez é relativo à falta de demanda pelos ativos que compõem o patrimônio do fundo, o que pode obrigar o gestor, na hipótese de liquidação do fundo, por exemplo, a vendê-lo por preço inferior ao seu valor.

O risco operacional é a probabilidade de falhas nos controles internos do fundo, diz respeito ao elemento humano das atividades.

O risco legal está relacionado à mudança de interpretação acerca da regularidade de uma operação ou à decisões desfavoráveis no âmbito judicial.

Por último, os riscos políticos são relacionados à desestabilização do regime político, como no caso de guerra, os riscos de força maior são conexos à grandes enchentes, terremotos, eventos naturais que possam prejudicar a atividade e os riscos fora-do-balanço são bem exemplificadas por aqueles decorrentes das garantias concedidas, como o aval e a fiança.

Com todos esses riscos envolvidos na atividade exercida pelos fundos, poder-se-ia alegar que as atividades desenvolvidas pelos fundos são atividades de risco e, portanto, regido pelo parágrafo único do art. 927 do $\mathrm{CC}^{65}$.

Isso significa dizer que a reponsabilidade civil dos administradores de fundos de pensão ou de fundos de investimento seria objetiva. A doutrina, porém, é consoante em rechaçar essa teoria.

\footnotetext{
${ }^{65}$ Art. 927. Aquele que, por ato ilícito (arts. 186 e 187), causar dano a outrem, fica obrigado a repará-lo.

Parágrafo único. Haverá obrigação de reparar o dano, independentemente de culpa, nos casos especificados em lei, ou quando a atividade normalmente desenvolvida pelo autor do dano implicar, por sua natureza, risco para os direitos de outrem.
} 
Para Glauber Moreno Talavera ${ }^{66}$, a reponsabilidade objetiva não é passível de ser aplicada aos administradores, pois a própria atividade é uma atividade de risco, que são todos manifestos. Os participantes, ao voluntariamente participarem de um plano de benefícios, acordam com todos os riscos da atividade e se dispõem a corrê-los.

O que se subtrai e extirpa terminantemente qualquer resquício de possibilidade de que os fundos estejam sob o efeito regulatório do parágrafo único do art. 927 é que, apesar de a atividade desenvolvida pelos administradores de fundos de investimento ser atividade normalmente de risco, os riscos são manifestos e os investidores subscrevem termos de responsabilidade, no qual manifestam ciência irrestrita das possibilidades de perda de capital e, ainda, de eventual necessidade de aporte de capital em casos extremos de perda, que podem acontecer.

Para o autor, o administrador apenas será punido na esfera civil se, em realizando operações em desacordo com o previsto no regulamento, essas operações acarretarem prejuízos.

De acordo com Sílvio de Salvo Venosa ${ }^{67}$, o fundamento original da responsabilidade era exclusivamente subjetivo. Essa posição foi adotada pelos códigos do passado quase unanimemente. Os tribunais, contudo foram percebendo que a noção estrita da culpa aplicada de forma rigorosa deixaria uma série de situações de dano sem ressarcimento.

Para atender necessidades sociais, a jurisprudência ampliou o conceito de culpa, daí ganhar espaço o conceito de responsabilidade sem culpa. Noções de risco e garantia ganham espaço para substituir a culpa, nesse sentido, destaca-se a teoria do risco proveito e a teoria do risco criado,

\footnotetext{
${ }^{66}$ DOTTA, Ricardo Montenegro. A responsabilidade dos administradores de fundos de investimentos no novo código civil: uma abordagem da indústria dos fundos de investimento, voltada para a natureza da responsabilidade de seus administradores, sob a ótica dos novos princípios orientadores do direito privado e da regulamentação do setor. São Paulo: Textonovo, 2005. P. 133.

${ }^{67}$ VENOSA, Sílvio de Salvo. Direito Civil: responsabilidade civil: v. 4. 10. ed. São Paulo: Atlas, 2010.
} 
sendo a segunda mais abrangente que a primeira. Nas palavras de Caio Mário da Silva Pereira ${ }^{68}$ :

A teoria do risco criado importa em ampliação do conceito de risco proveito. Aumenta os encargos do agente, é; porém, mais equitativa para vítima, que não tem de provar que o dano resultou de uma vantagem ou de um benefício obtido pelo causador do dano. Deve este assumir as consequências de sua atividade.

A sentença proferida pelo juiz Ricardo Coimbra da Silva Starling Barcellos no Processo no 0368890-32.2008.8.19.0001, em 01.03.2011, é bem didática nesse sentido, diz o magistrado que haverá obrigação de reparar um dano sempre que a atividade desenvolvida trazer, por sua natureza, rico para direito de outrem.

(...) É caso de responsabilidade civil objetiva em razão do risco criado, nos termos do art. 927, parágrafo único, do CC, in verbis: Art. 927, p.ú., CC: Haverá obrigação de reparar o dano, independentemente de culpa, nos casos especificados em lei, ou quando a atividade normalmente desenvolvida pelo autor do dano implicar, por sua natureza, risco para o direito de outrem. A aplicação do referido dispositivo se dá porque, em que pese tratar-se de pessoa jurídica prestadora de serviço público, não se pode considerar o autor como um terceiro na relação por eles estabelecida, não sendo caso, portanto, de aplicação do art. 37, $\S 6^{\circ}$, CRFB. Não se pode negar, por outro lado, que a empresa ré, em sua estação de tratamento, não desenvolva atividade altamente perigosa à saúde. Devem ser tomadas, por isso, todas as medidas adequadas para proteger tanto seus funcionários quanto eventuais visitantes do contato com o esgoto. Assim, a partir do momento em que a empresa ré autoriza a entrada de visitantes em suas dependências, passa ela a ser responsável pela integridade física dos mesmos.

(Grifou-se)

Importante notar que, no caso dos fundos, a administração realizada por eles não implica novos riscos aos direitos dos poupadores, a própria realização de investimento de capital é uma atividade de risco e os administradores de fundos nada mais fazem que mitigar esses riscos, que seriam muito maiores caso os participantes dos Fundos de Pensão resolvessem por conta própria aplicar os seu dinheiro no mercado de ações ou em quaisquer outros investimentos, alvos das atividades dos fundos.

\footnotetext{
${ }^{68}$ PEREIRA, Caio Mário da Silva. Responsabilidade civil. Rio de Janeiro: Forense, 2001.
} Pg. 285. 
Eduardo Montenegro Dotta ${ }^{69}$ alerta para o fato de que a aplicação da responsabilidade objetiva na indústria de fundos desmantelaria toda a indústria de atividades de investimento, fazendo com que o poupador não tenha onde aplicar o seu resultado superavitário e que as empresas tenham reduzidas oportunidades de financiamento.

\begin{abstract}
Além de implicar o desmantelamento da indústria dos fundos, o que obviamente não corresponde à intelecção oriunda da correta exegese da sistemática civil vigente - qual seja a de emperrar, via responsabilidade civil objetiva, o desenvolvimento de atividades econômicas relevantes - produz efeitos funestos para os próprios poupadores, que terão reduzidas as possibilidades de empregar rentabilidade às suas economias, para a mobilidade da poupança nacional, como também para a própria higidez do sistema financeiro nacional.
\end{abstract}

Esse é um importante ponto a se pesar na hora de decidir sobre qual das teorias deve-se aplicar à responsabilidade dos administradores de fundos e deve ser levado em consideração pelo julgador. Alonso Freire ${ }^{70}$ diz, sintetizando o pensamento de Oliver Wendell Holmes Jr. explica a necessidade da utilização de indicadores econômicos nas decisões judiciais. Se o Direito deseja servir como um instrumento de bem-estar social, ele deve buscar o melhor para todos, ou seja, o que gera maior retorno.

(...) O Direito deveria ser um instrumento real de transformação da sociedade com vistas ao bem-estar social de todos. É por essa razão que ele considerava o juiz como um legislador intersticial.

Em sua opinião, era inegável, ou melhor, desejável que o Direito se modificasse para adaptar-se a mudanças de opinião. Ele também defendia que essas mudanças não poderiam ser obstruídas pelo cego respeito a princípios antes aceitos como frutos da razão humana, já que a razão é uma competência instrumental. $O$ Direito e seus conceitos abstratos, portanto, não deveriam ser obstáculos à transformação social. Pelo contrário, o Direito deveria ser considerado um meio de transformação.

\footnotetext{
${ }^{69}$ DOTTA, Ricardo Montenegro. A responsabilidade dos administradores de fundos de investimentos no novo código civil: uma abordagem da indústria dos fundos de investimento, voltada para a natureza da responsabilidade de seus administradores, sob a ótica dos novos princípios orientadores do direito privado e da regulamentação do setor. São Paulo: Textonovo, 2005. P. 136.

70 FREIRE, Alonso. O Pêndulo de Posner. Disponível em: $<$ http://revistapensamentojuridico.fadisp.com.br/ojs/index.php/pensamentojuridico/article /download/21/37>. Acesso em: 22.05.2016.
} 


\subsubsection{Casos de responsabilidade presumida}

Quanto aos administradores indicados para responder civil e criminalmente pela gestão do fundo, Eduardo Montenegro Dotta ${ }^{71}$ explica que a sua responsabilidade também é subjetiva, todavia a culpabilidade é presumida. A razão para isso é óbvia: se o administrador deve cuidar de um setor específico de fundo, presume-se que ele sabe de todas as coisas que acontece ali, aquiescendo com o erro, e, se ele não sabe, está sendo negligente, o que caracteriza a culpa.

Desta forma, aos administradores indicados caberá a prova de ausência de dolo ou culpa nas suas ações responsáveis por danos ao patrimônio dos planos de benefícios. Pode-se aplicar o entendimento para todos os casos em que há indicação de administrador responsável, por exemplo, o diretor referido no Anexo 3 da Resolução CGPC nº 18/2006.

Além desses casos, pode-se aplicar a responsabilidade presumida em âmbito civil para os casos em que haja transações entre partes relacionadas, ensejando a aplicação do intrinsic fairness test como método de análise do padrão de conduta.

\subsubsection{Casos de responsabilidade objetiva}

A responsabilidade objetiva dos Fundos de Pensão quanto aos danos sofridos por participantes de planos de benefícios, advém da aplicação do art. 14, caput, do Código de Defesa do Consumidor ${ }^{72}$ a tais relações, conforme permitido pela Súmula 563 do STJ.

\footnotetext{
${ }^{71}$ DOTTA, Ricardo Montenegro. A responsabilidade dos administradores de fundos de investimentos no novo código civil: uma abordagem da indústria dos fundos de investimento, voltada para a natureza da responsabilidade de seus administradores, sob a ótica dos novos princípios orientadores do direito privado e da regulamentação do setor. São Paulo: Textonovo, 2005. P. 136.

${ }^{72}$ Art. 14. O fornecedor de serviços responde, independentemente da existência de culpa, pela reparação dos danos causados aos consumidores por defeitos relativos à prestação dos serviços, bem como por informações insuficientes ou inadequadas sobre sua fruição e riscos.
} 
De acordo com a redação do referido artigo, o fornecedor de serviços responde independentemente de culpa em casos de defeitos relativos à prestação dos mesmos.

No parágrafo primeiro ${ }^{73}$ do dispositivo já referido é exposto o conceito de serviço defeituoso. Diz ele que o serviço é defeituoso quando não oferece a segurança que era legitimamente esperada dele.

A responsabilidade civil objetiva do fundo pode ocorrer quando os investimentos são realizados em termos que produzem riscos acima dos permitidos em lei ou acima dos que os participantes concordaram, por exemplo, se seus administradores realizam investimentos que extrapolam o risco que os participantes concordaram em assumir ou se o membro da Diretoria-Executiva que realizou o investimento não tinha nível superior.

Também se um Fundo de Pensão, na gestão de seus ativos, descumpre os limites impostos por atos das entidades reguladores, como a Resolução CMN 3.792, e causa danos aos participantes ou assistidos, estarse-á diante de uma hipótese de responsabilidade objetiva.

Embora a responsabilidade objetiva seja com relação ao Fundo de Pensão, verifica-se a aplicação do art. $27, \S 5^{\circ}$, do Código de Defesa do Consumidor, que trata da teoria menor da desconsideração da personalidade jurídica.

Para o STJ, pouco importa se o administrador era sócio ou não da sociedade que teve a sua personalidade desconsiderada, a decisão judicial pode alcançar o seu patrimônio para obter o ressarcimento dos

\footnotetext{
${ }^{73} \S 1^{\circ}$ O produto é defeituoso quando não oferece a segurança que dele legitimamente se espera, levando-se em consideração as circunstâncias relevantes, entre as quais:

I - sua apresentação;

II - o uso e os riscos que razoavelmente dele se esperam;

III - a época em que foi colocado em circulação.
} 
prejudicados. Nesse sentido, tem-se a decisão do REsp: 1266666 SP 2009/0196940-9, relatado pela Ministra Nancy Andrighi:

\begin{abstract}
PROCESSO CIVIL. FALENNCIA. EXTENSÃO DE EFEITOS. POSSIBILIDADE.PESSOAS FÍSICAS. ADMINISTRADORES NÃO-SÓCIOS. GRUPO ECONÔMICO.DEMONSTRAÇÃO. DESCONSIDERAÇÃO DA PERSONALIDADE JURIDICA. CITAÇÃOPRÉVIA. DESNECESSIDADE. AÇÃO REVOCATÓRIA. DESNECESSIDADE. 1. Em situação na qual dois grupos econômicos, unidos em torno de um propósito comum, promovem uma cadeia de negócios formalmente lícitos mas com intuito substancial de desviar patrimônio de empresa em situação pré-falimentar, é necessário que o Poder Judiciário também inove sua atuação, no intuito de encontrar meios eficazes de reverter as manobras lesivas, punindo e responsabilizando os envolvidos. 2. É possível ao juízo antecipar a decisão de estender os efeitos de sociedade falida a empresas coligadas na hipótese em que, verificando claro conluio para prejudicar credores, há transferência de bens para desvio patrimonial. Inexiste nulidade no exercício diferido do direito de defesa nessas hipóteses. 3. A extensão da falência a sociedades coligadas pode ser feita independentemente da instauração de processo autônomo. A verificação da existência de coligação entre sociedades pode ser feita com base em elementos fáticos que demonstrem a efetiva influência de um grupo societário nas decisões do outro, independentemente de se constatara existência de participação no capital social. 4 . O contador que presta serviços de administração à sociedade falida, assumindo a condição pessoal de administrador, pode ser submetido ao decreto de extensão da quebra, independentemente de ostentar a qualidade de sócio, notadamente nas hipóteses em que, estabelecido profissionalmente, presta tais serviços a diversas empresas, desenvolvendo atividade intelectual com elemento de empresa. 5. Recurso especial conhecido, mas não provido.

(Grifou-se)
\end{abstract}

Se o patrocinador submete-se às mesmas regras de diligência que o administrador do Fundo de Pensão, conforme será demonstrado no próximo capítulo, e possui o dever se fiscalizar a administração, zelando pelo cumprimento dos padrões de segurança dos investimentos dos Fundos de Pensão, então será possível a aplicação da desconsideração da personalidade jurídica também para atingir o patrimônio dele.

Por exemplo, se os investimentos realizados pela Petros extrapolarem os limites de aplicação exigidos para o plano de benefícios que administra, os funcionários que tiveram suas aposentadorias frustradas por esses investimentos poderão buscar seu ressarcimento no patrimônio da própria Petrobrás. 


\subsection{Fundamentos da responsabilidade administrativa}

Quanto à responsabilidade administrativa, o art. 65 da LC 109/2001 traz uma norma "guarda-chuva", trata-se das penalidades a serrem aplicadas no caso de descumprimento de qualquer norma da LC 109/2001 e seus regulamentos que já não tenha uma penalidade específica cominada.

Essa penalidade pode ser de advertência, suspensão do exercício pelo prazo de até 180 dias e inabilitação de 2 a 10 anos, observado o caso e a gravidade $^{74}$.

\section{Conforme o Parecer $\mathrm{n}^{\mathrm{o}}$ 52/2013/PF-PREVIC/PGF/AGU ${ }^{75}$, de} 23.04.2013, aprovado pelo Procurador-Chefe Felipe de Araújo Lima, a aplicação de qualquer das sanções previstas no art. 65 da LC 109/2001 provoca a perda de um dos requisitos para compor a administração do Fundo de Pensão, previsto no art. $35, \S 3^{\circ}$, III, da mesma lei. Esse requisito

\footnotetext{
74 Art. 65. A infração de qualquer disposição desta Lei Complementar ou de seu regulamento, para a qual não haja penalidade expressamente cominada, sujeita a pessoa física ou jurídica responsável, conforme o caso e a gravidade da infração, às seguintes penalidades administrativas, observado o disposto em regulamento:

I - advertência;

II - suspensão do exercício de atividades em entidades de previdência complementar pelo prazo de até cento e oitenta dias;

III - inabilitação, pelo prazo de dois a dez anos, para o exercício de cargo ou função em entidades de previdência complementar, sociedades seguradoras, instituições financeiras e no serviço público; e

IV - multa de dois mil reais a um milhão de reais, devendo esses valores, a partir da publicação desta Lei Complementar, ser reajustados de forma a preservar, em caráter permanente, seus valores reais.

$\S 1^{\circ}$ A penalidade prevista no inciso IV será imputada ao agente responsável, respondendo solidariamente a entidade de previdência complementar, assegurado o direito de regresso, e poderá ser aplicada cumulativamente com as constantes dos incisos I, II ou III deste artigo.

$\S 2^{\circ}$ Das decisões do órgão fiscalizador caberá recurso, no prazo de quinze dias, com efeito suspensivo, ao órgão competente.

$\S 3^{\circ} \mathrm{O}$ recurso a que se refere o parágrafo anterior, na hipótese do inciso IV deste artigo, somente será conhecido se for comprovado pelo requerente o pagamento antecipado, em favor do órgão fiscalizador, de trinta por cento do valor da multa aplicada. (Vide Súmula Vinculante $\left.\mathrm{n}^{\circ} 21\right)$

$\S 4^{\circ}$ Em caso de reincidência, a multa será aplicada em dobro.

75 Ofício $\mathrm{n}^{\circ}$ 1878/2013/GAB/DISUP/PREVIC. Disponível em: $<$ http://restrito.serpros.com.br/resenha_limpa/html/Resenha_1190/PREVIC_OF1878_201 3.PDF>. Acesso em 23.05.2016.
} 
é a ausência de penalidade administrativa por infração da legislação da seguridade social ou como servidor público ${ }^{76}$.

Para a PREVIC, a cassação do mandato dos membros da administração por não atender mais ao requisito supracitado não configura um bis in idem, pois não é mais uma sanção, diversa da anterior, mas sim uma consequência da penalidade já sofrida. Nessa linha, segue um valioso trecho do parecer citado:

21. Em linha de desenvolvimento do raciocínio jurídico, vale destacar que a lei complementar não alcançou por bem discriminar que tipo de sanções acarretariam a ilegitimidade para o exercício do mandato. A gradação de sanções nas penalidades de advertência, multa pecuniária, suspensão $e$ inabilitação denota a intenção de apenar segundo a gravidade da conduta objeto de apuração. Ao estabelecer nos requisitos mínimos de acesso e manutenção do cargo/mandato nas instâncias estatutárias da entidade, o diploma legal complementar não especificou quais modalidades de penas administrativas determinam a perda de legitimidade para compor tais órgãos estatutários do Fundo de Pensão. Portanto, qualquer que seja a penalidade aplicada, quer nos parecer que o legislador entendeu ser ela óbice à investidura ou manutenção como membro da alta administração da entidade. Pensar de forma dissonante acarretaria o próprio esvaziamento da norma legal complementar, frustrando assim o legislador e usurpando sua função primordial.

(...)

23. Também merece destaque a evidente distinção entre efeitos da sanção administrativa eventualmente aplicada e a perda dos requisitos de elegibilidade aos órgãos estatutários do Fundo de Pensão. A impossibilidade de ser eleito ou indicado por ausência dos requisitos mínimos atinge a permanência nos conselhos deliberativo e fiscal, bem como na diretoria-executiva dessas entidades e não se confunde com os efeitos de penalidade administrativa, que é mais grave $e$, conforme o caso, impede a atuação do apenado no regime de previdência complementar. (...).

Contudo, o próprio parecer admite que o administrador não ficará eternamente impedido de ser eleito para órgãos estatutários de Fundos de Pensão caso seja condenado em processo administrativo sancionador. O art. 60 do Decreto 4.792/2003, que regulamenta o processo administrativo para

76 Art. 35. As entidades fechadas deverão manter estrutura mínima composta por conselho deliberativo, conselho fiscal e diretoria-executiva.

(...)

$\S 30$ Os membros do conselho deliberativo ou do conselho fiscal deverão atender aos seguintes requisitos mínimos:

(...)

III - não ter sofrido penalidade administrativa por infração da legislação da seguridade social ou como servidor público. 
apuração de responsabilidade no âmbito do regime da previdência complementar, estabelece um prazo máximo de cinco anos para o armazenamento das informações acerca de penalidades extintas ou cumpridas $^{77}$.

O Decreto 4.792/2003 regulamenta o art. 65 da LC 109/2001, introduzido no início do capítulo, trazendo penalidades para condutas específicas em seus art. 63 a 110.

A PREVIC, através da Deliberação n 2, de 17 de maio de 2011, aprovou a Súmula PREVIC no 2, que consagra a aplicação do Princípio da Retroatividade no âmbito da Previdência Complementar Fechada. De acordo com o entendimento da autarquia, se uma pena mais branda for posteriormente prescrita para uma infração no âmbito da previdência complementar, deve ser aplicada às infrações cometidas antes de sua entrada em vigor.

Por exemplo, se um indivíduo fica inabilitado por quatro anos em razão de uma determinada infração e, posteriormente, no momento em que está cumprindo a inabilitação, a penalidade máxima para essa infração é reduzida para uma simples suspensão, ela retroagirá beneficamente para o inabilitado, que terá sua penalidade redefinida ${ }^{78}$.

77 Art. 60. Cinco anos depois de cumprida ou extinta a penalidade, não constará de certidão ou atestado expedido pela Secretaria de Previdência Complementar qualquer notícia ou referência a esta, salvo para a verificação de reincidência.

78 A DIRETORIA COLEGIADA DA SUPERINTENDÊNCIA NACIONAL DE PREVIDÊNCIA COMPLEMENTAR - PREVIC, em sessão realizada em 17 de maio de 2011, com fundamento no artigo $3^{\circ}$, incisos II e VI, da Lei Complementar $n^{\circ} 109$, de 29 de abril de 2011, no artigo $2^{\circ}$, incisos III e V, da Lei $n^{\circ} 12.154$, de 23 de dezembro de 2009, e na Instrução Previc n ${ }^{\circ}$ 5, de 10 de agosto de 2010, decide:

Art. $1^{\circ}$ Aprovar o seguinte enunciado de súmula administrativa, com efeito vinculante no âmbito da Previc e caráter indicativo para as entidades fechadas de previdência complementar:

"Súmula PREVIC no 2. Aplica-se na Previdência Complementar Fechada o princípio da retroatividade da norma mais benéfica, inclusive na hipótese de enquadramento decorrente da alteração promovida pela Resolução CMN n 3.792, de 24.09.2009." 
O processo administrativo para fins de apuração da responsabilidade dos administradores de fundos de pensão em âmbito administrativo está regulamentado pelo Decreto $n^{\circ} 4.942 / 2003$. Ele se inicia com o auto de infração, que é destinado ao registro de ocorrência da infração.

$\mathrm{O}$ art. $4^{\circ}$ do referido decreto prescreve os requisitos para o auto de infração. Quais sejam: o local e data de sua lavratura; a identificação do autuado; a descrição sumária da infração; os fundamentos legais da autuação e das circunstâncias em que foi praticada; a identificação da autoridade autuante com cargo ou função, número de matrícula e assinatura; e o prazo e o local para apresentação da defesa.

O processo administrativo tem questões prejudiciais relevantes como a tempestividade da defesa prévia e do recurso de apelação, a legitimidade das partes, a litispendência e a decadência do poder-dever da PREVIC de autuar comportamentos prescritos, passados cinco anos da prática do ato ${ }^{79}$.

De acordo com o art. $9^{\circ}$ do Decreto $n^{\circ} 4.942 / 2003$, autuado deverá apresentar defesa prévia em até quinze dias a partir da notificação do auto de infração. A defesa prévia indicará: a autoridade a quem é dirigida, a qualificação do autuado, os motivos de fato e de direto que sustentam a defesa e todas as provas que pretende produzir no curso do processo, inclusive o rol de testemunhas.

Ficava a cargo da Secretaria de Previdência Complementar ("SPC") o julgamento dos autos de infração, até que, com o advento do art. 55 da Lei 12.154/2009, foram concedidas à PREVIC as competências daquela secretaria.

\footnotetext{
${ }^{79}$ LEITE, Marcia Lopes. A responsabilidade civil e administrativa dos administradores de fundos de pensão. Disponível em: < http://dspace.idp.edu.br:8080/xmlui/bitstream/handle/123456789/327/Monografia_M\%C 3\%A9rcia\%20Lopes\%20Leite.pdf?sequence=1>. Acesso: 16.05.2016.
} 
O recurso é utilizado para impugnar a decisão da PREVIC, deve ser interposto no prazo de 15 dias, contados da notificação da decisão, e tem efeito suspensivo. Com o advento da Lei 12.154/2009, seu julgamento passou a ser da competência da Câmara de Recursos da Previdência Complementar ("CRPC").

Se a penalidade aplicada for a multa, o recorrente deverá efetuar o depósito de 30\% do valor da multa para que o seu recurso seja conhecido. O depósito de um dos recorrentes não aproveita aos demais.

Para fins da apuração da responsabilidade administrativa dos administradores de fundos de pensão, os incisos I e II do art. 23 do Decreto $n^{\circ}$ 4.942/2009 trazem circunstâncias atenuantes e agravantes.

As circunstâncias atenuantes são: a inexistência de prejuízos para o Fundo de Pensão, ao plano de benefícios por ela administrado ou ao participante - é o caso de, por exemplo, um desenquadramento com relação aos limites quantitativos da Resolução CMN 3.792, desde que ele não tenha nexo de causalidade com algum dano sofrido pelos referidos - e a regularização do ato que ensejou a infração, até a decisão administrativa de primeira instância.

Por sua vez, as circunstâncias agravantes são: a reincidência, o cometimento da infração com o recebimento de vantagens indevidas e a não adoção de providências no sentido de reparar atos lesivos dos quais tenha ciência.

Para cada atenuante, a multa aplicada será reduzida em $20 \%$ do valor inicial e, nas hipóteses de suspensão e inabilitação o período será reduzido em 10\%, observando-se o prazo mínimo de 2 anos.

E, no caso das agravantes, a multa aplicada será aumentada em $20 \%$ do valor inicial - exceto nos casos de reincidência, nos quais esse valor será suplicado - e, nas hipóteses de suspensão e inabilitação o período será 
aumentado em 10\%, observando-se limite de 180 dias para suspensão e dez anos para inabilitação.

A reincidência se verifica quando do cometimento da mesma infração pela mesma pessoa dentro do prazo de cinco anos.

Durante o período de suspensão, os administradores serão privados de suas remunerações e as multas são imputadas aos agentes infratores, podendo a PREVIC exigi-la do Fundo de Pensão solidariamente responsável, resguardado o direito de regresso nesses casos.

A prescrição do processo administrativo tendente a apurar a responsabilidade dos administradores dos fundos de pensão ocorre em: (i) cinco anos, contados da prática da infração; da sua cessação, em caso de infrações permanentes; ou do último dia da prática, em caso de infração continuada; ou (ii) três anos quando, após instaurado o processo administrativo, ele fica paralisado, pendente de despacho ou julgamento.

As circunstâncias que interrompem a prescrição do processo são: a notificação do autuado, os atos inequívocos de apuração e a decisão administrativa recorrível.

O CRPC entende, no Processo $\mathrm{n}^{\circ}$ 44170.000036/2014-11, julgado pela CRPC em 27.01.2016, que é necessária a caracterização do dolo ou culpa para a responsabilização, em âmbito administrativo, por uma aplicação em desacordo com as diretrizes estabelecidas pelo CMN. No referido processo, a PRECE havia negociado títulos públicos sem a observância do preço de referência em plataforma eletrônica. Sendo, a responsabilidade administrativa dos membros da administração dos Fundos de Pensão, de acordo com a jurisprudência do Conselho, subjetiva, assim como a responsabilidade civil.

Também nesse sentido, tem-se o Processo no 44170.000023/2014-41, julgado pela CRPC em 29.07.2015: 
EMENTA: Previdência Complementar. Ausência de recursos tecnológicos na época dos fatos disponíveis para o mercado. Impossibilidade fática de conduta diversa. Proibição de responsabilização objetiva em processo administrativo sancionador. Descabimento de sancionar a conduta pela não subsistência de seus efeitos pedagógicos ao apenado. Inexistência de conduta contumaz. Recurso conhecido e provido pela improcedência do auto de infração.

(Grifou-se)

Além da responsabilidade pelo descumprimento das diretrizes contidas, no art. $4^{\circ}$ da Resolução CMN 3.792, serem subjetivas, necessitam também de elementos objetivos mínimos para sua caracterização. Ou seja, para que alguém seja punido por descumprimento de uma diretriz, não é possível invocá-la genericamente na denúncia. É o entendimento do CRPC no Processo no 44011.000585/2014-18, julgado em 21.01.2016:

EMENTA: Nulidade do Auto de Infração. Ausência de fatos objetivos para caracterizar violação do dever de observar os princípios de segurança, rentabilidade, solvência, liquidez e transparência. Enquadramento legal subjetivo. Tipos abertos devem ter elementos objetivos mínimos em respeito ao princípio constitucional do direito de defesa. Falta de nexo causal e motivação insuficiente para caracterizar a infração. Recurso de Ofício conhecido para manter a decisão da Diretoria Colegiada da PREVIC.

A terceirização da gestão dos ativos não exime os administradores da culpa quando o dirigente "podia e devia controlar o atendimento à Resolução CMN 3.792", nos termos do Processo 45183.000040/2014-01, julgado pelo CRPC em 26.08.2015.

\subsection{Intervenção e liquidação extrajudiciais}

A PREVIC pode decretar a intervenção na administração dos fundos de pensão nos seguintes casos: irregularidade ou insuficiência na constituição das reservas técnicas, provisões e fundos, ou na sua cobertura por ativos garantidores; aplicação dos recursos das reservas técnicas, provisões e fundos de forma inadequada ou em desacordo com as normas expedidas pelos órgãos competentes; situação econômico-financeira insuficiente à preservação da liquidez e solvência de cada um dos planos de benefícios e da entidade no conjunto de suas atividades; situação atuarial desequilibrada; e outras anormalidades definidas em regulamento. 
Essa intervenção tem a duração da aprovação do plano de recuperação pela PREVIC ou da decretação da liquidação do fundo de pensão. Os administradores especiais nomeados pela PREVIC serão remunerados pelo Fundo de Pensão e quaisquer de seus atos que impliquem a oneração ou a disposição do patrimônio dos planos de benefícios dependem de prévia aprovação pela PREVIC.

Como os fundos de pensão não se submetem ao regime de falência, quando não for possível a recuperação dessas entidades, deverá ser decretada a sua liquidação extrajudicial.

Uma das consequências da decretação de intervenção ou liquidação do Fundo de Pensão é a indisponibilidade de seus administradores, com exceção do diretor-fiscal, previsto no art. 43, § 3º, da LC 109/2001. Essa indisponibilidade atinge a todos que tenham exercido estas funções nos últimos 12 meses e pode ser estendida aos bens alienados a qualquer título (não incluídos os bens considerados inalienáveis ou impenhoráveis pela legislação em vigor) pelos administradores condenados a terceiros, desde que haja elementos seguros de convicção.

Não ficarão indisponíveis os bens dos administradores dos Fundos de Pensão caso impeça-os de funcionar por motivos desvinculados de suas atribuições nessas. A PREVIC poderá rever essa disponibilidade a qualquer momento, caso se constate indícios de irregularidade. 


\section{CAPÍTULO 6 - OBRIGAÇÕES DAS EMPRESAS PATROCINADORAS E DAS ENTIDADES ASSOCIATIVAS INSTITUIDORA DOS PLANOS}

\subsection{Obrigações das empresas patrocinadoras}

\subsubsection{Obrigações assumidas perante o Fundo de Pensão}

A empresa que assume, perante seus empregados, obrigação previdenciária autônoma de financiamento ou cofinanciamento de planos de benefícios chama-se patrocinadora.

Nenhuma empresa é obrigada a patrocinar planos de benefícios, porém, uma vez tendo aceitado fazê-lo por ato voluntário, fica obrigado a honrar as obrigações de natureza legal e contratual.

O termo "patrocinador" é fruto de influência do Direito Americano e, apesar de utilizado aqui, não se adequa fielmente à nossa realidade, uma vez que os planos de benefícios aqui no Brasil, via de regra, são copatrocinados: tanto pelos patrocinadores, quanto pelos participantes.

O art. 13 da LC 109/2001 diz que a obrigação do patrocinador ou instituidor com o Fundo de Pensão se dará com relação a cada plano de benefícios.

Convênio de adesão é como é chamado o instrumento pelo qual empresa patrocinadora ou instituidora e Fundo de Pensão acordam seus direitos e obrigações para administração e execução de um plano de benefícios, conforme o art. $61, \S 1^{\circ}$, do Dec. 4.942/2003 e art. 34 da LC 109/2001. Então, para cada plano de benefícios há um convênio de adesão.

Além do convênio de adesão, o regulamento também regrará o plano de benefícios. Este contém normas a respeito do funcionamento do plano, que vinculam não apenas empresa patrocinadora ou instituidora e Fundo de Pensão, mas também os participantes ou assistidos. 
O convênio de adesão dispõe sobre a existência ou não de solidariedade entre patrocinadores dos planos de benefícios, como se depreende do Código Civil, no art. 265, a solidariedade não se presume, mas resulta da lei ou da vontade das partes. O art. 13, §1 ${ }^{\circ}$, da LC 109/2001 traz expressamente a possibilidade de solidariedade entre patrocinadores e instituidores desde que prevista no convênio de adesão.

\subsubsection{Responsabilidade do patrocinador pela resilição do contrato}

Chama-se contrato, de acordo com a ainda atual lição de Orlando Gomes $^{80}$, “o negócio jurídico bilateral, ou plurilateral, que sujeita as partes à observância de conduta idônea à satisfação dos interesses que regularam". O vínculo obrigacional entre patrocinador e Fundo de Pensão, formado por atos de declaração de vontade de ambas as partes e instrumentalizado pelo convênio de adesão, estaria dentro daquela categoria, então.

Como contratos, os convênios de adesão estão sujeitos ao Princípio da Autonomia da Vontade, cujo corolário é que ninguém é obrigado a se manter contratado com outrem. Isso possibilita que o patrocinador, insatisfeito com a administração dos recursos da previdência complementar, resila o convênio de adesão, transferindo a administração daquele plano à outro Fundo de Pensão.

Interessante reiterar que no caso dos fundos de investimento, o art. 66, II, da Instrução CVM n 555 deixa a decisão de substituição do administrador de recursos a cargo da assembleia geral de cotistas, enquanto, no caso dos fundos de pensão, essa decisão competirá ao patrocinador, ainda que não realize contribuições.

A resilição do contrato com o Fundo de Pensão que não apresenta resultados satisfatórios não é apenas uma faculdade do patrocinador, a LC 109/2001 em seu art. 41, § $2^{\circ}$, determina que: “a fiscalização a cargo do

\footnotetext{
${ }^{80}$ GOMES, Orlando. Contratos. Rio de Janeiro: Forense, 1977. P. 17.
} 
Estado não exime os patrocinadores e os instituidores da responsabilidade pela supervisão sistemática das atividades das suas respectivas entidades fechadas".

Essa resilição não significa, de modo algum, qualquer ingerência dos patrocinadores sobre os Fundos de Pensão, suas atividades são independentes e dependes disso para o bom funcionamento da previdência privada.

Se o patrocinador do plano de benefícios for a União, os Estados, o Distrito Federal e os Municípios, suas autarquias, fundações, sociedades de economia mista e outras entidades públicas, o art. 25 da LC 108/2001 prevê ainda a responsabilidade pela falta de fiscalização das atividades dos Fundos de Pensão, quando diz que "as ações exercidas pelo órgão referido no artigo anterior não eximem os patrocinadores da responsabilidade pela supervisão e fiscalização sistemática das atividades das suas respectivas entidades de previdência complementar".

Para Adacir Reis ${ }^{81}$, a previsão do dever de fiscalização no dispositivo agrava as responsabilidades dos administradores de fundos de pensão patrocinados pela União, Estados, Distrito Federal e Municípios, suas autarquias, fundações, sociedades de economia mista e outras entidades públicas.

Porém, ao analisar o dever de diligência de administradores de sociedades anônimas, no Processo Administrativo Sancionador 31/00, julgado em 10 de julho de 2003, com base na decomposição realizada pela doutrina de forma geral - inspirada no duty of care da common law, a CVM trata dever de vigilância e dever de fiscalização como sinônimos.

\footnotetext{
${ }^{81}$ REIS, Adacir. Curso Básico de Previdência Complementar. Editora Revista dos Tribunais: 2012, São Paulo. P. 55.
} 
Luiz Antônio Sampaio Campos ${ }^{82}$ entende que o dever de vigilância “diz respeito, em princípio, não a atos específicos, mas, sim, a uma vigilância geral, no sentido de monitorar o andamento dos negócios e a execução das deliberações e decisões tomadas".

\subsubsection{A aplicação dos deveres fiduciários dos administradores de Fundos de Pensão aos patrocinadores de Fundos de Pensão}

Em toda a relação fiduciária, seja ela qual for, verifica-se a existência de dois elementos, quais sejam: a posição de poder e de gerência atribuída a uma das partes e a da outra parte em que aquela agirá em nome de seus interesses.

A fim de resguardar o instituto da fidúcia, o legislador prescreveu para a administração das sociedades anônimas, uma série de deveres em abstrato: Dever de Diligência, Dever de Lealdade, Dever de Informar e Dever de Obediência.

Tão logo a CVM entendeu que o controle de uma sociedade anônima coloca o seu titular em uma posição de agente fiduciário e, por esse motivo, é necessária a aplicação dos deveres dos administradores também aos controladores.

A Diretora Luciana Dias, no Processo Administrativo Sancionador $n^{\text {o }} 14 / 2009$, afirma que o acionista controlador está sujeito a deveres fiduciários que abrangem tanto aspectos de diligência quanto de lealdade:

52. A Edificadora, na qualidade de acionista controladora da MJ Engenharia, estava sujeita, portanto, a deveres fiduciários que abrangem tanto aspectos de diligência quanto aspectos de lealdade, embora estivesse autorizada a apoiar suas decisões em documentos elaborados por terceiros, assim como os administradores.

Mas o voto da Diretora Norma Parente no Processo Administrativo Sancionador $\mathrm{n}^{\circ}$ 04/99 é que elucida a necessidade de seguir esses padrões

\footnotetext{
${ }^{82}$ CAMPOS, Luiz Antônio Sampaio. Conselho de Administração e Diretoria in Direito das Companhias. Coordenação Alfredo Lamy Filho e José Luiz Bulhões Pedreira. Editora Forense. 2009. P. 1107.
} 
de conduta quando imputa ao controlador responsabilidade pelo descumprimento do art. 156, da Lei 6.404/76:

Faltou ao dever de lealdade, consubstanciado no artigo 156. O controlador não teve qualquer preocupação com o minoritário, tendo agido como se fosse o único dono da companhia. Trata o minoritário como o "intruso" a que se referia Ascarelli.

Consubstanciada essa necessidade, verifica-se que os patrocinadores desfrutam da posição de fiduciários na relação de previdência privada, dependendo os participantes da acertada conduta desses patrocinadores para o resguardo de seus direitos.

Os patrocinadores estão obrigados, dessa maneira, a seguir os padrões de conduta exigidos na atividade de administração dos Fundos de Pensão.

\subsection{Obrigações das entidades associativas instituidoras de planos}

Pessoas jurídicas de caráter profissional, classista ou setorial - ou seja, sindicatos, cooperativas e associações de classe - podem, a partir da LC 109/2001, instituir planos de benefícios para seus membros ou associados, desde que observadas algumas regras.

O objeto social das entidades associativas instituidora dos planos de benefícios se mantém inalterado, não se confundido, portanto, a sua figura com a do Fundo de Pensão com a qual celebrou o convênio de adesão, cada uma permanece com seus objetivos específicos e responsabilidades respectivas.

O órgão regulador exige na Res. CGPC 12/2002 que essas entidades associativas tenham ao menos três anos de existência para que instituam planos de benefícios junto a umo Fundo de Pensão. Além disso, os planos de benefícios instituídos por essas entidades somente poderão ser ofertados na modalidade contribuição definida e os Fundos de Pensão constituídas pelas mesmas deverão terceirizar a gestão dos recursos garantidores das reservas técnicas e provisões, nos termos do art. $31, \S 2^{\circ}$, I, da LC 
109/2001, mediante a contratação de instituição especializada autorizada a funcionar pelo Banco Central ou outro órgão competente.

Como regra, os planos de benefícios instituídos por entidades associativas são financiados integralmente pelos assistidos, mas nada impede que um contrato estabeleça que as contribuições serão efetuadas pelos empregadores dos profissionais associados ou mesmo pelas entidades associativas.

$\mathrm{O}$ instituidor necessita ter, no mínimo, mil associados para criar umo Fundo de Pensão e seu plano de benefícios, pelo menos quinhentos inscritos para que possa entrar em funcionamento, podendo o órgão de supervisão autorizar o funcionamento com número inferior. No caso de o instituidor aderir a um plano de benefícios de Fundo de Pensão em funcionamento, basta ter apenas cinquenta associados.

As entidades associativas têm, assim como as empresas patrocinadoras, a obrigação de supervisionar as atividades do Fundo de Pensão que administra os recursos dos planos de benefícios dos associados. 


\section{CAPÍTULO 7 - Dos limites quantitativos do CMN para aplicações}

\subsection{Introdução}

A Resolução CMN 3.792 regulamenta o art. $9^{\circ}$, § $1^{\circ}$, da LC 109/2001 e traz limites à atuação do gestor dos ativos dos planos de benefícios. Esses limites são de ordem prudencial e quantitativa. Esse capítulo se destina à análise dos limites quantitativos impostos por ela.

Importa dizer que não há limites mínimos para aplicação em cada um desses investimentos e é vedado ao CMN impô-los por força do art. $9^{\circ}$, $\S 2^{\circ}$, da Resolução CMN 3.792.

Normalmente, esses recursos vêm de uma dotação inicial da entidade patrocinadora - por exemplo, no caso da Petros ${ }^{83}$, o Regulamento de janeiro de 2006 revela que houve um aporte inicial de dezoito milhões de cruzeiros da Petrobrás - mais os recursos das contribuições de patrocinadores e participantes e os seus rendimentos.

\subsection{Dos limites de alocação por investimento}

\subsubsection{Renda fixa}

Os limites de alocação variam quanto ao segmento que o investimento no qual se aplica o recurso se insere. No caso dos investimentos de renda fixa, que são os investimentos que geram um retorno pré-definido, não dependendo do resultado da empresa investida, pode-se promover a aplicação da integralidade dos recursos, observados os seguintes sublimites:

\footnotetext{
83 Regulamento da PETROS. Disponível em: <https://www.petros.com.br/petrossite/Download/regulamentos/Regulamento\%20Plano\% 20Petros_jan2006.pdf>. Acesso em 26.05.2016.
} 


\begin{tabular}{|c|c|c|}
\hline $\begin{array}{l}\text { Porcentagem } \\
\text { dos recursos } \\
\text { do plano }\end{array}$ & Ativos & Exceção \\
\hline & $\begin{array}{c}\text { Títulos da dívida pública mobiliária } \\
\text { federal }\end{array}$ & \\
\hline $100 \%$ & $\begin{array}{l}\text { Cotas de fundos de investimento } \\
\text { admitidas à negociação no mercado } \\
\text { secundário por intermédio de bolsa de } \\
\text { valores, na forma regulamentada pela } \\
\text { CVM, cujas carteiras visem refletir as } \\
\text { variações e rentabilidade de índice de } \\
\text { referência de renda fixa composto } \\
\text { exclusivamente por títulos da dívida } \\
\text { pública mobiliária federal interna }\end{array}$ & \\
\hline $80 \%$ & $\begin{array}{l}\text { Ativos classificados no segmento de } \\
\text { renda fixa }\end{array}$ & $\begin{array}{c}\text { Ativos inseridos } \\
\text { dentro dos limites } \\
\text { de } 100 \% \text { e } 20 \%\end{array}$ \\
\hline \multirow{6}{*}{$20 \%$} & $\begin{array}{l}\text { Cédulas de crédito bancário (CCB), } \\
\text { certificados de cédulas de crédito } \\
\text { bancário (CCCB) e notas promissórias }\end{array}$ & \\
\hline & $\begin{array}{l}\text { Notas de crédito à exportação (NCE) e } \\
\text { cédulas de crédito à exportação (CCE) }\end{array}$ & \\
\hline & $\begin{array}{l}\text { Cotas de fundos de investimento em } \\
\text { direitos creditórios (FIDC) e cotas de } \\
\text { fundos de investimento em cotas de } \\
\text { fundos de investimento em direitos } \\
\text { creditórios (FICFIDC) }\end{array}$ & \\
\hline & $\begin{array}{l}\text { Certificados de recebíveis imobiliários } \\
\text { (CRI) }\end{array}$ & \\
\hline & Cédulas de crédito imobiliário (CCI) & \\
\hline & $\begin{array}{l}\text { Cédulas de produto rural (CPR), } \\
\text { certificados de direitos creditórios do } \\
\text { agronegócio (CDCA), certificados de } \\
\text { recebíveis do agronegócio (CRA) e } \\
\text { warrant agropecuário (WA) }\end{array}$ & \\
\hline
\end{tabular}




\subsubsection{Renda variável}

Quanto aos investimentos classificados no segmento de renda variável, cujo retorno dependerá do resultado do investimento, o limite é de 70\%, observados os sublimites:

\begin{tabular}{|c|c|c|}
\hline $\begin{array}{l}\text { Porcentagem } \\
\text { dos recursos } \\
\text { do plano }\end{array}$ & Ativos & Exceção \\
\hline $70 \%$ & $\begin{array}{c}\text { Ações de emissão de companhias } \\
\text { abertas admitidas à negociação no } \\
\text { segmento Novo Mercado da } \\
\text { BM\&FBovespa }\end{array}$ & \\
\hline $60 \%$ & $\begin{array}{l}\text { Ações de emissão de companhias } \\
\text { abertas admitidas à negociação no } \\
\text { segmento Nível } 2 \text { da BM\&FBovespa }\end{array}$ & \\
\hline $50 \%$ & $\begin{array}{c}\text { Ações de emissão de companhias } \\
\text { abertas admitidas à negociação no } \\
\text { segmento Bovespa Mais da } \\
\text { BM\&FBovespa }\end{array}$ & \\
\hline $40 \%$ & $\begin{array}{l}\text { Ações de emissão de companhias } \\
\text { abertas admitidas à negociação no } \\
\text { segmento Nível } 1 \text { da BM\&FBovespa }\end{array}$ & \\
\hline $35 \%$ & $\begin{array}{c}\text { Ações de emissão de companhias } \\
\text { abertas não mencionadas nos itens e } \\
\text { cotas de fundos de índice referenciados } \\
\text { em ações admitidas à negociação em } \\
\text { bolsa de valores }\end{array}$ & $\begin{array}{l}\text { Ações } \\
\text { mencionadas nas } \\
\text { linhas anteriores }\end{array}$ \\
\hline $20 \%$ & Valores mobiliários de emissão de SPE & $\begin{array}{c}\text { Devem ser } \\
\text { computados aqui } \\
\text { valores prestados } \\
\text { em garantia pelo } \\
\text { Fundo de Pensão } \\
\text { em obrigações } \\
\text { contraídas por SPE } \\
\text { na qual tenha } \\
\text { participação }\end{array}$ \\
\hline
\end{tabular}




\begin{tabular}{|c|c|c|}
\hline $\mathbf{3 \%}$ & Demais investimentos & \\
\hline
\end{tabular}

\subsubsection{Estruturados}

No que concerne aos investimentos classificados como estruturados, que são aqueles realizados ad hoc, ou seja, o próprio Fundo de Pensão define suas regras para aplicação, o limite é de $20 \%$ e os sublimites são os seguintes:

\begin{tabular}{|c|c|c|}
\hline $\begin{array}{c}\text { Porcentagem } \\
\text { dos recursos } \\
\text { do plano }\end{array}$ & Ativos & Exceção \\
\hline \multirow{2}{*}{$\mathbf{1 0 \%}$} & Cotas de fundos de investimento imobiliário & \\
\cline { 2 - 3 } & $\begin{array}{l}\text { Cotas de fundos de investimento e em cotas de } \\
\text { fundos de investimento em cotas de fundos de } \\
\text { investimento classificados como multimercado }\end{array}$ & \\
\hline
\end{tabular}

\subsubsection{Outros tipos de investimento}

A Resolução CMN 3.792 contém mais alguns limites de alocação por investimento. Para operações com participantes, o limite a ser observado é de $15 \%$ os recursos do plano. O limite para aplicação de recursos em investimentos no exterior é de $10 \%$ e, por último, o limite para aplicação no segmento de imóveis é de $8 \%$. Dessa forma, pode-se simplificar esses limites com a tabela abaixo:

\begin{tabular}{|c|c|c|}
\hline $\begin{array}{c}\text { Porcentagem } \\
\text { dos recursos } \\
\text { do plano }\end{array}$ & Tipo de investimento & Exceção \\
\hline $\mathbf{1 0 0 \%}$ & Renda fixa & \\
\hline $\mathbf{7 0 \%}$ & Renda variável & \\
\hline $\mathbf{2 0 \%}$ & Investimentos estruturados & \\
\hline $\mathbf{1 5 \%}$ & Operações com participantes & \\
\hline
\end{tabular}




\begin{tabular}{|c|c|c|}
\hline $\mathbf{1 0 \%}$ & Investimentos no exterior & \\
\hline $\mathbf{8 \%}$ & Investimentos com imóveis & \\
\hline
\end{tabular}

\subsection{Dos limites de alocação por emissor}

Os limites de alocação por emissor dizem respeito à porcentagem do total de ativos do plano de benefícios que pode ser aplicada em títulos emitidos por uma entidade. Essa porcentagem vai variar de acordo com a entidade emissora.

Para efeito desses limites, serão considerados como único emissor os integrantes de um mesmo grupo econômico ou financeiro, bem como as companhias controladas pelo tesouro estadual ou municipal.

Os ativos recebidos como lastro de operações compromissadas também devem ser computados nesses limites.

Para a verificação dos limites será desconsiderada a participação em empresas constituídas exclusivamente com o objetivo de participar, direta ou indiretamente, do capital de companhias abertas. Serão observados os investimentos finais do plano de benefícios.

O quadro abaixo simplifica cada um desses limites:

\begin{tabular}{|c|c|c|}
\hline $\begin{array}{c}\text { Porcentagem } \\
\text { dos recursos } \\
\text { do plano }\end{array}$ & Emissor & Exceção \\
\hline $\mathbf{1 0 0 \%}$ & Tesouro Nacional & \\
\hline \multirow{2}{*}{$\mathbf{2 0 \%}$} & $\begin{array}{c}\text { Instituição financeira autorizada pelo } \\
\text { Bacen }\end{array}$ & \\
\cline { 2 - 3 } & $\begin{array}{c}\text { Depósitos em poupança e coobigações } \\
\text { de responsabilidade da instituição } \\
\text { financeira }\end{array}$ & \\
\hline
\end{tabular}




\begin{tabular}{|c|c|c|}
\hline & $\begin{array}{c}\text { Fundos de investimento com cotas } \\
\text { admitidas à negociação no mercado } \\
\text { secundário por intermédio de bolsa de } \\
\text { valores, cujas carteiras visem refletir } \\
\text { índice de referência de renda fixa } \\
\text { composto exclusivamente por títulos } \\
\text { da dívida pública mobiliária federal } \\
\text { interna }\end{array}$ & \\
\hline $15 \%$ & $\begin{array}{l}\text { Debêntures de infraestrutura emitidas } \\
\text { na forma disposta no art. } 2^{\circ} \text { da Lei n } \\
12.431 \text {, de } 24 \text { de junho de } 2011 \text {, por } \\
\text { sociedade por ações, aberta ou } \\
\text { fechada, cuja oferta pública tenha sido } \\
\text { registrada na CVM, ou que tenha sido } \\
\text { objeto de dispensa, e que possuam } \\
\text { garantia de títulos públicos federais } \\
\text { que representem pelo menos trinta por } \\
\text { cento do principal na data de } \\
\text { vencimento dos compromissos } \\
\text { estipulados na escritura de emissão, } \\
\text { observadas as normas da CVM }\end{array}$ & $\begin{array}{c}\text { Deve ser } \\
\text { computado nesse } \\
\text { limite os valores } \\
\text { dados pelo Fundo } \\
\text { de Pensão a título } \\
\text { de garantia em } \\
\text { obrigações } \\
\text { contraídas por SPE } \\
\text { na qual tenha } \\
\text { participação. }\end{array}$ \\
\hline \multirow{7}{*}{$10 \%$} & Tesouro estadual ou municipal & \\
\hline & $\begin{array}{c}\text { Companhia aberta com registro na } \\
\text { CVM ou assemelhada }\end{array}$ & \\
\hline & Organismo multilateral & \\
\hline & Companhia securitizadora & $\begin{array}{c}\text { Nesse caso, } \\
\text { considera-se } \\
\text { como emissor cada } \\
\text { patrimônio } \\
\text { separado } \\
\text { constituído com a } \\
\text { adoção do referido } \\
\text { regime }\end{array}$ \\
\hline & Patrocinador do plano de benefícios & \\
\hline & $\begin{array}{l}\text { Fundo de investimento em direitos } \\
\text { creditórios ou fundo de investimento } \\
\text { em cotas de fundo de investimento em } \\
\text { direitos creditórios }\end{array}$ & \\
\hline & Fundo de índice referenciado em cesta & \\
\hline
\end{tabular}




\begin{tabular}{|c|c|c|}
\hline & de ações de companhias abertas & \\
\hline & $\begin{array}{l}\text { SPE, caso não contemplado nas } \\
\text { debêntures de infraestrutura } \\
\text { supracitadas. }\end{array}$ & $\begin{array}{c}\text { Deve ser } \\
\text { computado nesse } \\
\text { limite os valores } \\
\text { dados pelo Fundo } \\
\text { de Pensão a título } \\
\text { de garantia em } \\
\text { obrigações } \\
\text { contraídas por SPE } \\
\text { na qual tenha } \\
\text { participação. } \\
\text { Sendo limitado, } \\
\text { nesse caso, o valor } \\
\text { à participação } \\
\text { direta ou indireta } \\
\text { da EPFC no capital } \\
\text { da SPE. }\end{array}$ \\
\hline & $\begin{array}{l}\text { Fundo de investimento; ou fundo de } \\
\text { investimento em cotas de fundo de } \\
\text { investimento classificado no segmento } \\
\text { de investimentos estruturados; ou } \\
\text { fundo de investimento em cota de } \\
\text { fundo de investimento classificado } \\
\text { como dívida externa no segmento } \\
\text { investimentos no exterior. }\end{array}$ & \\
\hline & $\begin{array}{l}\text { Fundos de investimento cujas cotas } \\
\text { sejam admitidas à negociação no } \\
\text { mercado secundário por intermédio de } \\
\text { bolsa de valores, cujas carteiras visem } \\
\text { refletir as variaçôes e rentabilidade de } \\
\text { índice de referência de renda fixa. }\end{array}$ & \\
\hline $5 \%$ & Demais casos & \\
\hline
\end{tabular}




\subsection{Limites de concentração por emissor}

Quanto à concentração de ativos por emissor, os limites estabelecidos pela Resolução CMN 3.792 são os seguintes:

\begin{tabular}{|c|c|c|}
\hline $\begin{array}{l}\text { Porcentagem } \\
\text { dos recursos } \\
\text { do plano }\end{array}$ & Concentração & Exceção \\
\hline \multirow{3}{*}{$25 \%$} & $\begin{array}{l}\text { Capital total de uma mesma companhia } \\
\text { aberta ou SPE }\end{array}$ & $\begin{array}{c}\text { Devem ser } \\
\text { considerados } \\
\text { adicionalmente os } \\
\text { bônus de } \\
\text { subscrição, os } \\
\text { recibos de } \\
\text { subscrição e as } \\
\text { debêntures } \\
\text { conversíveis em } \\
\text { ações de uma } \\
\text { mesma companhia }\end{array}$ \\
\hline & $\begin{array}{l}\text { Capital votante de uma mesma } \\
\text { companhia aberta }\end{array}$ & $\begin{array}{c}\text { devem ser } \\
\text { considerados } \\
\text { adicionalmente os } \\
\text { bônus de } \\
\text { subscrição, os } \\
\text { recibos de } \\
\text { subscrição e as } \\
\text { debêntures } \\
\text { conversíveis em } \\
\text { ações de uma } \\
\text { mesma companhia }\end{array}$ \\
\hline & $\begin{array}{l}\text { Patrimônio líquido de uma mesma } \\
\text { instituição financeira autorizada a } \\
\text { funcionar pelo Bacen }\end{array}$ & \\
\hline
\end{tabular}




\begin{tabular}{|c|c|}
\hline $\begin{array}{c}\text { Patrimônio líquido de um mesmo: } \\
\text { fundo de índice referenciado em cesta } \\
\text { de ações de companhias abertas; fundo } \\
\text { de investimento classificado no } \\
\text { segmento de investimentos } \\
\text { estruturados; fundo de investimento } \\
\text { constituído no Brasil que tenha em sua } \\
\text { carteira ativos } \\
\text { classificados no segmento de } \\
\text { investimentos no exterior; fundo de } \\
\text { índice do exterior admitido à } \\
\text { negociação em bolsa de valores do } \\
\text { Brasil; fundo de investimento ou fundo } \\
\text { de investimento em cota de fundo de } \\
\text { investimento classificado como dívida } \\
\text { externa no segmento investimentos no } \\
\text { exterior; fundos de investimento cujas } \\
\text { cotas sejam admitidas à negociação no } \\
\text { mercado } \\
\text { secundário por intermédio de bolsa de } \\
\text { valores, na forma regulamentada pela } \\
\text { CVM, cujas } \\
\text { carteiras visem refletir as variações e } \\
\text { rentabilidade de índice de referência de } \\
\text { renda fixa. }\end{array}$ & $\begin{array}{l}\text { Os limites de } \\
\text { aplicação para } \\
\text { fundos de } \\
\text { investimento } \\
\text { classificado no } \\
\text { segmento de } \\
\text { investimentos } \\
\text { estruturados não se } \\
\text { aplicam a fundos } \\
\text { de investimento em } \\
\text { cotas de fundo de } \\
\text { investimento desde } \\
\text { que suas aplicações } \\
\text { observem tais } \\
\text { limites e nem para } \\
\text { a fundos de } \\
\text { investimento } \\
\text { imobiliário que } \\
\text { possuam em sua } \\
\text { carteira } \\
\text { exclusivamente } \\
\text { imóveis concluídos } \\
\text { e com } \\
\text { certidão de habite- } \\
\text { se. }\end{array}$ \\
\hline $\begin{array}{l}\text { Patrimônio separado constituído nas } \\
\text { emissões de certificado de recebíveis } \\
\text { com a adoção de regime fiduciário }\end{array}$ & \\
\hline
\end{tabular}

Esses limites não são aplicáveis para as "debêntures de infraestrutura emitidas na forma disposta no art. $2^{\circ}$ da Lei ${ }^{\circ} 12.431$, de 24 de junho de 2011, por sociedade por ações, aberta ou fechada, cuja oferta pública tenha sido registrada na CVM, ou que tenha sido objeto de dispensa, e que possuam garantia de títulos públicos federais que representem pelo menos trinta por cento do principal na data de vencimento dos compromissos estipulados na escritura de emissão, observadas as normas da CVM".

No caso de fundo de índice referenciado em cesta de ações de companhias abertas; fundo de investimento classificado no segmento de 
investimentos estruturados; fundo de investimento constituído no Brasil que tenha em sua carteira ativos classificados no segmento de investimentos no exterior e fundo de índice do exterior admitido à negociação em bolsa de valores do Brasil; fundo de investimento ou fundo de investimento em cota de fundo de investimento classificado como dívida externa no segmento investimentos no exterior; fundos de investimento cujas cotas sejam admitidas à negociação no mercado secundário por intermédio de bolsa de valores, na forma regulamentada pela CVM, cujas carteiras visem refletir as variações e rentabilidade de índice de referência de renda fixa, o Fundo de Pensão tem 60 dias, a partir da data de cada integralização para enquadrarse nos limites previstos.

O limite estabelecido para aplicação em uma mesma SPE pode ser aumentado para $30 \%$ quando essas forem constituída exclusivamente para atuar como concessionária, permissionária, arrendatária ou autorizatária.

Jean Luiz Souza Vasquez ${ }^{84}$, em sua dissertação de mestrado, atesta que a SPE não é um tipo societário novo, sua diferença reside tão somente no objeto social que definido em seu estatuto:

A sociedade de propósito específico ou "SPE" não constitui um novo tipo societário além daqueles já previstos na legislação brasileira. A SPE pode ser uma sociedade simples, em nome coletivo, comandita simples, limitada, sociedade anônima ou comandita por ações. $O$ que a faz ser diferente é o seu objeto social voltado para uma atividade específica.

Ela é denominada de SPE por segregar recursos específicos de seus sócios, sendo certo que ela não será utilizada para celebrar qualquer outro negócio jurídico que não seja aquele para qual foi criada. Esse aspecto acarreta inúmeras vantagens para seus controladores e para aqueles que se relacionam com a SPE, como credores e a própria administração pública.

Nessa análise, a Resolução CMN 3.792 ordena que se observe os investimentos finais do Fundo de Pensão, desconsiderando-se as

${ }^{84}$ VASQUEZ, Jean Luiz Souza. A Sociedade de Propósito Específico na Parceria Público- Privada: Uma Análise de Direito Societário. Disponível em: 〈http://www.dominiopublico.gov.br/download/teste/arqs/cp119788.pdf >. Acesso em: 29.05.2016. 
participações em empresas constituídas exclusivamente com o objetivo de participar, direta ou indiretamente, do capital de companhias abertas.

\subsection{Dos limites de concentração por investimento}

A Resolução CMN 3.792 estabelece também limitações para a concentração desses recursos em um mesmo investimento. Elas podem ser definidas na seguinte tabela:

\begin{tabular}{|c|c|c|}
\hline $\begin{array}{l}\text { Porcentagem } \\
\text { dos recursos } \\
\text { do plano }\end{array}$ & Concentração & Exceção \\
\hline $25 \%$ & $\begin{array}{c}\text { Uma mesma série de títulos ou valores } \\
\text { mobiliários }\end{array}$ & $\begin{array}{c}\text { Bônus de } \\
\text { subscrição de } \\
\text { ações, recibos de } \\
\text { subscrição de } \\
\text { ações, certificados } \\
\text { de recebíveis } \\
\text { emitidos com } \\
\text { adoção de regime } \\
\text { fiduciário e } \\
\text { debêntures de } \\
\text { infraestrutura (art. } \\
2^{\circ} \text { da Lei no } \\
12.431) .\end{array}$ \\
\hline $25 \%$ & $\begin{array}{l}\text { Uma mesma classe ou série de cotas de } \\
\text { fundos de investimento em direitos } \\
\text { creditórios }\end{array}$ & \\
\hline $25 \%$ & $\begin{array}{l}\text { Um mesmo empreendimento } \\
\text { imobiliário }\end{array}$ & \\
\hline
\end{tabular}

\subsection{Desenquadramento passivo}

Para fins da Resolução CMN 3.792, os desenquadramentos passivos decorrentes de: valorização de ativos; recebimento de ações em 
bonificação; conversão de bônus ou recibo de subscrição; exercício do direito de preferência; reestruturação societária na qual o fundo de pensão não efetue novos aportes; recebimentos de ativos provenientes de empréstimos realizados e reavaliação de imóveis não constituem infração desde que corrigidos no prazo de 720 dias, que serão suspensos enquanto o montante financeiro desenquadrado for inferior ao superávit acumulado do respectivo plano de benefícios.

O Fundo de Pensão fica impedido, enquanto desenquadrada de realizar operações que agravem essa situação.

O parágrafo único do art. 24 da Resolução CMN 3.792 estabelece que para fins da análise dos limites de aplicação, os ativos emprestados devem ser considerados, portanto o art. 52, VI, da referida resolução, que diz que o recebimento de ativos provenientes de operações de empréstimo não configura infração quando eliminado em 720 dias, não está se referindo a ativo que ele emprestou, mas, possivelmente, a ativos recebidos em razão dessas operações.

\subsection{Vedações aos Fundos de Pensão}

A Resolução CMN 3.792 estabelece uma série de condutas que são proibidas aos fundos de pensão em seu art. 53.

É vedado aos Fundos de Pensão realizar operações de compra e venda, ou qualquer outra forma de troca de ativos entre planos que estejam sob a sua administração. Também não pode ela realizar operações de crédito com suas patrocinadoras, ou mesmo atuar como instituição financeira - salvo nos casos previstos pela resolução in comento - ou prestar fiança, aval, aceite ou coobrigar-se de qualquer forma, salvo com relação à SPE que participe desde $1^{\circ}$ de janeiro de 2010.

O CMN não permite a aplicação de recursos em ativos ou modalidades não previstas na sua resolução. Também veda a aplicação de 
recursos em títulos ou valores mobiliários de companhias sem registro na CVM - ressalvados os casos expressamente previstos nesta Resolução - e em companhias que não estejam admitidas à negociação nos segmentos Novo Mercado, Nível 2 ou Bovespa Mais da BM\&FBovespa, com exceção às que tiverem realizado sua primeira distribuição pública em data anterior a 29 de maio de 2001.

Não pode o Fundo de Pensão realizar operações com ações fora de bolsa de valores ou mercado de balcão organizado por entidade autorizada a funcionar pela CVM, exceto na distribuição pública de ações; no exercício do direito de preferência; na conversão de debêntures em ações; no exercício de bônus ou de recibos de subscrição; no casos previstos em regulamentação estabelecida pela SPC (atualmente pela PREVIC); e em demais casos expressamente previstos nesta Resolução.

Também é vedado que os Fundos de Pensão mantenham posições em mercados derivativos, diretamente ou por meio de fundo de investimento a descoberto; ou que gerem possibilidade de perda superior ao valor do patrimônio da carteira ou do fundo de investimento; devido ao alto risco contido nesse tipo de investimento.

Os fundos de pensão são proibidos de realizar operações day trade, com exceção às realizadas em plataforma eletrônica ou em bolsa de valores ou de mercadorias e futuros, desde que devidamente justificadas em relatório atestado pelo AETQ ou pelo administrador do fundo de investimento. Não podem atuar como incorporador, de forma direta, indireta ou por meio de fundo de investimento imobiliário; não pode adquirir ou manter terrenos, exceto aqueles destinados à realização de empreendimentos imobiliários ou construção de imóveis para aluguel, renda ou uso próprio, e desde que haja previsão na política de investimentos do plano de benefícios. 
Como regra, também não é permitida a aplicação de recursos no exterior por meio de carteira própria ou administrada.

Essas vedações aplicam-se tanto à carteira própria quanto à administrada, fundos de investimento e fundos de investimento em cotas de fundo de investimento; excetuando-se: os fundos de investimento e fundos de investimento em cotas de fundos de investimento classificados como dívida externa; os fundos de investimento em direitos creditórios e fundos de investimento em cotas de fundos de investimento em direitos creditórios; os fundos de investimento e fundos de investimentos em cotas de fundos de investimento em participações; e os fundos de investimento em empresas emergentes.

Os fundos de investimento imobiliário podem aplicar em modalidades não previstas na Resolução. Podem também aplicar em companhias sem registro na CVM e que não façam parte dos segmentos especiais de listagem.

Para os fundos de investimento e fundos de investimento em cotas de fundos de investimento classificados como multimercado, é permitida a aplicação em companhias não listadas em segmento especial; a aplicação em derivativos a descoberto ou com possibilidade de perda superior ao patrimônio do plano; a realização de operações day trade e a aplicação de recursos no exterior por meio de carteira própria ou administrada. 


\section{CAPÍTULO 8 - LIMITES AO PODER REGULAMENTAR}

\subsection{A questão da sanção penal por descumprimento da Resolução CMN no 3.792}

\subsubsection{A imprecisão do tipo penal de gestão temerária}

O parágrafo único do art. $4^{\circ}$ da Lei 7.492/1986 trouxe um tipo penal, considerado por muitos inconstitucional ${ }^{85}$, trata-se do crime de gestão temerária, que tem a seguinte redação, muito sucinta e pouco elucidativa:

Art. $4^{\circ}$ Gerir fraudulentamente instituição financeira:

Pena - Reclusão, de 3 (três) a 12 (doze) anos, e multa.

Parágrafo único. Se a gestão é temerária:

Pena - Reclusão, de 2 (dois) a 8 (oito) anos, e multa.

É com relação a esse tipo penal extremamente vago e impreciso que Cezar Roberto Bittencourt ${ }^{86}$ escreve as seguintes linhas:

A definição da conduta incriminada no parágrafo único do dispositivo examinado - fazendo um trocadilho - é uma grande temeridade, na medida em que coloca em risco todos os postulados libertatórios assegurados em um Estado Democrático de Direito, devidamente recepcionados pela atual Constituição Federal, dentre os quais, destacadamente, encontra-se o princípio da reserva legal, cunhado por Feurbach, no início do século XIX, sob o verbete nullun crimen nulla poena sine lege.

De fato, o referido crime inibiu a atividade dos gestores, tanto que Gamil Föppel El Hireche e Gabriel Dalla Favera de Oliveira ${ }^{87}$ chegam e asseverar que não há nenhuma baliza para realizar a subsunção de fato à

${ }^{85}$ Nesse sentido, tem-se o trabalho de Polianna Pereira dos Santos disponível em: $<$ http://revistapensamentojuridico.fadisp.com.br/ojs/index.php/pensamentojuridico/article /download/21/37> Acesso em 22.05.2016

86 BITENCOURT, Cezar Roberto; BREDA, Juliano. Crimes Contra o Sistema Financeiro Nacional \& Contra o Mercado de Capitais. Rio de Janeiro: Lumen Juris, 2011. P. 54.

${ }^{87}$ HIRECHE, Gamil Föppel El, e OLIVEIRA, Gabriel Dalla Favera de. Notas críticas acerca da tipicidade nos delitos penais econômicos: o viés concreto de análise sobre delito de gestão temerária, previsto no art. $4^{o}$, parágrafo único, da Lei $n^{o}$ 7.492/76. Disponível

em: <https://d24kgseos9bn1o.cloudfront.net/editorajuspodivm/arquivos/paginas_265_297.pdf $>$ Acesso em: 30.05.2016. 
norma nesse caso, já que a própria noção de temeridade se confunde com a de imprudência ${ }^{88}$.

Não há qualquer elemento que sirva de limite ou baliza para a atividade de subsunção de determinado fato a esta norma, note-se que a própria expressão "temerária" confunde-se com noções de culpa em sentido estrito - imprudência, imperícia e negligência. Qual seria, então, a diferença ôntica, por exemplo, entre uma gestão "temerária" e uma gestão "imprudente"? Parece não haver. Cumpre ressaltar que, a despeito de se confundirem as noções em diversas denúncias e julgados, não há previsão legal de modalidade culposa no presente delito.

\subsubsection{A busca por parâmetros}

Essa característica do tipo penal in comento fez com que a doutrina buscasse parâmetros em normas que regulam a atividade de gestão promovida por instituições financeiras (nos termos do art. $1^{\circ}$ da Lei 7.492/1986).

Leonardo Henrique Mundim Moraes Oliveira ${ }^{89}$, por exemplo, entende que o descumprimento de qualquer norma editada pela $\mathrm{CMN}$ ou

${ }^{88}$ Nesse sentido, a seguinte decisão: PENAL E PROCESSUAL PENAL. CRIMES CONTRA O SISTEMA FINANCEIRO. LEI N ${ }^{\circ}$ 7.492/86, ART. $4^{\circ}$ E ART. $5^{\circ}$. GESTÃO TEMERÁRIA E DESVIO DE RECURSO EM PROVEITO PRÓPRIO E ALHEIO. COMPETENNCIA DA JUSTIÇA FEDERAL. ART. 26 DA LEI N 7.432/86 E ART. 109-VI DA CONSTITUIÇÃO FEDERAL. RECURSO EM SENTIDO ESTRITO PROVIDO. 1. A conduta tipificada como o crime de gestão temerária e de desvio de dinheiro, descrita nos arts. $4^{o}$ e $5^{\circ}$ da Lei $n^{o} 7.492 / 86$, consiste em administrar uma instituição financeira sem a cautela inerente a tal atividade, o que coloca em risco o bom desenvolvimento da empresa ou dos recursos postos a seus cuidados, em desatenção à prudência exigida de quem administra dinheiro ou fundos de outrem. 2. A Lei n. 7.492/86 equipara a instituição financeira a pessoa jurídica que capta ou administra seguros, câmbio, consórcio, capitalização ou qualquer tipo de poupança, ou recursos de terceiros. 3. É da competência da Justiça Federal processar e julgar crime financeiro de operações de consórcio clandestino, ou seja, sem autorização legal (STJ, CC n. 41.357/SP - $3^{a}$ Seção Relator Ministro José Arnaldo da Fonseca). 4. Caracterizada a atividade de instituição financeira pela AFAP-Agência de Fomento do Amapá (Banco do Povo) e, desviados recursos de um dos fundos dos quais era responsável, o FDA - Fundo de Desenvolvimento do Artesanato, pelo então Diretor - Presidente da AFAP (Banco do Povo) em seu proveito próprio e alheio resta, em tese, demonstrada a prática da conduta de gestão temerária e desvio de recursos de instituição financeira, delitos de competência da Justiça Federal. 5. Recurso em sentido estrito provido.

(Grifou-se)

TRF-1 - RSE: 6371 AP 0006371-75.2010.4.01.3100, Relator: DESEMBARGADOR FEDERAL I'TALO FIORAVANTI SABO MENDES, Data de Julgamento: 26/03/2013, QUARTA TURMA, Data de Publicação: e-DJF1 p.315 de 19/04/2013. 
pelo Banco Central do Brasil ensejaria a tipicidade da conduta, pois, se as normas representam um fator de cautela e o administrador não a obedece, ele está agindo de forma temerária:

Essa a razão das Resoluções do Conselho Monetário Nacional (CMN) e Circulares do Banco Central do Brasil que estabelecem princípios e limites ao empenho de pecúnia, como a seletividade de investimentos, a diversificação dos riscos, a multiplicidade de clientes e a obrigatoriedade de respeito a garantias $e$ requisitos básicos nas operações de abertura de crédito pré-aprovado e nos financiamentos. Referidos postulados zelam por um fator de cautela imposto após estudos abstratos acerca do nível mínimo de segurança, necessário, em tese, à perenidade e à credibilidade das Instituições Financeiras nacionais e, conseqüentemente, de todo o Sistema Financeiro Nacional.

Isso significa que não se pode punir por gestão temerária, por exemplo, os administradores de um banco que sofrera perdas irreversíveis por causa de um investimento de alto risco, desde que a intenção fosse apenas angariar lucros na operação, e não tripudiar com o dinheiro alheio. A situação se inverte, todavia, caso fique comprovada a inobservância aos requisitos básicos suprareferidos, hipótese na qual se aceitara, implícita e temerariamente, que o fracasso da empreitada levasse à dangerosa situação de insolvência.

\subsubsection{Conceito de temeridade}

Sun Tzu explica em que há cinco fraquezas de caráter que podem afetar um comandante e a primeira delas é a temeridade. Para ele, temeridade é uma ousadia despropositada, que demonstra uma avaliação equivocada. Tu Um complementa: "um comandante ousado, mas pouco inteligente, é uma verdadeira calamidade”.

Logo em seguida, Sun Tzu expõe a segunda fraqueza de caráter, que Wang Hsi atribui àquele que "rapidamente foge ao se deparar com o perigo", a pusilanimidade.

Ou seja, ousadia e temeridade não são palavras que se confundem, os administradores podem assumir riscos, que podem ser até superiores aos que os participantes concordaram, e de forma inteligente.

${ }^{89}$ OLIVEIRA, Leonardo Henrique Mudim Moraes. Crimes de gestão fraudulenta e gestão temerária em Instituição Financeira. Disponível em: <http://www2.senado.leg.br/bdsf/bitstream/handle/id/502/r143-05.PDF?sequence=4> Acesso 22.05.2016. 
A Resolução CMN 3.792 estabelece dois tipos de controle: um relacionado aos limites para aplicação e outro relacionado à prudência do administrador, previsto nas regras dos arts. $9^{\circ}$ ao 13 . Os dois controles não se confundem e podem até ser conflitantes de acordo com o caso concreto. Adacir Reis ${ }^{90}$, por exemplo, demonstra situações nas quais a observância de limites pode causar dano ao patrimônio dos planos de benefícios:

\begin{abstract}
É preciso também considerar que a necessidade de adequação do fundo de pensão aos limites quantitativos oficiais pode gerar distorções, com evidentes prejuizos para os associados do fundo de pensão. É o que acontece, por exemplo, na hipótese de um fundo de pensão ser obrigado a vender determinado ativo em razão de algum desenquadramento passivo, ou seja, um desenquadramento decorrente da própria valorização do ativo no qual o fundo previdenciário investiu. O próprio mercado, sabedor da situação de desenquadramento do fundo de pensão, poderá eventualmente se aproveitar de tal fato, em detrimento dos cotistas do fundo previdenciário.
\end{abstract}

Por esse motivo, os ganhos dos fundos de pensão estão limitados: quando seus ativos atingem um determinado grau de valorização, os administradores dos Fundos de Pensão são obrigados a se desfazer deles para poder reenquadrar as aplicações dos recursos dos planos de benefícios aos limites da Resolução CMN 3.792. Essa situação é ruim para os participantes, assistidos e beneficiários dos planos de benefícios e boa para agentes do mercado que comprarão aqueles ativos por preço inferior ao que poderia adquirir em situações normais.

Nessa situação, o respeito aos limites estabelecidos pode significar até mesmo uma infração ao disposto no art. 12 da Resolução CMN 3.792, que diz que o Fundo de Pensão deve gerenciar os ativos de cada plano de forma a garantir, permanentemente, o equilíbrio entre os ativos e o passivo atuarial e as outras obrigações do plano ${ }^{91}$.

\footnotetext{
${ }^{90}$ REIS, Adacir. Fundos de Pensão e Mercados de Capitais. São Paulo: Editora Peixoto Neto, 2008. P. 26.

91 Art. 12. A EFPC deve gerenciar os ativos de cada plano de forma a garantir o permanente equilíbrio econômico-financeiro entre estes ativos e o passivo atuarial e demais obrigações do plano.
} 
Haverá, dessa forma, operações que, apesar de desrespeitarem os limites da Resolução CMN 3.792, serão realizadas em nome da cautela, tendo em vista a saúde financeira dos planos administrados pelos fundos de pensão. Por outro lado, a obediência aos limites de investimento prescritos pelo mesmo diploma não dispensam o administrador da análise de risco e de retorno dos ativos aplicados.

Por esse motivo, não se pode confundir a obediência dos limites de aplicação com a prudência do administrador, sob pena de infração ao Princípio da Legalidade por se estar criando um novo tipo penal por meio de uma integração incabível e que, ainda que se estivesse tratando de uma norma penal em branco, exorbita os limites do próprio tipo penal. Nesse sentido, tem-se a lição de Heleno Cláudio Fragoso ${ }^{92}$ :

Como é óbvio, essa integração deve ser feita nos precisos limites fixados pelo preceito genérico da norma em branco, não sendo possível que um ato administrativo, por exemplo, ultrapasse o claro da lei penal sem ferir o princípio de estrita legalidade dos crimes e das penas (art. $1^{o}, C P$ ).

A Lei $\mathrm{n}^{\mathrm{o}}$ 12.618/2012, que instituiu o regime de previdência complementar para servidores públicos federais titulares de cargos efetivos foi além da previsão contida na LC 109/2001 dando ao CMN competência para, além da fixação de diretrizes, estabelecer também limites prudenciais para a aplicação de recursos dos fundos ali referidos. Demonstrando, mais uma vez, que os limites para aplicação de recursos - editados a título da regulamentação de diretrizes nos moldes do art. 9, § único, da LC 109/2001 - não se confundem com limites prudenciais para aplicação de recursos ${ }^{93}$.

\footnotetext{
${ }^{92}$ FRAGOSO, Heleno Cláudio. Lições de Direito Penal: Parte Geral. 16.ed. Rio de Janeiro: Forense, 2004. P. 93.

93 Art. 15. A aplicação dos recursos garantidores correspondentes às reservas, às provisões e aos fundos dos planos de benefícios da Funpresp-Exe, da Funpresp-Leg e da Funpresp-Jud obedecerá às diretrizes e aos limites prudenciais estabelecidos pelo Conselho Monetário Nacional (CMN).
} 
Leonardo André Paixão, Ricardo Pena Pinheiro e José Carlos Sampaio Chedeak $^{94}$, em artigo conjunto, publicado na Revista de Previdência da Faculdade de Direito da UERJ, diferenciam o que chamam de limites prudenciais e limites quantitativos e chamam atenção para a tendência legislativa em dar maior atenção para os limites prudenciais.

No momento atual, coloca-se em discussão a passagem para uma terceira fase da regulação, em que se abre o debate - à luz da evolução natural da regulação dos investimentos observada nos países desenvolvidos - a respeito da elaboração de regras prudenciais, em que os limites quantitativos perdem importância, ganhando relevo, para seleção das opções de aplicação mais adequadas, as características próprias de cada plano de benefícios administrado por entidade fechada de previdência complementar.

Em suma, criminalizar atos que não traduzem necessariamente gerir imprudentemente recursos de terceiros equivale a criar um tipo penal por meio de ato administrativo.

\subsubsection{Tipo penal aberto}

Também há de se rechaçar qualquer entendimento que julgue o tipo como uma norma penal em branco, complementada pelas normas do CMN e do Banco Central do Brasil ("Bacen"). A respeito dessas normas, Juarez Cirino dos Santos ${ }^{95}$ comenta que exprimem uma tendência do Direito Penal em transferir ao Poder Executiva a transferência de poderes punitivos.

As leis penais em branco exprimem a tendência moderna de administrativização do Direito Penal, com transferência de poderes punitivos a funcionários do Poder Executivo, ou a modalidades inferiores de atos normativos (Decreto, Resolução etc.), com os seguintes problemas:

a) primeiro, um problema político: a transferência da competência legislativa para definir a conduta proibida para o Poder Executivo, ou para níveis inferiores de atos legislativos, infringe o princípio da legalidade, como afirma um setor avançado da literatura penal - afinal, o emprego instrumental do Direito Penal para realizar políticas públicas emergenciais é inconstitucional.

\footnotetext{
${ }^{94}$ PAIXÃO, Leonardo André, et al. Regulação dos investimentos nos fundos de pensão: evolução histórica, tendências recentes e desafios regulatórios. Disponível em: $<$ http://www.previc.gov.br/central-de-conteudos/publicacoes/artigos/2005/regulacao-dosinvestimentos-nos-fundos-de-pensao.pdf >. Acesso em 24.05.2016.

${ }^{95}$ SANTOS, Juarez Cirino. Direito penal: parte geral. 2 ed. Curitiba: Lumen Juris, 2007. P. 50-51.
} 
b) segundo, um problema prático - porque a inconstitucionalidade da lei penal em branco não exclui sua eficácia concreta enquanto integrar a legislação penal: definir se o complemento posterior favorável ao autor (por exemplo, a doença foi excluída do catálogo) é retroativo ao fato realizado na vigência de complemento anterior prejudicial ao autor (na época do fato, a doença constava do catálogo).

Doutrina e jurisprudência são uníssonas ao caracterizar a gestão temerária como tipo penal aberto e não norma penal em branco, conforme se aduz da leitura do artigo de Gamil Föppel El Hireche e Gabriel Dalla Favera de Oliveira ${ }^{96}$ :

Indubitável a caracterização de tipo penal aberto no presente caso, uma vez que a lei não foi capaz de definir a conduta, mas resta a cargo do juiz fazê-lo quando da sua aplicação.

Também o Desembargador Federal Manoel De Oliveira Erhardt, em seu voto na Apelação Criminal 4.443-CE (2005.05.00.036940-8), deixa claro o seu posicionamento:

17. Pois bem, não pode prosperar a alegação de que a Resolução 1.559/88$B A C E N$, na qual se fundamentou a denúncia, foi derrogada pela Resolução 3.258/05-BACEN, ocorrendo a descriminalização da conduta dos denunciados. O tipo penal da gestão temerária não depende e complementação pelas normas do Banco Central, uma vez que não se trata de norma penal em branco. Como bem afirmou o Ministério Público Federal, em suas contra-razões, o Banco Central pode apontar indicativos de uma gestão temerária ou fraudulenta, mas não afastará a análise, caso a caso, pelo Juiz do processo criminal. O juiz terá preservada a sua independência para interpretar o tipo incriminador em face das condutas imputadas aos réus, independentemente de previsão nas normas do Banco Central (fls. 3.992).

(Grifou-se)

Com isso, aduz-se que a gestão temerária é um tipo penal que não necessita de complementação, seus conceitos se satisfazem em si próprio.

\footnotetext{
${ }^{96}$ HIRECHE, Gamil Föppel El, e OLIVEIRA, Gabriel Dalla Favera de. Notas críticas acerca da tipicidade nos delitos penais econômicos: o viés concreto de análise sobre delito de gestão temerária, previsto no art. $4^{o}$, parágrafo único, da Lei $n^{o}$ 7.492/76. Disponível em: $<$ https://d24kgseos9bn1o.cloudfront.net/editorajuspodivm/arquivos/paginas_265_297.pdf $>$ Acesso em: 30.05.2016.
} 


\subsubsection{Crime doloso}

Faz-se mister dizer que essa imprudência aqui referida não se confunde com culpa. O art. 18, II, do Código Penal apenas admite o crime a título culposo quando previsto expressamente em lei, o que não é o caso. A esse respeito, Flávio Antônio da $\mathrm{Cruz}^{97}$ tece uma poderosa crítica, para ele, a sanção pela mera violação ao dever geral de cautela não é passível de sanção sob pena de grave violação à segurança jurídica.

Temeridade é incúria, precipitação. Quando muito, a figura daria azo à chamada culpa consciente: conduta de quem sabe que assume riscos indevidos, mas acredita imprudentemente na sua capacidade (ou de outrem) de evitar o resultado lesivo. Soa difícil sustentar a figura da vontade de agir temerariamente, como se fosse uma conduta dolosa, ao menos que se desconsidere o sentido vernacular da expressão temeridade. É fato que, sob determinado aspecto, o agente que comete crime culposo, tem intenção de agir imprudentemente (vontade de dirigir a mais de 150/h), ou, quando menos, não se apercebe muito disto (culpa inconsciente).

A conduta dolosa exige a representação e a vontade, endereçada não apenas para a criação genérica de riscos (i.e., para o agir temerário), mas para fins previstos no tipo penal. E tais fins, resultados, não estão alocados no art. $4^{\circ}$. Partindo dessa premissa (que se cuide de um crime imprudente), seria aceitável, em um Estado Democrático, que o legislador tipificasse criminalmente algo como: conduzir-se temerariamente no trânsito? A resposta é negativa, pois, do contrário, haveria flagrante violação ao princípio da segurança jurídica, subjacente à regra da legalidade penal. Soa indispensável, para a configuração de um crime culposo, que o agente somente responda acaso produza resultados lesivos. A mera violação ao dever geral de cautela (sem o resultado, e sem detalhamentos) não pode ser sancionada penalmente, sob pena de grave lesão à segurança jurídica.

\subsubsection{Crime habitual}

Ainda é importante ressaltar outra característica fundamental do tipo penal de gestão temerária: trata-se de um crime habitual, que não se consubstancia em apenas um ato isolado. Nas palavras de Antônio Carlos Rodrigues da Silva ${ }^{98}$ :

${ }^{97}$ CRUZ, Flavio Antônio da. Gestão temerária, evasão de divisas e aporias. Revista Brasileira de Ciências Criminais, São Paulo, v. 18, n. 86, p.99-147, set./ out. 2010. ${ }^{98}$ SILVA, Antônio Carlos Rodrigues da. Crimes de colarinho branco. Brasília: Brasília Jurídica, 1999, p. 48. 
O referido núcleo, gerir, é predicado verbal de natureza habitual, evidenciando condutas reiterativas, repetitivas no tempo e no espaço. Gerir, significando administrar, reger e governar não se consuma com apenas um ato de gestão, de gerência, de administração ou de governo, exige, necessariamente, uma sucessão de atos apreciáveis num determinado contexto e lapso temporal. E para que se infira ser a gestão fraudulenta ou temerária, necessário se faz cotejar esses atos no bojo de uma administração, gerência ou regência

Então um mero ato equivocado na gestão de um Fundo de Pensão não é o suficiente para caracterizar o crime.

\subsubsection{Da configuração de indícios}

Leonardo Vasconcellos Rocha ${ }^{99}$ invoca a infração administrativa contida no art. 64 do Dec. 4.942/2003, alegando a sua proximidade com o art. $4^{\circ}, \S$ único, da Lei 7.492/1986, para dizer que a simples ocorrência da infração administrativa representa indícios de gestão temerária, o que gera a obrigação do órgão fiscalizador (desde 2009, com o advento da Lei 12.154, art. 55, a PREVIC assume essa posição) notificar o Ministério Público, nos termos do art. 64 da LC 109/2001.

Art. 64. O órgão fiscalizador competente, o Banco Central do Brasil, a Comissão de Valores Mobiliários ou a Secretaria da Receita Federal, constatando a existência de práticas irregulares ou indícios de crimes em entidades de previdência complementar, noticiará ao Ministério Público, enviando-lhe os documentos comprobatórios.

Parágrafo único. O sigilo de operações não poderá ser invocado como óbice à troca de informações entre os órgãos mencionados no caput, nem ao fornecimento de informações requisitadas pelo Ministério Público.

Esse posicionamento parece afrontar o Princípio da Presunção de Inocência (art. $5^{\circ}$, inciso LVII, da CRFB), pois como já visto o crime de gestão temerária é habitual, não é um mero ato de imprudência capaz de caracterizá-lo. Além disso, muitas regras administrativas não se traduzirão em normas de prudência do administrador.

99 ROCHA, Leonardo Vasconcellos. Violação às diretrizes da resolução CMN $n^{\circ}$ 3.792/2009: a necessidade de encaminhamento dos autos de infração lavrados pela PREVIC ao Ministério Público Federal. Disponível em: $<$ http://www.conteudojuridico.com.br/artigo,violacao-as-diretrizes-da-resolucao-cmn-no37922009-a-necessidade-de-encaminhamento-dos-autos-de-infracao-lavr,51411.html> Acesso em: 22.05.2016. 


\subsection{São válidos os limites instituídos pela Resolução CMN no 3.792 ?}

Talvez a questão mais importante do estudo até aqui desenvolvido reside na indagação a respeito da validade das normas regulamentadoras dos limites de aplicação dos recursos dos planos de benefícios dos Fundos de Pensão.

De acordo com o ensinamento de Carlos Ari Sundfeld ${ }^{100}$, há situações subjetivas passivas impostas pela lei e controlada pela Administração Pública - ou impostas pela Administração Pública com base da lei e por aquela controlada aos titulares - de direitos que consistem em deveres de não fazer, de fazer ou de suportar; ou seja, limites, encargos ou sujeições. A essas situações dá-se o nome de condicionamentos administrativos.

Os condicionamentos administrativos devem respeitar o conteúdo mínimo do direito ${ }^{101}$, em outras palavras, tais limites, encargos ou sujeições jamais inviabilizarão o exercício do direito que afetam.

A Resolução CMN nº 3.792 impõe situações subjetivas passivas com base na LC 109/2001 que consistem em deveres de não fazer, como não aplicar mais de uma determinada porcentagem em dado ativo. Por esse motivo, trata-se de um condicionamento administrativo. Segundo Sundfeld ${ }^{102}$ :

A proibição de certos atos - que, de outro modo, o indivíduo poderia praticar, com base na liberdade genericamente garantida pela Constituição - indica os limites dos direitos, portanto estes traduzem deveres de não fazer.

Sundfeld ${ }^{103}$ ainda explica que o ato administrativo que institui limite ao direito pode ser geral, afetando a todos que se encontrem em dada

100 SUNDFELD, Carlos Ari. Direito Administrativo Ordenador. Malheiros Editores LTDA. São Paulo, SP. 1993.

${ }^{101}$ Op. cit. P. 56.

102 Op. cit. P. 58.

${ }^{103}$ Op. cit. P. 59. 
situação jurídica. Este ato, todavia, não limita o direito de particulares, mas tão somente define concretamente os limites já estabelecidos em lei. Por esse motivo, o autor faz o seguinte esclarecimento ${ }^{104}$ :

(...) o condicionamento em si deve estar previsto e delimitado na lei, servindo o ato da Administração como mero comando complementar dela. Caso contrário (isto é, se a lei conferisse o poder indefinido de a Administração constranger os direitos dos particulares), estar-se-ia diante de delegação à autoridade administrativa de verdadeiro poder legislativo, o que violaria o princípio da separação de poderes $\left(C F\right.$, art. $\left.2^{\circ}\right)$.

A LC 109/2001, mediante a redação do $\S 1^{\circ}$ do art. $9^{\circ}$, concede ao CMN poderes para estabelecer diretrizes para aplicação dos recursos administrados pelos Fundos de Pensão. É com base nesse dispositivo que a Resolução CMN 3.792 foi editada:

Art. $9^{\circ}$ As entidades de previdência complementar constituirão reservas técnicas, provisões e fundos, de conformidade com os critérios e normas fixados pelo órgão regulador e fiscalizador.

$\S 1^{\circ}$ A aplicação dos recursos correspondentes às reservas, às provisões e aos fundos de que trata o caput será feita conforme diretrizes estabelecidas pelo Conselho Monetário Nacional.

(...)

Segundo a boa técnica interpretativa, o parágrafo primeiro, que trata da aplicação dos recursos administrados pelos Fundos de Pensão, deve ser lido de acordo com o caput do artigo, que fala sobre a constituição dos fundos.

Da leitura do caput, pode-se extrair duas interpretações: a primeira no sentido de que normas específicas criadas pelo órgão regulador e fiscalizador conduzirão a contabilidade desses itens e a segunda referente aos ativos que constituirão essas reservas técnicas, provisões e fundos.

A atividade legislativa parece ter objetivado a primeira significância para a regra que criou, conforme se aduz de diversos dispositivos da Instrução SPC n 31, como os itens 26 e 27 do Anexo A:

${ }^{104}$ Op. cit. P. 75. 
26. As provisões em caráter contingencial devem ser contabilizadas no exigível contingencial, tendo como contrapartida a conta "Constituição/Reversão de Contingência".

27. O superávit técnico do plano de benefícios, apurado nos termos estabelecidos pelo Conselho de Gestão da Previdência Complementar - CGPC, deve ser contabilizado em "Reserva de Contingência", até o limite de 25\% (vinte e cinco por cento) das "Provisões Matemáticas", e o que exceder este percentual em "Reserva Especial para Revisão de Plano".

O Decreto 4.942/2003 define como infração administrativa, no art. 63 (situado bem acima do art. 64 que prevê a infração administrativa por aplicação em desacordo com as diretrizes estabelecidas pelo CMN) o seguinte:

Art. 63. Deixar de constituir reservas técnicas, provisões e fundos, de conformidade com os critérios e normas fixados pelo Conselho de Gestão da Previdência Complementar e pela Secretaria de Previdência Complementar.

Penalidade: multa de $R \$ 20.000,00$ (vinte mil reais), podendo ser cumulada com suspensão pelo prazo de até cento e oitenta dias ou com inabilitação pelo prazo de dois a dez anos.

Esse artigo deve ser lido levando-se em consideração que o art. 55 da Lei 12.154/2009 deu à PREVIC as competências da Secretaria de Previdência Complementar. Dessa forma o caput do art. $9^{\circ}$ da LC 109/2001 trata de um primeiro momento no qual para a constituição de reservas técnicas, provisões e fundos é necessária a observância de normas prescritas pelo CGPC e pela PREVIC.

O parágrafo primeiro do art. 9 da LC 109/2001, por outro lado, estaria se referindo à segunda interpretação que se poderia dar ao seu caput: regras a sobre os ativos que constituem as reservas técnicas, provisões e fundos. Porém, diferentemente do que estabelece o caput, a competência não é para a fixação de critérios e normas, mas tão somente para a edição de diretrizes. Sendo inconstitucional (art. 5', II, CRFB) quaisquer regras que extrapolem essa competência. 
Por esse motivo, Adacir Reis ${ }^{105}$ considera inconstitucionais os sublimites impostos pela Resolução CMN 3.792, já que estariam ultrapassando os limites da norma que regulamenta:

As novas regras de governança dos fundos de pensão brasileiros, o surgimento da visão crítica do conjunto de participantes de planos de previdência complementar, o desenvolvimento do mercado de capitais, todos interagindo com um sistema financeiro que se aprimorou admiravelmente após uma sucessão impressionante de "pacotes econômicos" das décadas de 1980 e 1990, fazem-nos supor que o Brasil terá, nos próximos anos, a redução os limites quantitativos para os investimentos de recursos previdenciários, especialmente para os sublimites, os quais não condizem com o conceito de "diretrizes" para os investimentos a que se refere a própria lei federal que aponta os contornos da intervenção federal.

(Grifou-se)

A própria Resolução CMN 3.792 trata das diretrizes para os investimentos em seu Capítulo II e dos limites para a aplicação dos recursos no Capítulo VII, dando a ideia de que são temas diferentes.

Falta de elementos dentro da própria LC 109/2001 que caracterizem o que venha a "diretriz" da forma como posta pela lei - já que muitas vezes a lei faz uso de uma palavra em sentido completamente diverso da acepção que tem em nosso cotidiano.

Em razão disso, devemos nos socorrer a fontes externas à lei para descobrir o significado da palavra. Segundo a ótica geométrica, "diretriz" é a orientação de uma reta, chamada "geratriz", em movimentos sucessivos dentro de um espaço de tempo tendentes a formar um plano. Ou seja, assume um papel não de descrever contornos, mas apontar uma direção.

Essa definição nos reporta ao conceito de l'ideé diretrice. Segundo Miguel Reale ${ }^{106}$ :

Devemos prestar atenção à graduação que existe na seqüência dos elementos formadores da instituição: em primeiro lugar está a idéia objetiva diretora (lidée diretrice ou l'idée de l'oeuvre à realiser), fundamento primeiro de toda instituição

${ }^{105}$ REIS, Adacir. Fundos de Pensão e Mercados de Capitais. São Paulo: Editora Peixoto Neto, 2008. P. 31.

${ }^{106}$ REALE, Miguel. Teoria do Direito e do Estado. São Paulo, Saraiva: 2000. P. 292. 
corporativa, centro polarizador das aspirações e dos interesses individuais; em segundo lugar surge a comunhão de sentimentos e vontades, que resulta da integração do elemento humano sob o império dessa idéia diretora; em terceiro lugar, a autoridade constituída em virtude dessa integração; e, por fim, as regras de Direito como "regulamentos antecipados dos conflitos", entre os poderes dos indivíduos e os poderes da instituição.

Ou seja, uma condicionante da regra em concreto, da lei específica, assim como são as "normas gerais" da nossa Constituição. Consoante a essa ideia, no julgamento da ADI 927-MC/MS, o Ministro Carlos Velloso emprega os dois termos como sinônimos:

\footnotetext{
Penso que essas 'normas gerais' devem apresentar generalidade maior do que apresentam, de regra, as leis. Penso que 'norma geral', tal como posta na Constituição, tem o sentido de diretriz, de princípio geral. A norma geral federal, melhor será dizer nacional, seria a moldura do quadro a ser pintado pelos Estados e Municípios no âmbito de suas competências. Com propriedade, registra a professora Alice Gonzalez Borges que as "normas gerais", leis nacionais, "são necessariamente de caráter mais genérico e abstrato do que as normas locais. Constituem normas de leis, direito sobre direito, determinam parâmetros, com maior nível de generalidade e abstração, estabelecidos para que sejam desenvolvidos pela ação normativa subseqüente das ordens federais", pelo que "não são normas gerais as que se ocupem de detalhamentos, pormenores, minúcias, de modo que nada deixam à criação própria do legislador a quem se destinam, exaurindo o assunto de que tratam".

(Grifou-se)
}

Sendo norma geral das aplicações de recursos, caberia à política geral de investimentos, formulada pelo Conselho Deliberativo, integrá-la, como a norma específica integra a norma geral. Porém, na prática, sobra muito pouco espaço para tal. A cláusula de limites para o investimento da Política de Investimentos do Fundo Multinstituído por Associações do Ministério Público e da Justiça para o exercício de 2011 exemplifica bem isso:

4.8. Limites para exposição da carteira

- renda fixa: mínimo de $70 \%$ e máximo de $100 \%$ 0\% e máximo de $100 \%$ 0\% e máximo de $100 \%$ dos recursos administrados;

- renda variável: mínimo de 0\% e máximo de 20\% 0\% e máximo de $20 \% 0 \%$ e máximo de $20 \%$ dos recursos administrados;

- cotas de fundos de investimentos classificados como multimercado cujos regulamentos observem exclusivamente a legislação estabelecida pela CVM, aplicando-se os limites, requisitos e condições estabelecidos a investidores que não sejam considerados qualificados, nos termos da regulamentação da CVM (Investimentos estruturados segundo art. 37, \$2º da Res. 3.792/2009): mínimo de $0 \%$ e máximo de $10 \%$ dos recursos administrados; 
A referida cláusula é de uma frugalidade espantosa se comparada com os limites estabelecidos na Resolução CMN 3.792, mas a razão é que o $\mathrm{CMN}$, a pretexto de regulamentar as diretrizes para investimento, acabou não deixando espaço para a livre formulação da política de investimentos pelo Conselho Deliberativo. Não é razoável que o Conselho Deliberativo aprove uma política de investimentos muito complexa tendo em vista as complexas regras que já lhe são impostas por parte do CMN.

Desta forma, o tema parece nos reportar à questão suscitada na ADI 3.669-6/DF ${ }^{107}$, que em muito se assemelha à questno qual se decidiu seguindo os fundamentos abaixo expostos do voto da Ministra Cármen Lúcia:

(...) De outra parte, e como bem ressaltada na lição transcrita de José Afonso da Silva, o art. 22, inc. XXIV, da Constituição da República, ao tratar das diretrizes e bases da educação nacional, nada mais fez do que enfatizar a competência do legislador nacional em definir as normas gerais, deixando as especificidades, as singulares no âmbito de competência dos Estados e do Distrito Federal (...). (...) não seria a União que poderia fixar, pormenorizadamente, como se dar execução a todos os conteúdos educativos em cada ente estadual ou distrital.

107 ADI 3.669-6/DF. Relatora: Min. Carmen Lúcia. DJ: 29.06.2007. Disponível em: $<$ http://redir.stf.jus.br/paginadorpub/paginador.jsp?docTP=AC\&docID=469706>. Acesso em: 04.06.2016. 


\section{CONCLUSÃO}

Ao final desse estudo - ou desses estudos, caso sejam entendidos como temas individuais, intrincados por sua relação com a administração dos fundos de pensão - pode-se extrair algumas conclusões, que serão analisadas brevemente nesse tópico.

Viu-se que os Fundos de Pensão são estruturados como uma forma de aclimatação do trust ao Direito Brasileiro e que a natureza jurídica dos planos de benefícios que administra, assim como os fundos de investimento, podem ser é se condomínio.

Também foi análise desse trabalho aspectos sobre as modalidades de planos de benefícios, a natureza da previdência privada, a tributação dos fundos de pensão e a estrutura interna da administração; aspectos importantes para dar um panorama geral sobre o tema e necessários para a atividade de administração.

No Capítulo 3 expôs-se que os administradores de Fundos de Pensão respondem pessoalmente e objetivamente por infração à legislação tributária.

Aplicam-se aos administradores dos Fundos de Pensão as regras previstas na Lei 6.404/76 como deveres fiduciários dos administradores em razão de uma leitura sistemática do sistema de previdência privada, não podendo tratar a administração de Sociedades Seguradas de forma mais sérias do que a administração de Fundos de Pensão.

Também estudamos que deveres fiduciários são esses e os casos em que essas operações serão consideradas transações entre partes relacionadas, apontando para o acolhimento do conceito americano de intrinsic fairness test para a análise do Dever de Diligência em cada uma delas. 
Quanto à responsabilidade civil dos administradores, esta será, via de regra, subjetiva, devendo-se atentar para o fato de que o administrador responsável por uma tarefa é presumidamente culpado por danos advindo dela.

Porém, quando se tratar de responsabilidade dos administradores por desobediência à regras e padrões de conduta esperados pelos participantes, a responsabilidade será objetiva devido à aplicação do Código de Defesa do Consumidor em tais relações.

A desconsideração da personalidade jurídica dos Fundos de Pensão pode atingir inclusive os participantes em função do seu papel fiduciário na estrutura dos Fundos de Pensão.

A responsabilidade administrativa dos administradores segue, de acordo com o entendimento da CGPC, a mesma regra da responsabilidade civil, sendo subjetiva, e é aplicável a qualquer descumprimento de normas das leis e regulamentos pertinentes à previdência complementar.

Os participantes e instituidores dos Fundos de Pensão, em razão de serem agentes fiduciários, devem observar os padrões de conduta destinados aos administradores.

A Resolução CMN 3.792 surgiu com o propósito de disciplinar as diretrizes para aplicação de recursos administrados pelos Fundos de Pensão. Seus limites são minuciosos e complexos.

Como consequência pelo descumprimento de quaisquer dessas normas, há punição em âmbito administrativo e, para alguns, possibilidade de punição na esfera penal.

No que concerne $\hat{a}$ esfera penal, a criminalização pelos descumprimentos das normas da Resolução CMN 3.792 ocorre, para alguns, sob a égide do tipo de gestão temerária. 
Esse entendimento não prospera pelas seguintes razões: o referido tipo penal é um tipo penal aberto e não uma norma penal em branco, além disso, para que se configure a gestão temerária, é necessário demonstrar a habitualidade da conduta e a, temeridade, elemento essencial do tipo, não se confunde com a aplicação fora dos limites exigidos: muitas vezes um desenquadramento pode ser realizado por prudência.

De resto, a própria Resolução CMN 3.792 parece extrapolar a competência regulamentar dispensada ao $\mathrm{CMN}$ ao estabelecer normas tão meticulosas quando o art. 9, $\S 1^{\circ}$, da LC 109/2001 estabelece que a autarquia deverá fixar diretrizes para aplicação dos recursos.

Nesse caso, seria forçoso concluir pela inconstitucionalidade de algumas regras da Resolução CMN 3.792. 


\section{BIBLIOGRAFIA}

ALONSO, Félix Ruiz. Os fundos de investimento. Condomínios mobiliários. Revista da Faculdade de Direito, Universidade de São Paulo, [S.1.], v. 66, p. 223-271, jan. 1971. ISSN 2318-8235. Disponível em: <http://www.revistas.usp.br/rfdusp/article/view/66628>. Acesso em 25.03.2016.

BITENCOURT, Cezar Roberto; BREDA, Juliano. Crimes Contra o Sistema Financeiro Nacional \& Contra o Mercado de Capitais. Rio de Janeiro: Lumen Juris, 2011.

CRUZ, Flavio Antônio da. Gestão temerária, evasão de divisas e aporias. Revista Brasileira de Ciências Criminais. São Paulo, v. 18, n. 86, p.99-147, set./ out. 2010.

DINIZ, Gustavo Saad. Responsabilidade do administrador de entidades fechadas de previdência complementar. Revista de Informação Legislativa. Brasília, jul/set 2011.Pág. 71-80.

DOTTA, Ricardo Montenegro. A responsabilidade dos administradores de fundos de investimentos no novo código civil: uma abordagem da indústria dos fundos de investimento, voltada para a natureza da responsabilidade de seus administradores, sob a ótica dos novos princípios orientadores do direito privado e da regulamentação do setor. São Paulo: Textonovo, 2005.

EIZIRIK, Nelson. A lei das S/A comentada: artigos 121 a 188. São Paulo: Quartier Latin, 2011. v.2.

FREIRE, Alonso. $O$ Pêndulo de Posner. Disponível em: <http://revistapensamentojuridico.fadisp.com.br/ojs/index.php/pensamentoj uridico/article/download/21/37>. Acesso em: 22.05.2016.

FREITAS, Ricardo de Santos. Natureza jurídica dos fundos de investimento. São Paulo: Quartier Latin, 2006. 
FRAGOSO, Heleno Cláudio. Lições de Direito Penal: Parte Geral. 16.ed. Rio de Janeiro: Forense, 2004.

GABAS, Carlos Eduardo. Aspectos Gerais da Gestão dos Fundos de Pensão. Disponível em: <http://www.previc.gov.br/central-deconteudos/publicacoes/artigos/2008/aspectos-gerais-da-gestao-dos-fundosde-

pensao.pdf/@@download/file/Aspectos\%20Gerais\%20da\%20Gest\%C3\%A 3o\%20dos\%20Fundos\%20de\%20Pens\%C3\%A3o.pdf> Acesso em 24.05.2016.

GOMES, Orlando. Contratos. Rio de Janeiro: Forense, 1977. . Direitos reais. Rio de Janeiro: Forense, 2002.

HIRECHE, Gamil Föppel El, e OLIVEIRA, Gabriel Dalla Favera de. Notas críticas acerca da tipicidade nos delitos penais econômicos: o viés concreto de análise sobre delito de gestão temerária, previsto no art. $4^{o}$, parágrafo único, $d a$ Lei $n^{o}$ 7.492/76. Disponível em: $<$ https://d24kgseos9bn1o.cloudfront.net/editorajuspodivm/arquivos/paginas _265_297.pdf> Acesso em: 30.05.2016.

HUDSON, Alastair. Ocupational Pension Funds. Disponível em: <http://www.alastairhudson.com/trustslaw/pensions.pdf>. Em 04.05.2016.

LEITE, Marcia Lopes. A responsabilidade civil e administrativa dos administradores de fundos de pensão. Disponível em: < http://dspace.idp.edu.br:8080/xmlui/bitstream/handle/123456789/327/Mono grafia_M\%C3\%A9rcia\%20Lopes\%20Leite.pdf?sequence=1>. $\quad$ Acesso: 16.05.2016.

LIMA, Iara Menezes. Métodos Clássicos de Interpretação no Direito Constitucional. Disponível em 
<http://www.pos.direito.ufmg.br/rbepdocs/092065098.pdf>. Acesso em 24.05.2016.

MACHADO, Brandão. Estudos Sobre o Imposto de Renda (Em Memória de Henry Tilbery). Coordenação: Ives Gandra Martins. Editora Resenha Tributária Ltda.: São Paulo, Julho de 1994.

MACHADO, Hugo de Brito. Comentários ao Código Tributário Nacional. $2^{a}$ ed. Atlas, 2007.

MAIMONI, Alexandre Brandão. A natureza jurídica dos fundos de pensão dos servidores públicos. Disponível em: < https://jus.com.br/artigos/5818/anatureza-juridica-dos-fundos-de-pensao-dos-servidores-publicos/2>. Acesso em 23.05.2016.

MARTINS, Danilo Ribeiro Miranda. O conflito de interesses no Sistema Previdenciário Complementar. Disponível em: <http://bdjur.stj.jus.br/jspui/bitstream/2011/46270/conflito_\%20interesses_ sistema_martins.pdf>. Acesso em: 04 de abril de 2016.

OLIVEIRA, Leonardo Henrique Mudim Moraes. Crimes de gestão fraudulenta e gestão temerária em Instituição Financeira. Disponível em: <http://www2.senado.leg.br/bdsf/bitstream/handle/id/502/r143-

05.PDF?sequence=4> Acesso 22.05.2016.

OLIVEIRA, Ricardo Mariz. Fundamentos do Imposto de Renda. São Paulo: Quartier Latin, 2008.

PAES, Eduardo Sabo. Fundações e Entidades de Interesse Social. Ed. Brasília Jurídica, $3^{\text {a }}$ edição.

PAIXÃO, Leonardo André, et al. Regulação dos investimentos nos fundos de pensão: evolução histórica, tendências recentes e desafios regulatórios. Disponível em: <http://www.previc.gov.br/central-de- 
conteudos/publicacoes/artigos/2005/regulacao-dos-investimentos-nosfundos-de-pensao.pdf >. Acesso em 24.05.2016.

PEREIRA, Caio Mário da Silva. Responsabilidade civil. Rio de Janeiro: Forense, 2001.

PEDREIRA, José Luiz Bulhões, e FILHO, Alfredo Lamy (cord.). Direito das Companhias. Editora Forense. 2009.

REALE, Miguel. Teoria do Direito e do Estado. São Paulo, Saraiva.

REIS, Adacir. Curso Básico de Previdência Complementar. Editora Revista dos Tribunais: 2012, São Paulo.

(cord.). Fundos de Pensão e Mercados de Capitais. São Paulo: Editora Peixoto Neto, 2008.

ROCHA, Leonardo Vasconcellos. Violação às diretrizes da resolução CMN $n^{o}$ 3.792/2009: a necessidade de encaminhamento dos autos de infração lavrados pela PREVIC ao Ministério Público Federal. Disponível em: <http://www.conteudojuridico.com.br/artigo,violacao-as-diretrizes-daresolucao-cmn-no-37922009-a-necessidade-de-encaminhamento-dos-autosde-infracao-lavr,51411.html> Acesso em: 22.05.2016.

ROMITA, Arion Sayão. Estrutura da relação de previdência privada: entidades fechadas. Síntese Trabalhista, Porto Alegre, v 13, n 154, p 5-9, mar. 2002.

SANTOS, Juarez Cirino. Direito penal: parte geral. 2 ed. Curitiba: Lumen Juris, 2007.

SANTOS, Raquel do Amaral de Oliveira. Trust: Das origens à aceitação pelos países de direito romano-germânico. Disponível em: <http://www.dominiopublico.gov.br/download/teste/arqs/cp086499.pdf〉. Acesso em: 23.05.2016. 
SILVA, Antônio Carlos Rodrigues da. Crimes de colarinho branco. Brasília: Brasília Jurídica, 1999, p. 48.

SPINELLI, Luis Felipe. Conflito de Interesses na Administração da Sociedade Anônima. São Paulo: Malheiros Editores, 2012.

STF. ADI 3.669-6/DF. Relatora: Min. Carmen Lúcia. DJ: 29.06.2007.

Disponível em:

$<$ http://redir.stf.jus.br/paginadorpub/paginador.jsp?docTP=AC\&docID=469 706>. Acesso em: 04.06.2016.

STJ. REsp: 1266666 SP 2009/0196940-9, Relator: Ministra NANCY ANDRIGHI, Data de Julgamento: 09/08/2011, T3 - TERCEIRA TURMA, Data de Publicação: DJe 25/08/2011.

STJ - REsp: 1306333 CE 2011/0183487-0, Relator: Ministro OG FERNANDES, Data de Julgamento: 07/08/2014, T2 - SEGUNDA TURMA, Data de Publicação: DJe 19/08/2014.

SUNDFELD, Carlos Ari. Direito Administrativo Ordenador. Malheiros Editores LTDA. São Paulo, SP. 1993.

TRF-1 - RSE: 6371 AP 0006371-75.2010.4.01.3100, Relator: DESEMBARGADOR FEDERAL I'TALO FIORAVANTI SABO MENDES, Data de Julgamento: 26/03/2013, QUARTA TURMA, Data de Publicação: e-DJF1 p.315 de 19/04/2013.

TRF-5. APELAÇÃO EM MANDADO DE SEGURANÇA $n^{\circ}$ 96056/PE(2001.83.00.023913-0), Relator: Desembargador Élio Siqueira. Segunda Turma do TRF-5. Disponível em: <http://www.abrapp.org.br/MandadoSegurancaColetiva/ACORDAO_MS_ 00239133020014058300_Recife.pdf>. Acesso em 08.05.2016.

TZU, Sun. A Arte da Guerra. Coleção Leitura. Rio de Janeiro: Editora Paz e Terra, 1996. 
VASQUEZ, Jean Luiz Souza. A Sociedade de Propósito Específico na Parceria Público- Privada: Uma Análise de Direito Societário. Disponível em:

〈http://www.dominiopublico.gov.br/download/teste/arqs/cp119788.pdf >. Acesso em: 29.05.2016.

VENOSA, Sílvio de Salvo. Direito Civil: responsabilidade civil: v. 4. 10. ed. São Paulo: Atlas, 2010.

WEINTRAUB, Arthur Bragança Vasconcellos. Responsabilidade dos Administradores de Fundos de Pensão. 1. ed. São Paulo: Juarez de Oliveira, 2004. 